\title{
Effect of Faulting on Ground-Water Movement in the Death Valley Region, Nevada and California
}

\author{
by Claudia C. Faunt
}

U.S. GEOLOGICAL SURVEY

MASTER

Water-Resources Investigations Rebort 95-4132

\author{
DISCLAIMER
}

This report was prepared as an account of work sponsored by an agency of the United States Government. Neither the United States Government nor any agency thereof, nor any of their employees, makes any warranty, express or implied, or assumes any legal liability or responsibility for the accuracy, completeness, or usefulness of any information, apparatus, product, or process disclosed, or represents that its use would not infringe privately owned rights. Refer-

Prepared in cooperation with the

NEVADA OPERATIONS OFFICE ence herein to any specific commercial product, process, or service by trade name, trademark, manufacturer, or otherwise does not necessarily constitute or imply its endorsement, recommendation, or favoring by the United States Government or any agency thereof. The views and opinions of authors expressed herein do not necessarily state or reflect those of the United States Government or any agency thereof.

U.S. DEPARTMENT OF ENERGY, under

Interagency Agreement DE-Al08-92NV10874

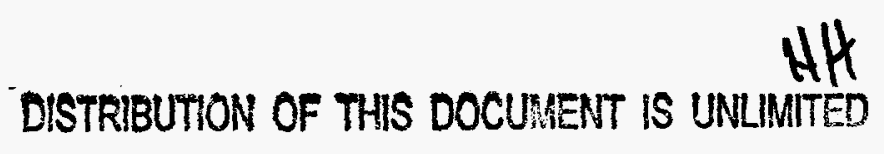

Denver, Colorado

1997

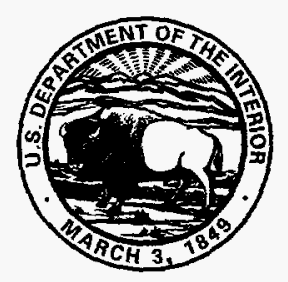




\title{
U.S. DEPARTMENT OF THE INTERIOR \\ BRUCE BABBITT, Secretary
}

\author{
U.S. GEOLOGICAL SURVEY
}

Mark Schaefer, Acting Director

The use of firm, trade, and brand names in this report is for identification purposes only and does not constitute endorsement by the U.S. Geological Survey.

For additional information write to:

Chief, Hydrologic Investigations Program

Yucca Mountain Project Branch

U.S. Geological Survey

Box 25046, Mail Stop 421

Denver Federal Center

Denver, CO 80225-0046
Copies of this report can be purchased from:

U.S. Geological Survey

Information Services

Box 25286

Federal Center

Denver, CO 80225 


\section{DISCLAIMER}

Portions of this document may be illegible electronic image products. Images are produced from the best available original document. 


\section{CONTENTS}

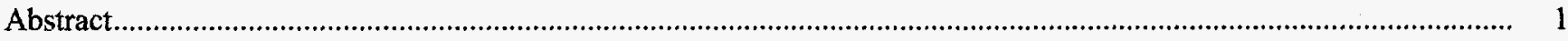

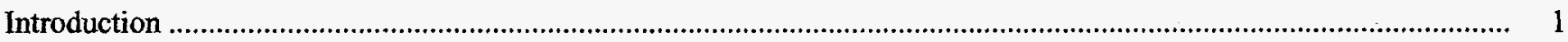

Purpose and Scope

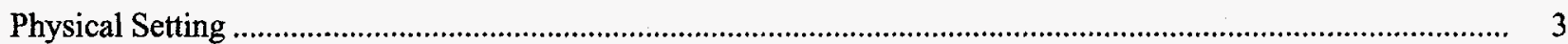

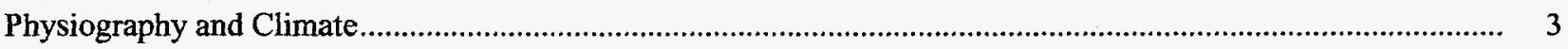

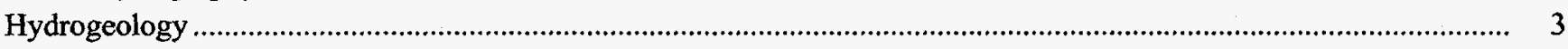

Distribution and Character of Geologic Units and Geologic Structure................................................................. 3

Definition and Distribution of Hydrogeologic Units ........................................................................................ 7

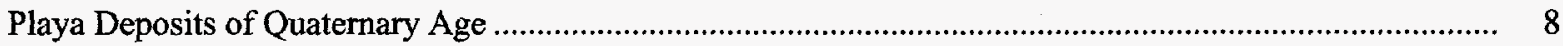

Valley Fill of Quaternary-Tertiary Age........................................................................................ 9

Volcanic Rocks of Quaternary-Tertiary Age ........................................................................................ 10

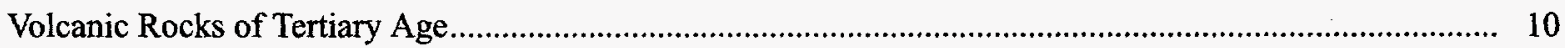

Volcanic and Volcaniclastic Rocks of Tertiary Age........................................................................... 10

Granitic Rocks of Tertiary-Late Jurassic Age ........................................................................................... 10

Sedimentary and Metavolcanic Rocks of Mesozoic Age .......................................................................... 11

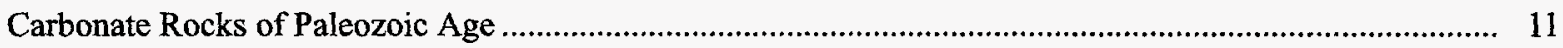

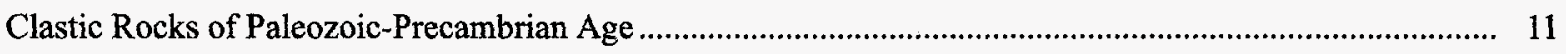

Igneous and Metamorphic Rocks of Precambrian Age .......................................................................... 11

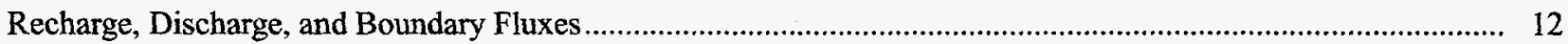

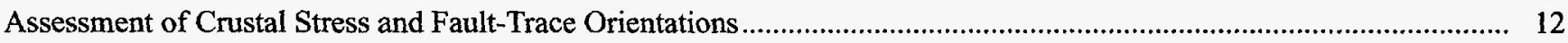

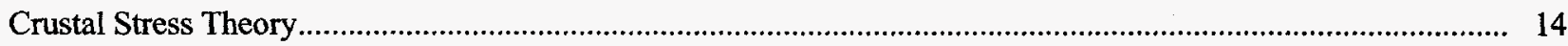

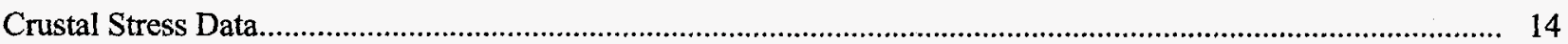

Methods of Crustal Stress Measurement .......................................................................................................... 14

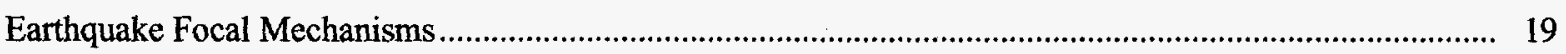

Direct (In-Place) Stress Measurements .............................................................................................. 19

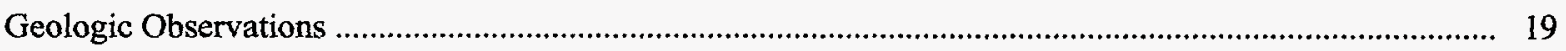

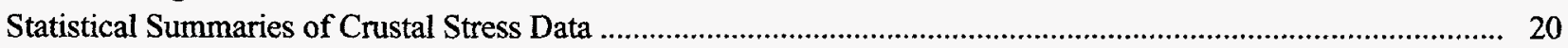

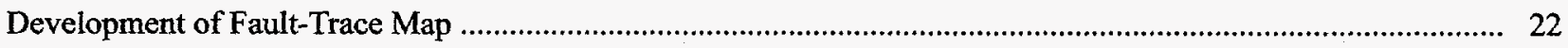

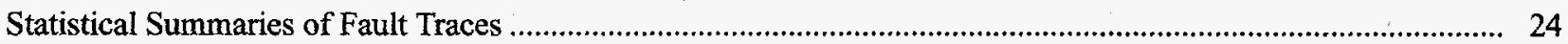

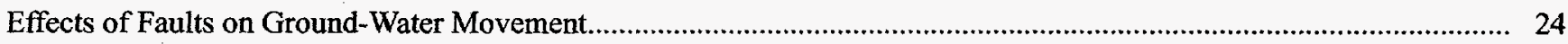

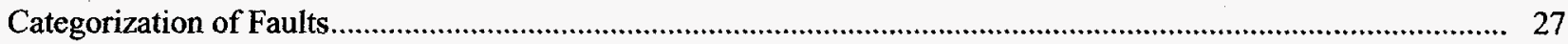

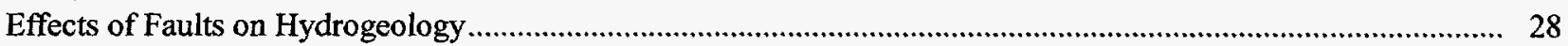

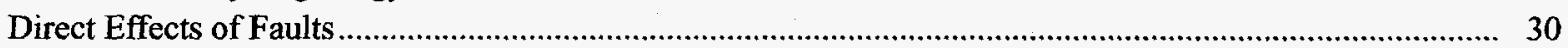

Indirect Effects of Faults ................................................................................................................... 31

Relation of Hydraulic Properties to Depth and Faulting in the Death Valley Region........................................ 32

Examples of Faults Affecting the Hydrogeology in the Death Valley Region...................................................... 34

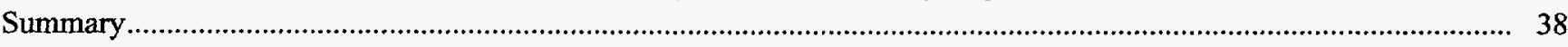

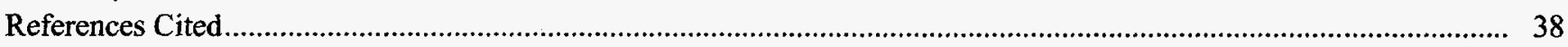

\section{PLATE}

[Plate is in pocket]

1. Classification of faults in the Death Valley region 


\section{FIGURES}

1-3. Maps showing:

1. Geographic features of the Death Valley region

2. Major structural features of the Death Valley region and vicinity ........................................................ 5

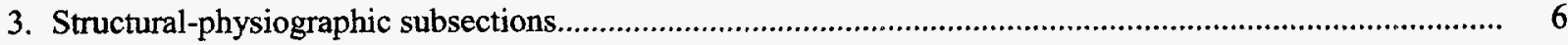

4. Block diagram showing observed configurations of ground-water flow in the Great Basin ................................. 8

5. Map showing directions of ground-water flux into the Death Valley ground-water basin .................................. 13

6. Map showing geographic distribution of minimum horizontal principal stress axis.......................................... 18

7. Rose diagrams of minimum horizontal principal stress axes for different crustal stress measurement methods.

8. Rose diagrams of minimum horizontal principal stress axes for the structural-physiographic subsections

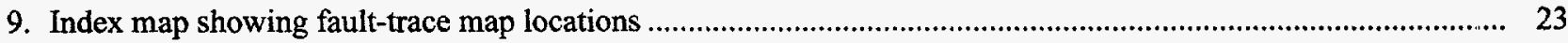

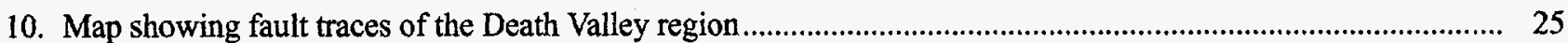

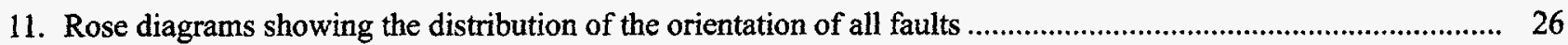

12. Flow chart showing methods used to process fault data ............................................................................... 27

13-16. Diagrams showing:

13. Orientation of mechanical state of faults using the regional average minimum horizontal principal stress axis

14. Stress model for each subsection including azimuth for the minimum horizontal principal stress axis

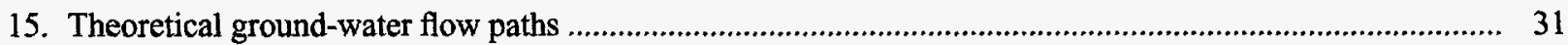

16. Theoretical ground-water flow variations in relation to faults................................................................. 32

17. Map showing Quaternary faults and epicenters for earthquakes occurring from August 1978 through December 1986 in the southern Great Basin ................................................................................. 33

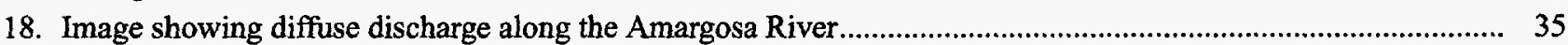

19. Schematic diagram showing structural control on ground-water flow near Salt Creek ...................................... 36

20. Map showing relative location of springs to lineations and possible faults in Ash Meadows and vicinity

\section{TABLES}

1. Estimated hydraulic conductivity of hydrogeologic units in the Death Valley region.

2. Compilation of the azimuth of the minimum horizontal principal stress axis in and around the Death Valley region

3. Statistical summaries of the orientation of minimum horizontal principal stress in the Death Valley region for different crustal stress measurement methods.

4. Statistical summaries of the orientation of minimum horizontal principal stress for the structural-physiographic subsections.

5. Orientation of fault traces 
CONVERSION FACTORS, VERTICAL DATUM, AND ABBREVIATIONS

For use of readers who prefer to use U.S. customary units, conversion factors for terms used in this report are listed below.

\begin{tabular}{rll}
\hline Multiply & \multicolumn{1}{c}{ By } & To obtain \\
\hline & Length & \\
millimeter $(\mathrm{mm})$ & 0.03937 & inch \\
meter $(\mathrm{m})$ & 3.281 & foot \\
kilometer $(\mathrm{km})$ & 0.6214 & mile \\
& Area & \\
square kilometer $\left(\mathrm{km}^{2}\right)$ & 0.3861 & square mile $\left(\mathrm{mi}^{2}\right)$ \\
& Temperature & \\
& $9 / 5\left({ }^{\circ} \mathrm{C}\right)+32={ }^{\circ} \mathrm{F}$ & degree Fahrenheit $\left({ }^{\circ} \mathrm{F}\right)$ \\
\hline
\end{tabular}

Sea level: In this report, "sea level" refers to the National Geodetic Vertical Datum of 1929 (NGVD of 1929)-a geodetic datum derived from a general adjustment of the first-order level nets of both the United States and Canada, formerly called Sea Level Datum of 1929. 


\title{
Effect of Faulting on Ground-Water Movement in the Death Valley Region, Nevada and California
}

\author{
By Claudia C. Faunt
}

\begin{abstract}
This study characterizes the hydrogeologic system of the Death Valley region, an area covering approximately 100,000 square kilometers. The study also characterizes the effects of faults on ground-water movement in the Death Valley region by synthesizing crustal stress, fracture mechanics, and structural geologic data. The geologic conditions are typical of the Basin and Range Province; a variety of sedimentary and igneous intrusive and extrusive rocks have been subjected to both compressional and extensional deformation. Faulting and associated fracturing is pervasive and greatly affects ground-water flow patterns. Faults may become preferred conduits or barriers to flow depending on whether they are in relative tension, compression, or shear and other factors such as the degree of dislocations of geologic units caused by faulting, the rock types involved, the fault zone materials, and the depth below the surface.

The current crustal stress field was combined with fault orientations to predict potential effects of faults on the regional groundwater flow regime. Numerous examples of faultcontrolled ground-water flow exist within the study area. Hydrologic data provided an independent method for checking some of the assumptions concerning preferential flow paths.
\end{abstract}

\section{INTRODUCTION}

Yucca Mountain, in southern Nevada (fig. 1), is being considered as a potential site for the storage of high-level nuclear waste in an underground mined geologic repository. Because of the potential for radionuclides to be transported by ground water from the repository to the accessible environment, studies are being conducted to characterize the Death Valley regional flow system of which Yucca Mountain is a part (Bedinger and others, 1989c). Analysis of the regional flow system at Yucca Mountain will help to define the boundary conditions of the hydrologic system at the repository site. This study is a part of the hydrologic evaluation of the region in and around Yucca Mountain.

This investigation was conducted in cooperation with the Department of Energy, under Interagency Agreement DE-AI08-92NV10874, as part of the Yucca Mountain Site Characterization Project. Information in this report is presented as part of ongoing investigations by the U.S. Geological Survey (USGS) regarding the hydrologic and geologic suitability of Yucca Mountain as a nuclear waste storage site.

Water-bearing properties, areal distribution, geologic structure, and composition of rocks control the occurrence, movement, and chemistry of ground water. Therefore, an understanding of the general geology of an area and the hydrologic framework is necessary to properly interpret and understand the regional ground-water flow system.

\section{Purpose and Scope}

This report characterizes the effects of faults on ground-water flow in the Death Valley region by synthesizing crustal stress, fracture mechanics, and structural geologic data. From these data, the hydraulic characteristics of geologic structures in the region and the effects of faulting on regional groundwater flow patterns can be inferred. This work is being undertaken to complement the construction of a regional hydrogeologic framework for a regional ground-water flow model. 


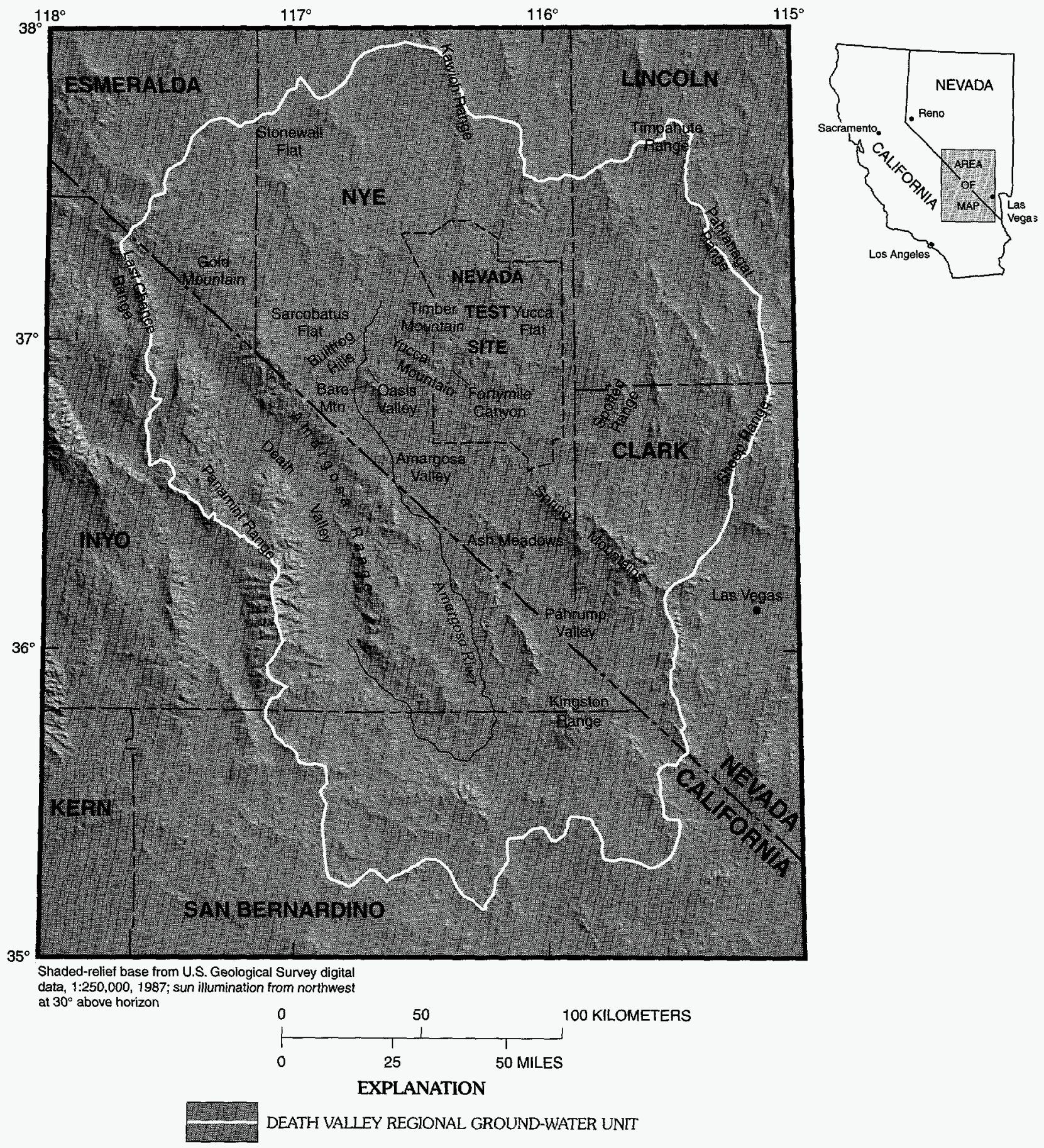

Figure 1. Geographic features of the Death Valley region. 


\section{Physical Setting}

The study area is bounded by lat $35^{\circ} \mathrm{N}$., long $115^{\circ} \mathrm{W}$, and lat $38^{\circ} \mathrm{N}$, long $118^{\circ} \mathrm{W}$., encompassing the Death Valley ground-water basin (fig. 1), as defined by Bedinger and others (1989c). The geographic extent of the study area is shown in figure 1 and includes about $100,000 \mathrm{~km}^{2}$. The study area is referred to as the Death Valley region.

The Death Valley region includes Las Vegas, Nevada, and several large, prominent valleys: Amargosa Valley, Pahrump Valley, and Death Valley (fig. 1). The region also includes several major mountain ranges including the Panamint Range, the Spring Mountains, the Sheep Range, the Kawich Range, the Kingston Range, the Pahranagat Range, the Timpahute Range, and the Last Chance Range (fig. 1). Yucca Mountain, site of a potential high-level radioactive-waste repository, is approximately at the geographic center of the study area on the western boundary of the Nevada Test Site (NTS) (fig. 1). Most of the land in the study area is owned by the U.S. Government and is administered by various Federal agencies.

\section{Physiography and Climate}

The landscapes of the Death Valley region are visually dominated by isolated mountain ranges rising abruptly from broad, alluvium-filled desert basins. These ranges occupy about 25 percent of the landscape in the study area. The remainder of the landscape is occupied by broad, intermontane basins formed from tectonically down-dropped grabens. The basins are filled with alluvium, which gently slopes from the valley floors to the bordering mountain ranges. This slope, known as the piedmont, is formed from coalescing alluvial fans issuing from steep mountain canyons (Peterson, 1981).

The valley bottoms or basins are local depositional centers that usually are marked by playa lakes, which act as catchments for surface-water runoff (Grose and Smith, 1989). The Amargosa River, an intermittent stream whose basin covers about $15,000 \mathrm{~km}^{2}$, discharges into the southern end of Death Valley (fig. 1) (Hunt and others, 1966). However, most of these basins seldom contain standing water. Playas, or dry lakes, and alluvial flats constitute about 10 percent of the study area.
Numerous playas in these closed basins contain saline deposits, the result of evaporation of surface water and shallow ground water from the playa surface. Some of the playas affected by Quaternary faulting contain springs where ground water is forced to the surface by juxtaposed lake sediments (Bedinger and others, 1989a, 1989c).

The study area has a semiarid to arid climate and is located within the southern Great Basin, a subprovince of the Basin and Range physiographic province. Elevations range from $86 \mathrm{~m}$ below sea level at Death Valley to 3,600 m above sea level at Mount Charleston (not shown) in the Spring Mountains (fig. 1); as a result, the Death Valley region includes a great variety of climatic regimes and associated recharge/discharge conditions. Late Cenozoic-age tectonism and faulting account for much of the topographic relief (Grose and Smith, 1989).

\section{HYDROGEOLOGY}

Numerical simulation of regional ground-water movement requires information about regional geology, the distribution of hydraulic properties, and hydrologic boundary conditions. This information forms the geologic and hydrogeologic framework for understanding the ground-water flow system. Conceptualization of a ground-water flow system requires the identification and assessment of system elements, including: (1) distribution and character of geologic units and geologic structures; (2) definition and distribution of hydrologic properties of hydrogeologic units; and (3) estimates for recharge, discharge, and boundary fluxes.

\section{Distribution and Character of Geologic Units and Geologic Structure}

The Death Valley region has a long and active geologic history, including intermittent marine and non-marine sedimentation, large-scale compressive deformation, plutonism, volcanism, and extensional tectonics (Mifflin, 1988). Consequently, diverse rock types, ages, and deformational structures often are juxtaposed to each other. As a result, subsurface conditions are variable and complex. Knowledge of the geologic diversity beneath alluvial basins is often indirect in much of the region. 
The study area consists of Precambrian- and Cambrian-age clastic and crystalline rocks; Paleozoicage clastic and carbonate rocks; clastic and intrusive rocks of Mesozoic age; varied fluvial, paludal, pond, and playa sedimentary rocks of Pliocene age; volcanic rocks and alluvium of 'Tertiary age; and alluvium, colluvium, and eolian deposits of Quaternary age (Waddell, 1982). The Death Valley region has been altered by several episodes of tectonic activity (fig. 2). Structural and tectonic features of the study area reveal a long, complex, tectonic evolution. Literature on specialized studies is voluminous; yet only a few integrative, comprehensive, and summary papers exist (Grose and Smith, 1989). Burchfiel and Davis (1981) discussed tectonic regimes in the California area, and Stewart (1978) discussed the tectonics of the Nevada part of the region concisely and comprehensively using structural mechanics principles. Grose and Smith (1989) described this geologic complexity and offered insight into the hydrogeologic and tectonic controls on ground-water flow. Most of the study area has undergone deformation and some parts have been nearly continuously tectonically active (Grose and Smith, 1989). The structural features and faulting are a result of the complex interaction of the North American and Pacific plates (Smith and Sbar, 1974). Combinations of normal, reverse, and strike-slip faulting and folding episodes have resulted in complex distributions of rocks.

Metamorphic basement rocks of Precambrian age were deposited approximately 1.7 to 1.4 billion years ago as a result of geosynclinal, orogenic, and magmatic arc-type terranes. Sedimentation patterns also were influenced by the northeast-trending Transcontinental arch. During the late Precambrian, the study area underwent a period of continental margin rifting (Grose and Smith, 1989).

From the late Precambrian to the Devonian, continental quartzites and siltstones were deposited with an additional $8,000 \mathrm{~m}$ of carbonate and calcareous shales in a westward-thickening clastic and carbonate wedge sequence. The first major Phanerozoic tectonic event in the Death Valley region was the Antler orogeny. During the Antler orogeny (Devonian to Mississippian), a thick wedge of clastic rocks derived from adjacent highlands was deposited in a northeast-trending basin. This basin now is defined by the location of the Eleana Formation, which contains dominantly relatively impermeable argillites and shales. This orogeny also caused eastward thrusting of more than $100 \mathrm{~km}$ of deep-ocean shales, chert, and volcanic rocks. The leading edge of the Roberts Mountain thrust is in the northwestern part of the Death Valley region (Grose and Smith, 1989).

During the Carboniferous, after the Antler orogeny and before the Sonoma orogeny, rifting and compression occurred, creating localized basins with variable sedimentary rocks. These were deposited as interbeds within an otherwise uninterrupted deposition of carbonates. The Sonoma orogeny (Late Permian and Early Triassic) resulted in a period of deep-ocean siliceous rock and volcanic rock deposition, followed by overthrusting. Structures associated with the Sonoma orogeny occur mainly in the northwestern part of the Death Valley region (fig. 3). These events created scattered terranes of lower Mesozoic metasedimentary and metavolcanic rocks. The Sevier orogeny (Middle Jurassic and Late Cretaceous) was highlighted by north-south-trending thrust faulting (including the Pahranagat, Gass Peak, Lee Canyon, and Keystone thrusts within this study area) and simultaneous intrusions of granites of Mesozoic age throughout the Death Valley region (Grose and Smith, 1989).

In contrast to earlier compressional tectonism, regional uplift, erosion, volcanism, and extension occurred in the Tertiary. As a result, the Death Valley region now includes numerous north-south-trending valleys containing continental alluvial, paludal, and colluvial materials that are interstratified with volcanic lava flows, tuffs, and tuffaceous sediments. The study area also underwent a period of intense volcanism during the late Tertiary and was heavily scarred by massive volcano-tectonic and caldera depressions and voluminous ash flows.

From the late Tertiary through the Holocene, volcanic activity diminished, and large shear zones, which cross the study area from the northwest to the southeast, developed. Meanwhile, water levels in pluvial lakes rose and fell in response to climate fluctuations, and deposition of valley-fill materials continued.

Superimposed on the earlier structural features, and dominating the topographic and physiographic features of the study area, is a basin and range type of deformation and associated volcanism (Grose and Smith, 1989). According to Dickinson and Snyder (1979), basin and range deformation occurred in two phases. The first phase began during late Eocene and ended during middle Miocene and is associated with 


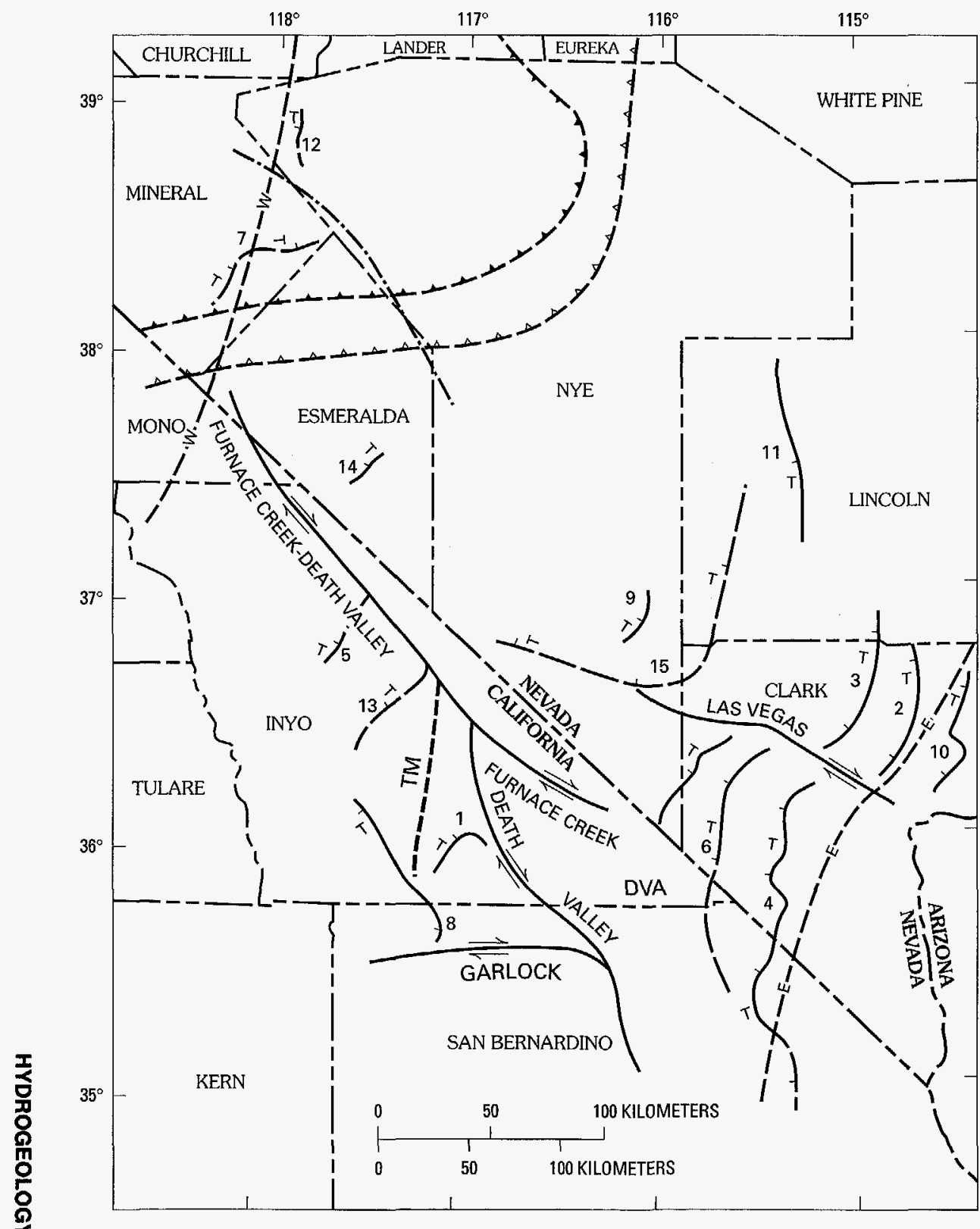

\section{EXPLANATION}

- -E- - EAST LIMIT OF MIOGEOSYNCLINAL SHELF; WEST LIMIT OF CRATONAL PLATFORM-Late Precambrian to Late Cretaceous

- W- - WEST LIMIT OF MIOGEOSYNCLINAL SHELF; WEST LIMIT OF GRANITIC ROCKS OF CONTINENTAL CRATON-Early and Middle Proterozoic

$\wedge-1$ - ROBERTS MOUNTAIN THRUST FAULT (LEADING EDGE) OF ANTLER OROGENY—Late Devontan to Early Mississippian. Sawteeth on upper plate

$\llcorner\perp \perp$ GOLCONDA THRUST FAULT (LEADING EDGE) OF SONOMA OROGENY-Late Permian to Early Triassic. Sawteeth on upper plate

$10, T$ MAJOR THRUST FAULTS OF SEVIER OROGENY, CRETACEOUS, AND OLDER UNNAMED THRUSTING EVENTS

1 Butte Valley 9 Mine Montain and CP Hills

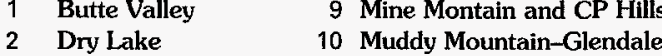

3 Gry Lake $\quad 10$ Muddy Mountain-Ge

4 Keystone 12 Paradise

5 Last Chance 13 Racetrack

6 Lee Canyon 14 Silver Peak

15 Spotted Range

8 Leyton Well

— MAJOR STRIKE-SLIP FAULTS-Cenozoic. Arrows indicate direction of relative movement

- TM - SHEAR ZONE-TM, Towne Pass-Manly Pass

- - - - NORTHEAST MARGIN OF WALKER LANE WHERE RELATIVELY WELL DEFINED

DVA DEATH VALLEY AULACOGEN AREA-Late Precambrian

Figure 2. Major structural features of the Death Valley region and vicinity (modified from Bedinger and others, 1989a). 


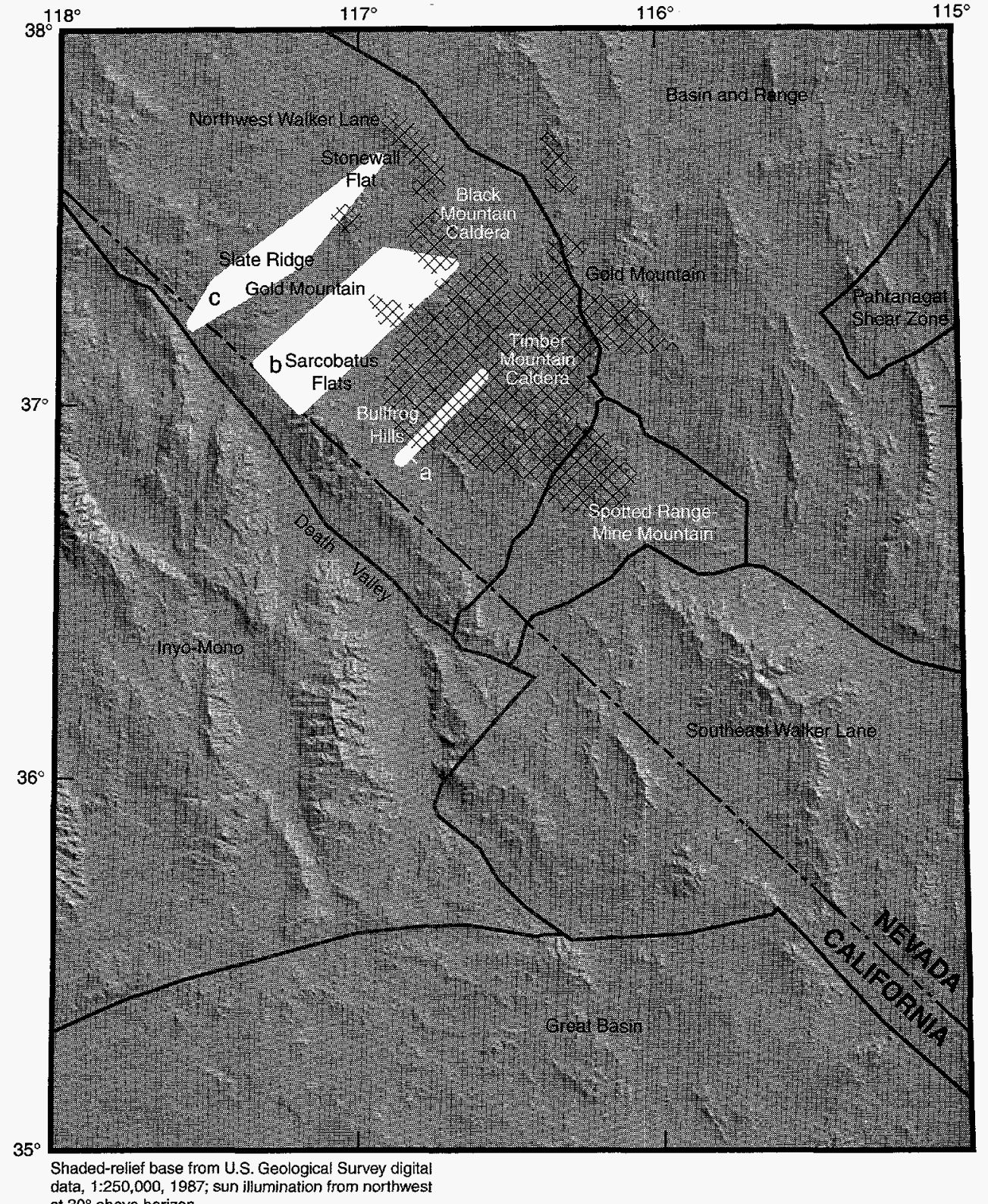
data, $1: 250,000,1987$; sun illumination from northwest at $30^{\circ}$ above horizon
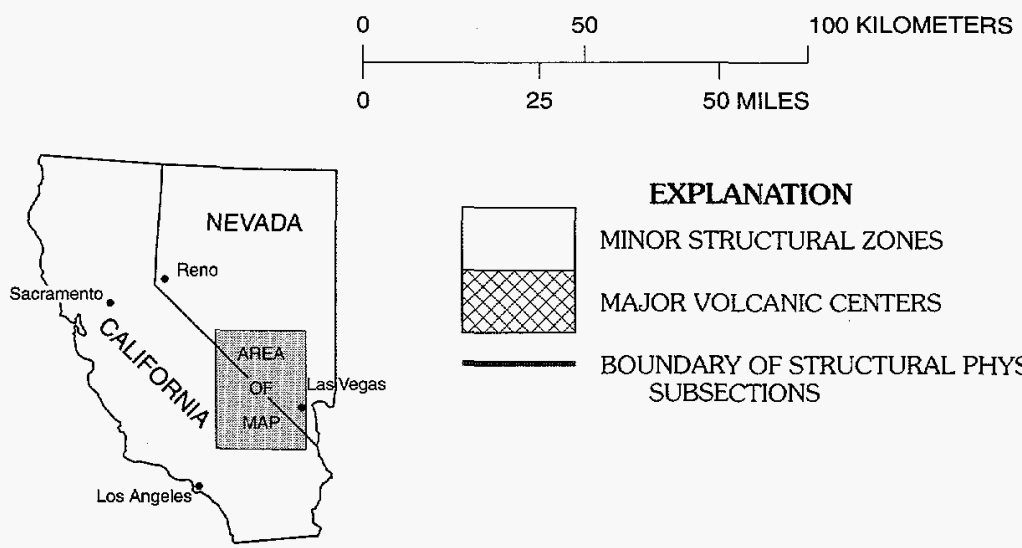

MAJOR VOLCANIC CENTERS

BOUNDARY OF STRUCTURAL PHYSIOGRAPHIC SUBSECTIONS

Figure 3. Structural-physiographic subsections (modified from Carr, 1990). Major volcanic centers are shaded (W.J. Carr, written commun., 1990). 
the deposition of silicic volcanic rocks. The second phase of extensional tectonics was characterized by reduced volcanic activity and was important in shaping present-day topography. Low-angle gravity faulting, such as the detachment fault present at Bare Mountain and Death Valley, is recognized as a way to accommodate extension of the upper crustal rocks (Hamilton, 1988; Carr, 1990). Late Cenozoic tilting and warping also are evident (Grose and Smith, 1989). Tectonic activity in the Basin and Range province has continued to historic times, as indicated by historic faulting in the study area. Carr (1982) suggests that basin and range deformation has decreased in the last few million years because the amount of offset along normal faults decreases nearer to the surface.

The basin and range tectonics are superimposed on the Walker Lane Belt, a northwest-trending, rightlateral, strike-slip shear zone located near the southern Nevada-California border (Lock and others, 1940; Longwell, 1960; Stewart, 1971, 1978). The Walker Lane Belt is part of a megastructure that crosses the Basin and Range Province from Texas to Oregon (Carr, 1990). The Walker Lane Belt separates the northwest structural-physiographic trends in the southwestern Great Basin, east of the Sierra Nevada, from the predominantly north-south trend of the more typical basin and range structure. The belt has long been recognized as an area of active faulting containing patterns of faults that are anomalous with respect to the typical fault patterns in the Great Basin (Reheis, 1990). The belt is dominated by lateral rather than dip-slip faulting, and except for caldera structures, large vertical displacements are not characteristic (Carr, 1990).

The Las Vegas Valley shear zone and the Furnace Creek-Death Valley fault system are major structural features associated with the Walker Lane shear zone. The Las Vegas Valley shear zone is a rightlateral shear zone with lateral displacements ranging from 44 to $69 \mathrm{~km}$. The Furnace Creek-Death Valley fault system is an en-echelon, right-lateral, strike-slip fault system with estimated offsets of 10 to $80 \mathrm{~km}$ (Reynolds, 1974). These structures are shown in figure 2. The shear zones of the Walker Lane Belt are transform-like in the sense that they may display greater extension on one side than the other, and they have finite length, typically ending abruptly at northto northeast-striking structural zones that appear to absorb the right-lateral component by extension on normal or oblique-slip faults (Anderson, 1973).
Within the study area, the southern Great Basin has diverse structural trends, styles, and tectonic activity (Carr, 1988). Carr (1990) divided the area into four major structural-physiographic subsections: Basin and Range, Walker Lane, Inyo-Mono, and undifferentiated southern Great Basin. Within these subsections are two northeast-trending structural zones: the Spotted Range-Mine Mountain zone and the Pahranagat shear zone (fig. 3). Each of these subsections may have different structural properties and mechanics. As a result, the tectonic conditions of each area must be analyzed separately in order to determine structural properties and mechanics, such as relative tension, compression, or shear. As shown in figure 3 , a series of major volcanic centers is superimposed on these subsections (Carr, 1990). This volcanic activity both affects and results from the tectonic stress and the structural mechanics of the region.

\section{Definition and Distribution of Hydrogeologic Units}

In a basin setting, under idealized conditions, ground water generally moves downward in recharge areas, then laterally toward discharge areas, and finally upward in discharge areas (fig. 4). However, conditions for idealized flow are rarely satisfied under natural conditions, particularly in geologically, climatically, and ecologically complex regions.

The conceptual model used is derived from those proposed by Bedinger and others (1989a, 1989c), Winograd and Thordarson (1975), and Waddell (1982). Conceptually, the ground-water flow system can be thought of as a series of connected intermontane basins, shown in figure 4 , in which there is localized ground-water flow in basin-fill deposits, clastic rocks, carbonate rocks, and volcanic rocks (P.O. Sinton, U.S. Geological Survey, written commun., 1987). Superimposed on the flow system are local and regional structures. These structures, faults and associated fractures connect the intermontane basins. As a result, the regional flow system is largely fault and fracture controlled. The dominant flow direction is to the south and southwest through interbasinal flow (P.O. Sinton, U.S. Geological Survey, written commun., 1987; Downey and others, 1990; Hunt and Robison, 1960; Hunt and others, 1966). 


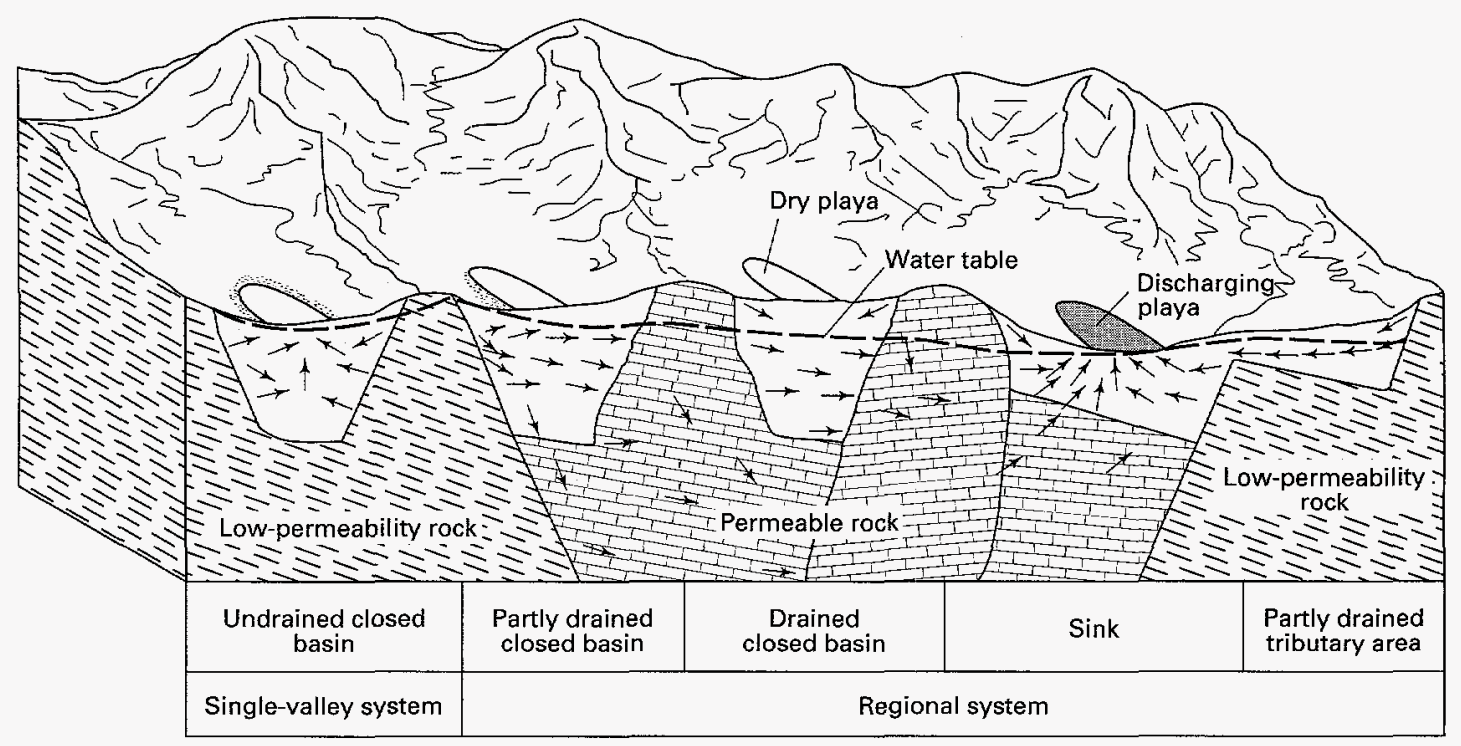

AREAS OF GROUND-WATER EVAPOTRANSPIRATION

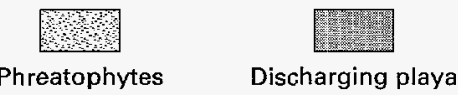

Figure 4. Observed configurations of ground-water flow in the Great Basin (from Eakin and others, 1976).

The surface expression of the hydrogeologic framework is characterized by the mountain ranges, volcanic tablelands, and alluvial valleys that dominate the geomorphic character of the region. The mountain ranges consist primarily of uplifted, faulted, and exhumed rocks of metamorphic and sedimentary origin. Locally, these rocks have been intruded or overlain by both volcanic and intrusive rocks of many different ages and compositions. The way in which these rocks were deposited, lithified, deformed, fractured, and weathered ultimately controls the way in which ground water enters, flows through, and exits the hydrogeologic system. Since these characteristics vary from the surface to the subsurface, describing these varying properties is critical to understanding the regional ground-water flow system (Hollett and others, 1991).

The framework forming a hydrogeologic system includes hydrogeologic units. A hydrogeologic unit is a unit that has considerable lateral extent and has reasonably distinct hydrologic properties because of its physical (geologic and structural) characteristics (Maxey, 1968). Winograd and Thordarson (1975) divided and categorized the geologic units occurring at the Nevada Test Site on the basis of their hydrologic properties. Waddell (1982) further described these hydrogeologic units while constructing a numerical ground-water flow model. These authors used hydrogeologic units to describe the aquifers and confining units. Bedinger and others $(1989 \mathrm{a}, 1989 \mathrm{c})$ expanded Winograd and Thordarson's hydrogeologic units while describing the hydrogeology of the Death Valley region. Grose (1983) and Grose and Smith (1989) subsequently developed cross sections for the Death Valley region based on the hydrogeologic units defined by Bedinger and others (1989a, 1989c). Ten hydrogeologic units for the Death Valley region are summarized in table 1 (Faunt and others, 1995). Although all the major geological features are retained, many of the smaller geologic units are grouped into larger entities by generalizing both lithologic and hydrologic properties of the bedrock geology units.

\section{Playa Deposits of Quaternary Age}

The lacustrine confining beds, lakebed sediments of Quaternary age, are a relatively homogeneous deposit composed of mainly clay-sized 
Table 1. Estimated hydraulic conductivity of hydrogeologic units in the Death Valley region

\begin{tabular}{|c|c|c|}
\hline $\begin{array}{l}\text { Hydrogeologic } \\
\text { unit }\end{array}$ & Description & $\begin{array}{l}\text { Approximate hydraulic conductivity } \\
\text { (meters/day) }\end{array}$ \\
\hline $\begin{array}{l}\text { Playa deposits of Quaternary } \\
\text { age }\end{array}$ & Lakebed deposits of silt and clay & $2 \times 10^{-04}($ all depths fractured or unfractured $)$ \\
\hline $\begin{array}{l}\text { Valley fill of Quaternary- } \\
\text { Tertiary age }\end{array}$ & $\begin{array}{l}\text { Alluvial (stream channel and fan gravels), } \\
\text { colluvial, ash fall, and lake deposits }\end{array}$ & $1 \times 10^{-01}$ (all depths fractured or unfractured) \\
\hline $\begin{array}{l}\text { Lava flows of Quaternary- } \\
\text { Tertiary age }\end{array}$ & Rhyolitic, andesitic, and basaltic lava flows & $\begin{array}{l}4 \times 10^{-04}(\text { unfractured }>150 \mathrm{~m} \text { deep }) \\
\left.5 \times 10^{-01} \text { (unfractured }<150 \mathrm{~m} \text { deep; fractured }\right)\end{array}$ \\
\hline $\begin{array}{l}\text { Volcanic rocks of Tertiary } \\
\text { age }\end{array}$ & Dominantly rhyolitic ash flow tuffs & $\begin{array}{l}1 \times 10^{+00} \text { (unfractured }<150 \mathrm{~m} \text { deep; fractured }<3 \mathrm{~km} \text { deep) } \\
4 \times 10^{+04} \text { (unfractured }>150 \mathrm{~m} \text { deep; fractured }>3 \mathrm{~km} \text { deep) }\end{array}$ \\
\hline $\begin{array}{l}\text { Volcanic rocks and } \\
\text { volcaniclastic rocks } \\
\text { of Tertiary age }\end{array}$ & Tuffs and tuffaceous clastic rocks & $4 \times 10^{-05}$ (all depths fractured or unfractured) \\
\hline $\begin{array}{l}\text { Granitic rocks of Tertiary- } \\
\text { Late Jurassic age }\end{array}$ & Granitic rocks & $\begin{array}{l}3 \times 10^{-07}(\text { fractured }>300 \mathrm{~m} \text { deep }) \\
\left.3 \times 10^{-02} \text { (weathered }<300 \mathrm{~m} \text { deep }\right) \\
\left.5 \times 10^{-04} \text { (fractured }<300 \mathrm{~m} \text { deep }\right)\end{array}$ \\
\hline $\begin{array}{l}\text { Sedimentary and metavolcanic } \\
\text { rocks of Mesozoic age }\end{array}$ & Dominantly sandstones & $3 \times 10^{-02}$ (all depths fractured or unfractured) \\
\hline $\begin{array}{l}\text { Carbonate rocks of Paleozoic } \\
\text { age }\end{array}$ & Limestones, dolomites, and calcareous shales & $\begin{array}{l}3 \times 10^{-03} \text { (unfractured }>150 \mathrm{~m} \text { deep) } \\
6 \times 10^{-01} \text { (unfractured }<150 \mathrm{~m} \text { deep; fractured }<3 \mathrm{~km} \text { deep) }\end{array}$ \\
\hline $\begin{array}{l}\text { Clastic rocks of Precambrian- } \\
\text { Paleozoic age }\end{array}$ & Conglomerates, argillites, and quartzites & $\begin{array}{l}5 \times 10^{-07} \text { (unfractured) } \\
3 \times 10 \text { (fractured) }\end{array}$ \\
\hline $\begin{array}{l}\text { Metamorphic rocks of } \\
\text { Precambrian age }\end{array}$ & $\begin{array}{l}\text { Crystalline rocks (gneisses, schists, and } \\
\text { migmatites) }\end{array}$ & $\begin{array}{l}3 \times 10^{-02} \text { (weathered }<300 \mathrm{~m} \text { deep) } \\
3 \times 10^{-07} \text { (fractured }>300 \mathrm{~m} \text { deep) } \\
5 \times 10^{-04} \text { (fractured }<300 \mathrm{~m} \text { deep) }\end{array}$ \\
\hline
\end{tabular}

Sources: Waddell (1982) and Bedinger and others (1989a, 1989b).

particles. The unit includes fine-grained playa deposits, lacustrine limestone, and evaporites. Accordingly, the unit can exhibit matrix flow from the permeable unconsolidated deposits, and faultand fracture-controlled flow in consolidated deposits (Downey and others, 1990). The lacustrine beds were deposited contemporaneously with the younger alluvial sediments. As a result, the deposits grade into each other. In some of the valleys, the lacustrine confining beds are several hundred meters thick.

\section{Valley Fill of Quaternary-Tertiary Age}

The alluvial sediments of Quaternary-Tertiary age are a heterogeneous mixture of volcanic and sedimentary rock detritus ranging from clay to boulder size. The heterogeneous mixture includes units of fine-grained playa and lakebeds containing evaporites (of limited areal extent), boulder-cobble-pebble debris flow and fan deposits, and volcanic tuffs. Accordingly, they may exhibit matrix flow as a result of the permeable unconsolidated materials, but fault- and fracture-controlled flow in more indurated materials (Downey and others, 1990). The basin fill (including fluvial deposits) was accumulated largely in structural basins. As a result, the basin-fill deposits range in thickness from zero at margins of valleys to several hundred meters in valley lowlands. The fill in many basins is greater than $1,300 \mathrm{~m}$ thick and may be as thick as $2,000 \mathrm{~m}$ (Bedinger and others, 1989a). The basin fill forms the major aquifer system in many of the valleys. 
These basin-fill aquifers constitute a regional system because of the similarities between basins, and because they are the most developed source of ground water in the region. Some basins are topographically and hydraulically closed by impermeable bedrock, while others are part of multibasin flow systems connected by perennial streams or by flow through the basin fill or permeable bedrock (fig. 4). Well yields within the basin fill seem to be related to physiographic setting (Plume and Carlton, 1988). The hydrologic properties of these deposits can differ greatly over short distances, both laterally and vertically, because of abrupt changes in grain size and the degree of sorting and consolidation.

\section{Volcanic Rocks of Quaternary-Tertiary Age}

The volcanic rocks, including lava flows and undifferentiated volcanic rocks of Tertiary and Quaternary age, underlie the valleys and crop out extensively in many of the mountains. The lava flows are primarily basalts, andesites, and rhyolites of Tertiary and Quaternary age. Columnar jointing and platy fractures are common in the flows, which vary from vesicular to dense. Secondary openings are developed along fractures and bedding planes. Individual flows generally are less than $33 \mathrm{~m}$ thick; some are less than $1 \mathrm{~m}$ thick (Bedinger and others, 1989a). Aggregate thicknesses are as much as $1,000 \mathrm{~m}$ (Bedinger and others, 1989a).

\section{Volcanic Rocks of Tertiary Age}

These volcanic rocks include tuffs and undifferentiated volcanic rocks of Tertiary and Quaternary age. They underlie the valleys and crop out extensively in northern and central portions of the area, including the Yucca Mountain area, where tuffs of Tertiary age are widespread. These units have an aggregate thickness of more than $4,000 \mathrm{~m}$. The composition and structure of these volcanic tablelands, and their position and mode of emplacement, drastically affect regional ground-water flow by altering flow paths, providing numerous avenues of recharge, and altering water-table gradients.

This hydrogeologic unit includes densely welded to nonwelded, bedded, reworked, and airfall tuffs. Welded ash-flow tuffs characteristically have an interstitial porosity of about 5 percent or less
(Bedinger and others, 1989a); thus, the commonly moderate to large hydraulic conductivity of welded ash-flow tuffs is largely a function of secondary openings along joints, bedding planes, and partings within the flows. Where these welded tuffs are not fractured or jointed, they tend to form confining beds; thus, welded tuffs can only transmit significant quantities of water where they are fractured.

In contrast, nonwelded ash-flow tuffs may have a large interstitial porosity, but low hydraulic: conductivity, and function as confining beds. Fractures and joints are virtually absent in nonwelded ash-flow tuffs (I.J. Winograd, U.S. Geological Survey, written commun., 1971). Hence, the nonwelded tuffs generally act as confining units. These nonwelded tuffs, however, have limited areal extent.

\section{Volcanic and Volcaniclastic Rocks of Tertiary Age}

The clastic and tuffaceous aquifers and confining beds are composed of tuffs and associated sedimentary rocks. They include up to $1,500 \mathrm{~m}$ of a variety of nonwelded to welded ash-flow tuff, ashfall tuff, tuff breccia, breccia flow deposits, tuffaceous sandstone, siltstone, mudstone, freshwater limestone, and minor amounts of densely welded tuff. Despite the widely differing origins of these rocks, this unit usually has matrices consisting of zeolite or clay minerals (Winograd and Thordarson, 1975), which results in low hydraulic conductivity. Some of the limestone and densely welded tuff may not have zeolitic or clayey matrices, but are believed to have low hydraulic conductivity (Winograd and Thordarson, 1975). These rocks usually separate the more permeable volcanic rocks from the Paleozoic carbonate rocks.

\section{Granitic Rocks of Tertiary-Late Jurassic Age}

Granitic rocks of Mesozoic and Tertiary age are widespread throughout the southern portion of the region. They outcrop in many mountain ranges and underlie most of the southern portion of the region at depth (Bedinger and others, 1989a). Ground water is thought to occur in these crystalline rocks only where they are fractured. Because the fractures are poorly connected, these rocks are believed to act mostly as confining units. 


\section{Sedimentary and Metavolcanic Rocks of Mesozoic Age}

The clastic rocks of Mesozoic age are composed of predominantly continental fluvial, lacustrine, and eolian deposits and clastic and carbonate sedimentary rocks. These rocks form extensive outcrops on the sides of the Spring Mountains where they have been thrusted up. The rocks have a variable thickness due to the extensive thrust faulting and are some of the more permeable rocks in the Death Valley region; however, they are not widespread. Some thin sections of the rocks also are found in the southwestern portion of the Death Valley region (Bedinger and others, 1989a).

\section{Carbonate Rocks of Paleozoic Age}

Limestone, dolomite, and calcareous shales of Paleozoic age underlie many valleys and outcrop along the flanks of and throughout some mountains. These carbonate rocks cover an extensive portion of the area around Death Valley, extending to the north and east. They are often interbedded with siltstones and shales and locally interrupted by volcanic rocks in the north. These carbonate rocks, which have an aggregate thickness of about $8,000 \mathrm{~m}$, are probably the most permeable rocks in the area. Where hydraulically connected, they contribute significantly to interbasinal movement of water. This interbasinal movement includes: (1) movement of water within the groundwater basin between topographic basins (fig. 4), and (2) the entrance of ground water from basins to the northeast.

Many of the springs in the area are associated with the carbonate rocks. Intergranular flow is not significant in these rocks; the large transmissivity is primarily due to fractures and solution channels (Winograd and Thordarson, 1975). Hydraulic tests of carbonate-rock aquifers throughout eastern and southern Nevada indicate that faults can increase their transmissivity by factors of 25 times or more (Dettinger, 1989).

\section{Clastic Rocks of Paleozoic-Precambrian Age}

Siltstone, quartzite, shale, sandstone, and some metamorphic rocks of Paleozoic age form clastic confining units. These rocks vary in aggregate thickness with a maximum thickness of about $3,500 \mathrm{~m}$. These rocks have negligible interstitial ground-water movement, but frequently are highly fractured and locally brecciated (Winograd and Thordarson, 1975). At shallow depths, these fractures and breccias can be conduits to flow, converting these clastic rocks into locally important shallow aquifers.

Clastic rocks in the region differ hydrologically from carbonate rocks in two important ways. First, secondary porosity rarely develops along bedding planes in any of the clastic rocks because of the low solubility of their constituents including quartz, mica, and clay minerals. Second, the clastic rocks deform more plastically than the carbonates and, as a result, fractures may become sealed or isolated during deformation (Winograd and Thordarson, 1975). In these rocks, the fractures may be sealed by continued deformation caused by the same process that formed them or by later plastic deformation. Open fractures in interbedded competent rocks may be sealed by plastic deformation of the less competent interbedded strata (Winograd and Thordarson, 1975).

One of the important clastic rocks in the region is the Eleana Formation, which contains dominantly relatively impermeable argillites and shales. These rocks tend to deform plastically, probably by shearing and tight folding. As a result, open fractures are unlikely to occur in the formation at depth. The presence or absence of the Eleana Formation greatly affects the ground-water flow system. The Eleana Formation is of hydrologic importance beneath western Yucca Flat and northern Jackass Flats, where it is thousands of feet thick and stratigraphically and hydraulically separates the carbonate aquifer into the upper and the lower carbonate aquifers (Winograd and Thordarson, 1975). Steep hydraulic gradients in these areas are attributed to the low gross transmissibility of the Eleana Formation (Winograd and Thordarson, 1975). Hydraulic compartmentalization is thought to occur throughout the study area owing to the complex geologic structure.

\section{Igneous and Metamorphic Rocks of Precambrian Age}

Crystalline metamorphic and igneous rocks of Precambrian age are widespread throughout the southern part of the region, cropping out in many mountain ranges and underlying most of the area at depth (Bedinger and others, 1989a). Hydrologically, this unit behaves similarly to the other crystalline 
rocks in the region. Ground water is thought to occur only locally in these crystalline bodies where the rock is fractured. Because the fractures are poorly connected, these rocks are believed to act mostly as confining units.

\section{Recharge, Discharge, and Boundary Fluxes}

The Death Valley regional ground-water basin is not an isolated basin. Ground-water flow in the Death Valley region typically is not coincident with topographic basins. Ground-water flow in, into, and out of the basin is quite complex and reflects the presence of a large carbonate aquifer draining the basin and the effects of structural and lithologic controls in the compartmentalization of flow into local, subregional, and regional subsystems (Bedinger and others, 1989c). Regional interbasinal groundwater movement is affected by the deformed nature of the great thicknesses of Paleozoic carbonate and clastic rocks. Major wrench, thrust, and normal faults and folds have been shown to have a significant effect on this ground-water movement (Winograd and Thordarson, 1975). Most of the ground water flows into the boundaries of the basin by way of interbasinal flux (fig. 5).

In addition to interbasinal flux, increased precipitation in the topographically high regions within this study area is a major source of recharge into the regional ground-water flow system. Recharge of this kind dominantly occurs at the mountain ranges that rim the ground-water basin. Smaller amounts of recharge occur through recycled irrigation and domestic water, as well as seepage of spring discharge back into the ground-water system (Rice, 1984). Pahrump and Amargosa Valleys both exhibit this type of recharge. However, these lesser components are perhaps so volumetrically small compared to regional infiltration and interbasinal flux that they may be considered negligible.

Much of the deep infiltration, or recharge, is from winter and spring storms that produce heavy snows in the mountains. These mountains can sustain a significant snowpack that melts and infiltrates as recharge. During spring melt, the water seeps slowly into the fractures or into permeable bedrock or flows off to adjacent drainages where water seeps into alluvium as recharge (Burbey and Prudic, 1991).
Additional recharge may occur during infrequent but large storms that cause local runoff to stream channels where water infiltrates in concentrated areas along the channel. These recharge events are locally significant but are less so at regional scales. Snowmelt and stormrunoff water percolate through bedrock in outcrops of extensively fractured carbonate, clastic, and volcanic rocks. In areas where well-developed, thick, clay-rich soils have formed on tuff and argillaceous rocks, less infiltration occurs.

Natural ground-water discharge is by springs, evaporation in areas where the water level is near land surface, and transpiration by plants. Artificial discharge occurs in the form of ground-water pumping for agricultural, commercial, and residential uses (Bedinger and others, 1989c). The Death Valley salt pan has long been interpreted as the ultimate discharge area for the Death Valley regional ground-water flow system. Two other major discharge areas are the springs at Ash Meadows and Oasis Valley (fig. 1) (Winograd and Thordarson, 1975).

\section{ASSESSMENT OF CRUSTAL STRESS AND FAULT-TRACE ORIENTATIONS}

The hydrogeologic conceptual model of the Death Valley regional ground-water flow system, as developed in the background section, identified the importance of regional structures in defining the character of the system. Large interbasinal groundwater flow systems occur in the region. Such water movements must be a result of regional structures.

Since the purpose of this study is to characterize the effects of faults on ground-water flow, information regarding their ability to control ground water must be examined. Knowledge of the current crustal stress field is important to any evaluation of the hydraulic controls exerted by geologic structures.

In this report, crustal stress concepts and measurement techniques are reviewed and all available crustal stress measurements are compiled for the Death Valley region. Statistical summaries of these data were made to determine the relative accuracy of the measurement and to identify the orientation of the present-day crustal stress field within the region. Structural-physiographic subsections previously identified by Carr (1990) were used to provide a convenient means of describing and categorizing the areal variations in tectonic regimes. 


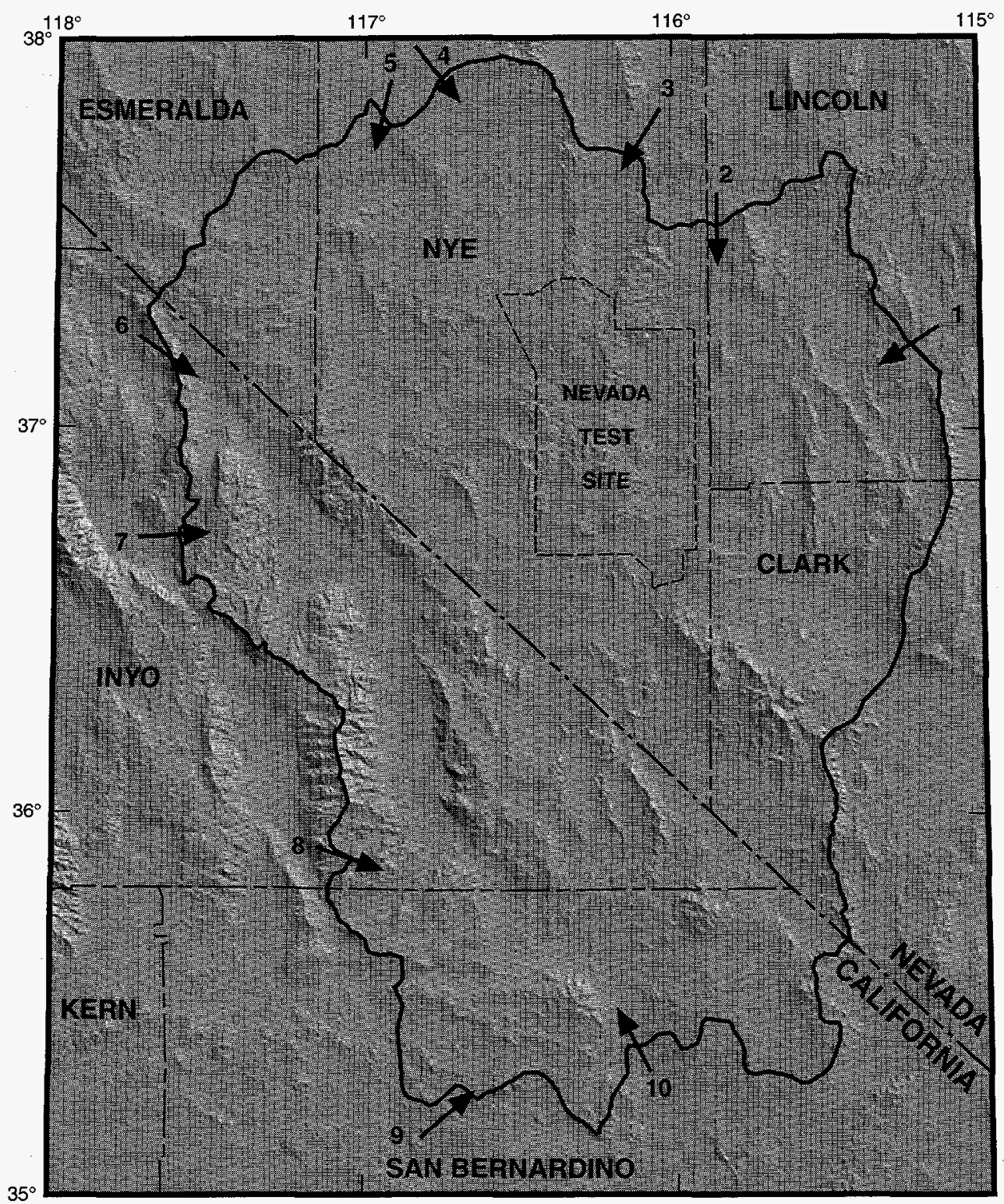

Shaded-relief base from U.S. Geological Survey digital data, $1: 250,000,1987$; sun illumination from northwest at $30^{\circ}$ above horizon
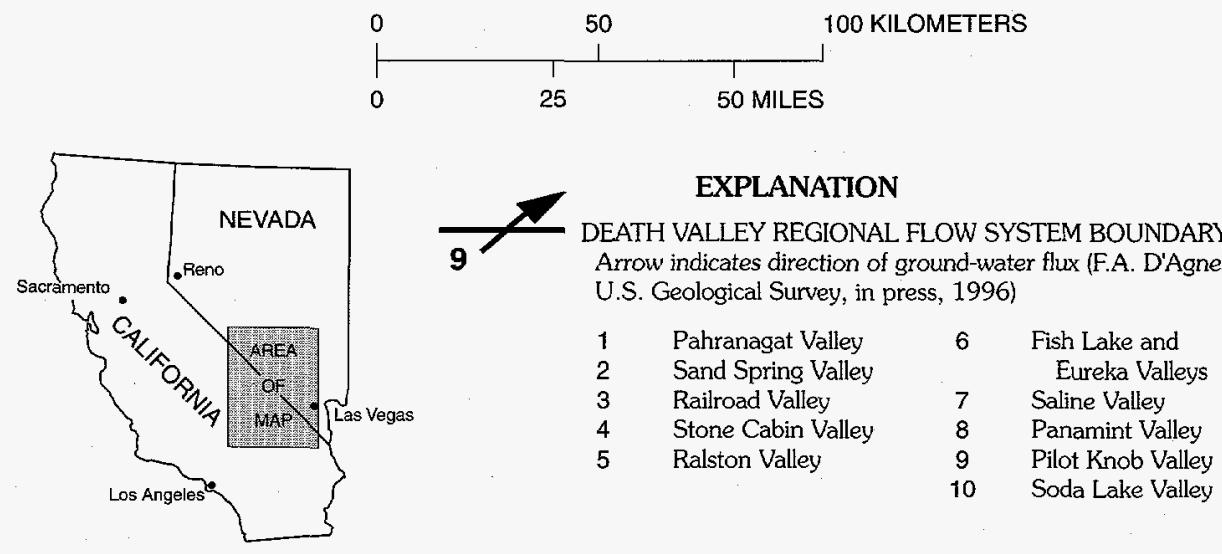

Figure 5. Directions of ground-water flux into the Death Valley ground-water basin (D'Agnese and others, in press). 
Fault distributions and orientations were developed for the Death Valley region by combining fault traces shown on numerous geologic maps at various scales with an interpretation of "anomalous drainages" interpreted from an analysis of USGS Digital Line Graphs (DLG's) hydrographic data maps (U.S. Geological Survey, 1989). Anomalous drainage patterns may represent previously unmapped regional fault or fracture zones in a region whose long and complex tectonic history has led to pervasive weakening and deformation. Statistical summaries of these fault orientations were made.

\section{Crustal Stress Theory}

Crustal stress results from gravitational loading and tectonic processes (Bucknam, 1973). The magnitude and direction of regional principal stress axes are closely associated with plate tectonics, igneous intrusions, faulting, and earthquake triggering. The upper part of the Earth's crust is composed of several large, nearly rigid plates that can move relative to one another. Both the driving mechanism and the interactions at plate edges can generate stresses that translate vast distances (Bucknam, 1973). Stresses in the Death Valley region appear to be related primarily to the relative motions of the Pacific and North American plates (Smith and Sbar, 1974).

In the southern Basin and Range Province, evidence indicates that one principal stress axis is vertical, and the horizontal components of the stress field represent the other two principal stress axes (Zoback and Zoback, 1980b). In a three-dimensional system, the vertical stress component is always principal (except at the surface), but in subvertical structural systems, the vertical stress component is irrelevant.

Carr (1974) proposed that most of the NTS is undergoing extension in a N. $50^{\circ} \mathrm{W}$. to $\mathrm{S} .50^{\circ} \mathrm{E}$. direction that coincides with the minimum principal stress direction. Carr supported his tectonic concepts with several lines of evidence including: (1) tectonic similarities between NTS faulting and the NevadaCalifornia seismic belt, (2) historic natural and explosion fractures, (3) absence of northwest-trending faults, (4) characteristics of faults and basin configurations, (5) seismic evidence, (6) strain measurements,
(7) stress estimates, and (8) orientation of the enlargement of drill holes (Carr, 1974). In 1990, Carr suggested that the study area may be divided into six structural-physiographic subsections: Basin and Range, Walker Lane, Inyo-Mono, undifferentiated southern Great Basin, Spotted Range-Mine Mountain zone, and the Pahranagat shear zone (fig. 3). Two major volcanic centers both reflect and affect the regional tectonic stresses. The subsections proposed by Carr were used during this study to provide a convenient means for describing the areal variation in tectonic regimes.

\section{Crustal Stress Data}

Numerous investigations have been conducted regarding structural mechanics in the region. Many were related to earthquakes; others described measurements of stress in boreholes on the NTS. The sources are identified in table 2 and are included in the cited references. Zoback and Zoback (1980b) compiled principal stress-axis orientation data for the entire United States from numerous sources and, therefore, became a major source of information used in this study. Table 2 is a compilation of all the available crustal stress data for the Death Valley region defining the orientation of the minimum principal stress axis. Most of these data lack any plunge values; therefore, all these data were treated as the horizontal component of the principal stress in this study. Measurements at three nearby locations are included to help define the orientation of the principal stress axes in the southern part of the study area. The geographic distribution of the data in table 2 is shown in figure 6.

\section{Methods of Crustal Stress Measurement}

Common methods of estimating stress components resulting from tectonic processes are based on: (1) seismic first-motion data, (2) characteristics of body waves and surface waves from explosions and earthquakes, (3) pattern of natural and explosionproduced strain fields, and (4) analysis of fault patterns (Bucknam, 1973). These methods can be categorized into three main types of stress indicators: earthquake focal mechanism data, direct (in-place) stress measurements, and geologic data. 
Table 2. Compilation of the azimuth of the minimum horizontal principal stress axis in and around the Death Valley region

\begin{tabular}{|c|c|c|c|c|}
\hline Longitude & Latitude & Azimuth & Reference(s) & Method \\
\hline $117^{\circ} 48^{\prime} 00^{\prime \prime}$ & $35^{\circ} 55^{\prime} 12^{\prime \prime}$ & 294 & $\begin{array}{l}\text { Zoback and Zoback (1980b) } \\
\text { Smith and Lindh (1978) }\end{array}$ & Focal mechanism \\
\hline $117^{\circ} 49^{\prime} 48^{\prime \prime}$ & $36^{\circ} 00^{\prime} 00^{\prime \prime}$ & 280 & $\begin{array}{l}\text { Zoback and Zoback (1980b) } \\
\text { Weaver and Hill (1979) }\end{array}$ & $\begin{array}{l}\text { Focal mechanism, cinder } \\
\text { Cone alignment, dike trends }\end{array}$ \\
\hline $116^{\circ} 48^{\prime} 00^{\prime \prime}$ & $36^{\circ} 06^{\prime} 00^{\prime \prime}$ & 315 & $\begin{array}{l}\text { Zoback and Zoback (1980b) } \\
\text { Wright (1976) }\end{array}$ & Fault slip and grooves \\
\hline $116^{\circ} 16^{\prime} 12^{\prime \prime}$ & $36^{\circ} 36^{\prime} 00^{\prime \prime}$ & 354 & $\begin{array}{l}\text { Zoback and Zoback (1980b) } \\
\text { Smith and Lindh (1978) }\end{array}$ & Focal mechanism \\
\hline $116^{\circ} 00^{\prime} 00^{\prime \prime}$ & $37^{\circ} 00^{\prime} 00^{\prime \prime}$ & 310 & $\begin{array}{l}\text { Zoback and Zoback (1980b) } \\
\text { Carr (1974) }\end{array}$ & $\begin{array}{l}\text { Geologic, hydraulic } \\
\text { Fracturing, USBM } \\
\text { Overcoring, focal mechanism }\end{array}$ \\
\hline $116^{\circ} 30^{\prime} 00^{\prime \prime}$ & $37^{\circ} 12^{\prime} 00^{\prime \prime}$ & 315 & Zoback and Zoback (1980b) & Focal mechanism \\
\hline $117^{\circ} 19^{\prime} 12^{\prime \prime}$ & $37^{\circ} 07^{\prime} 48^{\prime \prime}$ & 310 & $\begin{array}{l}\text { Zoback and Zoback (1980b) } \\
\text { Smith and Lindh (1978) }\end{array}$ & Focal mechanism \\
\hline $117^{\circ} 52^{\prime} 12^{\prime \prime}$ & $37^{\circ} 28^{\prime} 12^{\prime \prime}$ & 272 & $\begin{array}{l}\text { Zoback and Zoback (1980b) } \\
\text { Smith and Lindh (1978) }\end{array}$ & Focal mechanism \\
\hline $115^{\circ} 03^{\prime} 00^{\prime \prime}$ & $37^{\circ} 43^{\prime} 48^{\prime \prime}$ & 309 & $\begin{array}{l}\text { Zoback and Zoback (1980b) } \\
\text { Smith and Lindh (1978) }\end{array}$ & Focal mechanism \\
\hline $116^{\circ} 00^{\prime} 00^{\prime \prime}$ & $37^{\circ} 45^{\prime} 00^{\prime \prime}$ & 354 & $\begin{array}{l}\text { Zoback and Zoback (1980b) } \\
\text { Smith and Lindh (1978) }\end{array}$ & Focal mechanism \\
\hline $116^{\circ} 28^{\prime} 01^{\prime \prime}$ & $36^{\circ} 49^{\prime} 05^{\prime \prime}$ & 309 & Warren and Smith (1985) & Hydraulic fracturing \\
\hline $116^{\circ} 28^{\prime} 01^{\prime \prime}$ & $36^{\circ} 49^{\prime} 05^{\prime \prime}$ & 308 & Warren and Smith (1985) & Hydraulic fracturing \\
\hline $116^{\circ} 28^{\prime} 01^{\prime \prime}$ & $36^{\circ} 49^{\prime} 05^{\prime \prime}$ & 252 & Warren and Smith (1985) & Hydraulic fracturing \\
\hline $116^{\circ} 28^{\prime} 00^{\prime \prime}$ & $36^{\circ} 53^{\prime} 00^{\prime \prime}$ & 295 & Stock and others (1986) & Hydraulic fracturing \\
\hline $116^{\circ} 30^{\prime} 00^{\prime \prime}$ & $38^{\circ} 00^{\prime} 00^{\prime \prime}$ & $220^{*}$ & Anderson and Ekren (1977) & Fault trends \\
\hline $116^{\circ} 52^{\prime} 30^{\prime \prime}$ & $37^{\circ} 45^{\prime} 00^{\prime \prime}$ & $230^{*}$ & Anderson and Ekren (1977) & Fault trends \\
\hline $116^{\circ} 45^{\prime} 00^{\prime \prime}$ & $37^{\circ} 37^{\prime} 30^{\prime \prime}$ & $265^{*}$ & Anderson and Ekren (1977) & Fault trends \\
\hline $116^{\circ} 35^{\prime} 00^{\prime \prime}$ & $37^{\circ} 37^{\prime} 30^{\prime \prime}$ & $245^{*}$ & Anderson and Ekren (1977) & Fault trends \\
\hline $116^{\circ} 20^{\prime} 00^{\prime \prime}$ & $37^{\circ} 41^{\prime} 00^{\prime \prime}$ & $248^{*}$ & Anderson and Ekren (1977) & Fault trends \\
\hline $115^{\circ} 55^{\prime} 00^{\prime \prime}$ & $37^{\circ} 05^{\prime} 00^{\prime \prime}$ & $250^{*}$ & Anderson and Ekren (1977) & Fault trends \\
\hline $115^{\circ} 00^{\prime} 00^{\prime \prime}$ & $37^{\circ} 00^{\prime} 00^{\prime \prime}$ & $250^{*}$ & Anderson and Ekren (1977) & Fault trends \\
\hline $116^{\circ} 04^{\prime} 30^{\prime \prime}$ & $36^{\circ} 43^{\prime} 30^{\prime \prime}$ & 298 & Frizzel and Zoback (1987) & Fault trends and slip \\
\hline $116^{\circ} 10^{\prime} 00^{\prime \prime}$ & $36^{\circ} 15^{\prime} 00^{\prime \prime}$ & 270 & Reheis and Noller (1990) & Trends - active faults \\
\hline $117^{\circ} 56^{\prime} 00^{\prime \prime}$ & $37^{\circ} 35^{\prime} 00^{\prime \prime}$ & 270 & Reheis and Noller (1990) & Trends - active faults \\
\hline $117^{\circ} 55^{\prime} 00^{\prime \prime}$ & $37^{\circ} 53^{\prime} 00^{\prime \prime}$ & 270 & Reheis and Noller (1990) & Trends - active faults \\
\hline $117^{\circ} 30^{\prime} 00^{\prime \prime}$ & $37^{\circ} 45^{\prime} 00^{\prime \prime}$ & 310 & Reheis and Noller (1990) & Trends - active faults \\
\hline $117^{\circ} 45^{\prime} 00^{\prime \prime}$ & $37^{\circ} 20^{\prime} 00^{\prime \prime}$ & 270 & Reheis and Noller (1990) & Trends - active faults \\
\hline $117^{\circ} 30^{\prime} 00^{\prime \prime}$ & $37^{\circ} 25^{\prime} 00^{\prime \prime}$ & 310 & Reheis and Noller (1990) & Trends - active faults \\
\hline $116^{\circ} 52^{\prime} 30^{\prime \prime}$ & $36^{\circ} 35^{\prime} 00^{\prime \prime}$ & 270 & Reheis and Noller (1990) & Trends - active faults \\
\hline $116^{\circ} 30^{\prime} 00^{\prime \prime}$ & $36^{\circ} 52^{\prime} 30^{\prime \prime}$ & 310 & Reheis and Noller (1990) & Trends - active faults \\
\hline $116^{\circ} 07^{\prime} 30^{\prime \prime}$ & $36^{\circ} 43^{\prime} 00^{\prime \prime}$ & 310 & Reheis and Noller (1990) & Trends - active faults \\
\hline $117^{\circ} 23^{\prime} 13^{\prime \prime}$ & $37^{\circ} 08^{\prime} 53^{\prime \prime}$ & 301 & Rogers and others (1983) & Focal mechanism \\
\hline $116^{\circ} 55^{\prime} 01^{\prime \prime}$ & $37^{\circ} 09^{\prime} 18^{\prime \prime}$ & 314 & Rogers and others (1983) & Focal mechanism \\
\hline $116^{\circ} 57^{\prime} 18^{\prime \prime}$ & $37^{\circ} 03^{\prime} 18^{\prime \prime}$ & 323 & Rogers and others (1983) & Focal mechanism \\
\hline $116^{\circ} 34^{\prime} 12^{\prime \prime}$ & $37^{\circ} 11^{\prime} 06^{\prime \prime}$ & 311 & Rogers and others (1983) & Focal mechanism \\
\hline $115^{\circ} 42^{\prime} 29^{\prime \prime}$ & $36^{\circ} 43^{\prime} 30^{\prime \prime}$ & 297 & Rogers and others (1983) & Focal mechanism \\
\hline $115^{\circ} 57^{\prime} 40^{\prime \prime}$ & $36^{\circ} 51^{\prime} 36^{\prime \prime}$ & 296 & Rogers and others (1983) & Focal mechanism \\
\hline $116^{\circ} 09^{\prime} 43^{\prime \prime}$ & $36^{\circ} 52^{\prime} 26^{\prime \prime}$ & 318 & Rogers and others (1983) & Focal mechanism \\
\hline
\end{tabular}


Table 2. Compilation of the azimuth of the minimum horizontal principal stress axis in and around the Death Valley region-Continued

\begin{tabular}{|c|c|c|c|c|}
\hline Longitude & Latitude & Azimuth & Reference(s) & Method \\
\hline $116^{\circ} 16^{\prime} 01^{\prime \prime}$ & $36^{\circ} 48^{\prime} 40^{\prime \prime}$ & 312 & Rogers and others (1983) & Focal mechanism \\
\hline $115^{\circ} 01^{\prime} 44^{\prime \prime}$ & $37^{\circ} 14^{\prime} 17^{\prime \prime}$ & 310 & Rogers and others (1983) & Focal mechanism \\
\hline \multirow[t]{2}{*}{$115^{\circ} 52^{\prime} 48^{\prime \prime}$} & $36^{\circ} 48^{\prime} 36^{\prime \prime}$ & 293 & Smith and Lindh (1978) & Focal mechanism \\
\hline & & & Carr (1974) & \\
\hline \multirow[t]{2}{*}{$115^{\circ} 58^{\prime} 48^{\prime \prime}$} & $36^{\circ} 55^{\prime} 12^{\prime \prime}$ & 315 & Smith and Lindh (1978) & Focal mechanism \\
\hline & & & Carr (1974) & \\
\hline $116^{\circ} 00^{\prime} 00^{\prime \prime}$ & $36^{\circ} 51^{\prime} 00^{\prime \prime}$ & 305 & Carr (1974) & Fault slip and grooves \\
\hline $116^{\circ} 00^{\prime} 00^{\prime \prime}$ & $36^{\circ} 51^{\prime} 00^{\prime \prime}$ & 320 & Haimson and others (1974) & Hydraulic fracturing \\
\hline $116^{\circ} 15^{\prime} 14^{\prime \prime}$ & $36^{\circ} 46^{\prime} 37^{\prime \prime}$ & 281 & Rogers and others (1987) & Focal mechanism \\
\hline $116^{\circ} 04^{\prime} 41^{\prime \prime}$ & $36^{\circ} 39^{\prime} 43^{\prime \prime}$ & 296 & Rogers and others (1987) & Focal mechanism \\
\hline $116^{\circ} 35^{\prime} 10^{\prime \prime}$ & $36^{\circ} 30^{\prime} 07^{\prime \prime}$ & 309 & Rogers and others (1987) & Focal mechanism \\
\hline $116^{\circ} 34^{\prime} 08^{\prime \prime}$ & $36^{\circ} 30^{\prime} 07^{\prime \prime}$ & 311 & Rogers and others (1987) & Focal mechanism \\
\hline $116^{\circ} 34^{\prime} 05^{\prime \prime}$ & $36^{\circ} 30^{\prime} 00^{\prime \prime}$ & 266 & Rogers and others (1987) & Focal mechanism \\
\hline $116^{\circ} 24^{\prime} 07^{\prime \prime}$ & $36^{\circ} 39^{\prime} 11^{\prime \prime}$ & 299 & Rogers and others (1987) & Focal mechanism \\
\hline $116^{\circ} 16^{\prime} 12^{\prime \prime}$ & $36^{\circ} 41^{\prime} 17^{\prime \prime}$ & 294 & Rogers and others (1987) & Focal mechanism \\
\hline $116^{\circ} 24^{\prime} 50^{\prime \prime}$ & $36^{\circ} 59^{\prime} 46^{\prime \prime}$ & 322 & Rogers and others (1987) & Focal mechanism \\
\hline $116^{\circ} 35^{\prime} 31^{\prime \prime}$ & $37^{\circ} 10^{\prime} 52^{\prime \prime}$ & 286 & Rogers and others (1987) & Focal mechanism \\
\hline $116^{\circ} 35^{\prime} 24^{\prime \prime}$ & $37^{\circ} 11^{\prime} 02^{\prime \prime}$ & 290 & Rogers and others (1987) & Focal mechanism \\
\hline $116^{\circ} 56^{\prime} 49^{\prime \prime}$ & $37^{\circ} 04^{\prime} 26^{\prime \prime}$ & 313 & Rogers and others (1987) & Focal mechanism \\
\hline $116^{\circ} 56^{\prime} 53^{\prime \prime}$ & $37^{\circ} 03^{\prime} 58^{\prime \prime}$ & 335 & Rogers and others (1987) & Focal mechanism \\
\hline $116^{\circ} 56^{\prime} 49^{\prime \prime}$ & $37^{\circ} 04^{\prime} 26^{\prime \prime}$ & 346 & Rogers and others (1987) & Focal mechanism \\
\hline $116^{\circ} 56^{\prime} 24^{\prime \prime}$ & $37^{\circ} 09^{\prime} 04^{\prime \prime}$ & 312 & Rogers and others (1987) & Focal mechanism \\
\hline $117^{\circ} 05^{\prime} 53^{\prime \prime}$ & $37^{\circ} 25^{\prime} 34^{\prime \prime}$ & 285 & Rogers and others (1987) & Focal mechanism \\
\hline $117^{\circ} 05^{\prime} 49^{\prime \prime}$ & $37^{\circ} 25^{\prime} 30^{\prime \prime}$ & 323 & Rogers and others (1987) & Focal mechanism \\
\hline $117^{\circ} 16^{\prime} 48^{\prime \prime}$ & $37^{\circ} 21^{\prime} 11^{\prime \prime}$ & 285 & Rogers and others (1987) & Focal mechanism \\
\hline $115^{\circ} 44^{\prime} 20^{\prime \prime}$ & $36^{\circ} 42^{\prime} 54^{\prime \prime}$ & 331 & Rogers and others (1987) & Focal mechanism \\
\hline $115^{\circ} 02^{\prime} 13^{\prime \prime}$ & $37^{\circ} 41^{\prime} 53^{\prime \prime}$ & 311 & Rogers and others (1987) & Focal mechanism \\
\hline $116^{\circ} 28^{\prime} 01^{\prime \prime}$ & $36^{\circ} 49^{\prime} 05^{\prime \prime}$ & 295 & Stock and others (1986) & Hydraulic fracturing \\
\hline $116^{\circ} 25^{\prime} 21^{\prime \prime}$ & $36^{\circ} 49^{\prime} 38^{\prime \prime}$ & 300 & Stock and others (1986) & Borehole breakouts \\
\hline $116^{\circ} 13^{\prime} 00^{\prime \prime}$ & $37^{\circ} 13^{\prime} 00^{\prime \prime}$ & 306 & Ellis and Magner (1980) & USBM overcoring \\
\hline $116^{\circ} 12^{\prime} 00^{\prime \prime}$ & $37^{\circ} 11^{\prime} 42^{\prime \prime}$ & 305 & Haimson and others (1974) & Hydraulic fracturing \\
\hline $116^{\circ} 07^{\prime} 16^{\prime \prime}$ & $36^{\circ} 48^{\prime} 40^{\prime \prime}$ & 318 & Harmsen (1991) & Focal mechanism \\
\hline $116^{\circ} 22^{\prime} 44^{\prime \prime}$ & $37^{\circ} 11^{\prime} 35^{\prime \prime}$ & 337 & Harmsen (1991) & Focal mechanism \\
\hline $116^{\circ} 22^{\prime} 44^{\prime \prime}$ & $37^{\circ} 11^{\prime} 49^{\prime \prime}$ & 331 & Harmsen (1991) & Focal mechanism \\
\hline $117^{\circ} 03^{\prime} 43^{\prime \prime}$ & $37^{\circ} 07^{\prime} 26^{\prime \prime}$ & 310 & Harmsen (1991) & Focal mechanism \\
\hline $117^{\circ} 02^{\prime} 06^{\prime \prime}$ & $37^{\circ} 07^{\prime} 01^{\prime \prime}$ & 307 & Harmsen (1991) & Focal mechanism \\
\hline $116^{\circ} 52^{\prime} 34^{\prime \prime}$ & $37^{\circ} 05^{\prime} 46^{\prime \prime}$ & 326 & Harmsen (1991) & Focal mechanism \\
\hline $116^{\circ} 44^{\prime} 17^{\prime \prime}$ & $37^{\circ} 17^{\prime} 28^{\prime \prime}$ & 346 & Harmsen (1991) & Focal mechanism \\
\hline $116^{\circ} 19^{\prime} 05^{\prime \prime}$ & $36^{\circ} 51^{\prime} 47^{\prime \prime}$ & 328 & Harmsen (1991) & Focal mechanism \\
\hline $117^{\circ} 02^{\prime} 38^{\prime \prime}$ & $36^{\circ} 33^{\prime} 22^{\prime \prime}$ & 275 & Harmsen (1991) & Focal mechanism \\
\hline $116^{\circ} 58^{\prime} 55^{\prime \prime}$ & $37^{\circ} 08^{\prime} 49^{\prime \prime}$ & 310 & Harmsen (1991) & Focal mechanism \\
\hline $116^{\circ} 45^{\prime} 14^{\prime \prime}$ & $37^{\circ} 05^{\prime} 13^{\prime \prime}$ & 300 & Harmsen (1991) & Focal mechanism \\
\hline $117^{\circ} 13^{\prime} 44^{\prime \prime}$ & $37^{\circ} 26^{\prime} 20^{\prime \prime}$ & 288 & Harmsen (1991) & Focal mechanism \\
\hline $116^{\circ} 52^{\prime} 34^{\prime \prime}$ & $37^{\circ} 05^{\prime} 31^{\prime \prime}$ & 332 & Harmsen (1991) & Focal mechanism \\
\hline $116^{\circ} 52^{\prime} 37^{\prime \prime}$ & $37^{\circ} 05^{\prime} 38^{\prime \prime}$ & 316 & Harmsen (1991) & \\
\hline
\end{tabular}


Table 2. Compilation of the azimuth of the minimum horizontal principal stress axis in and around the Death Valley region-Continued

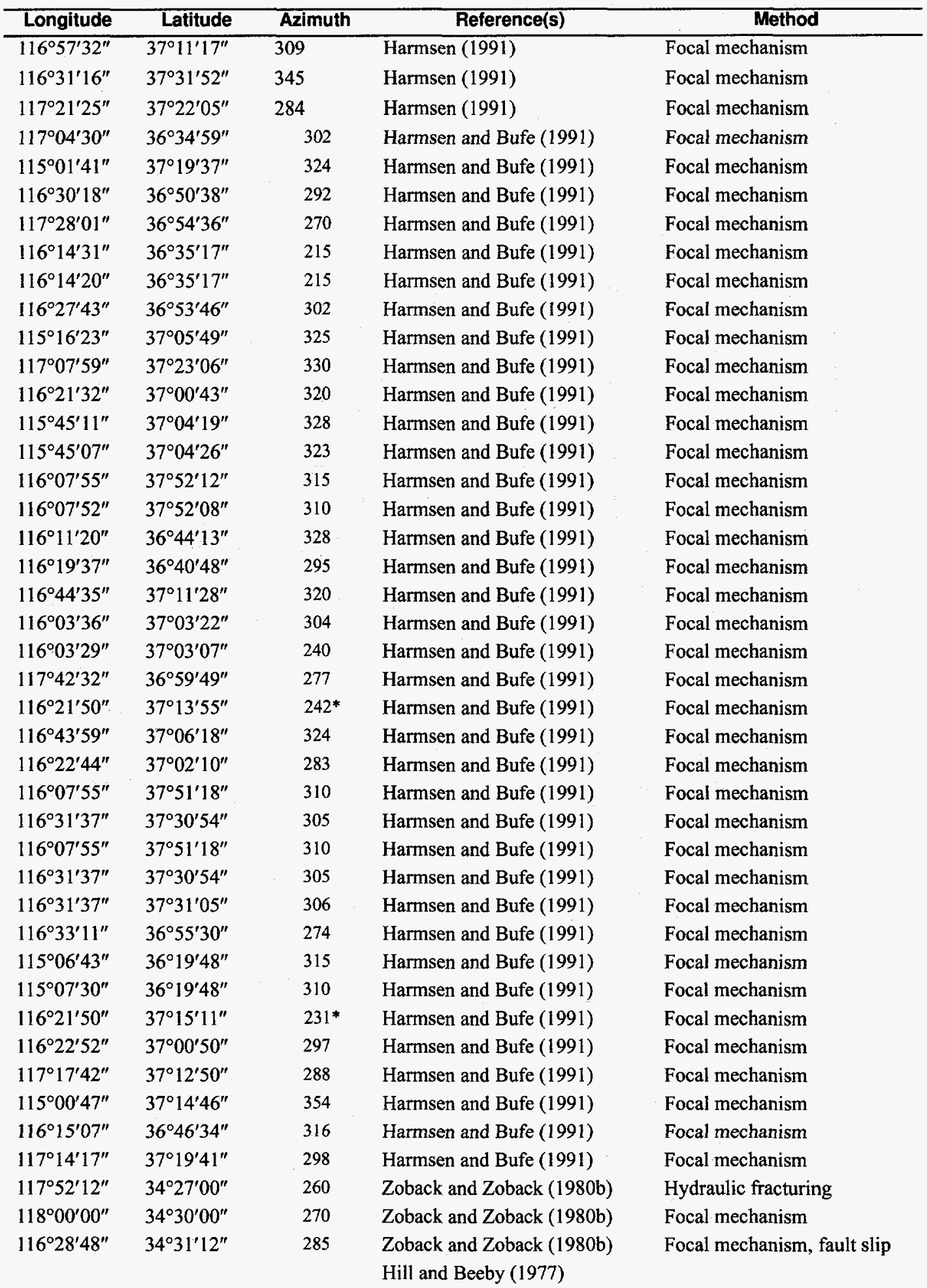

*Data not included in analyses

The minimum principal stress axis is a bidirectional measurement. The azimuth recorded in this table is for the western hemisphere. A value $180^{\circ}$ less than those recorded could just as easily have been tabulated. Plunge data are not included. 


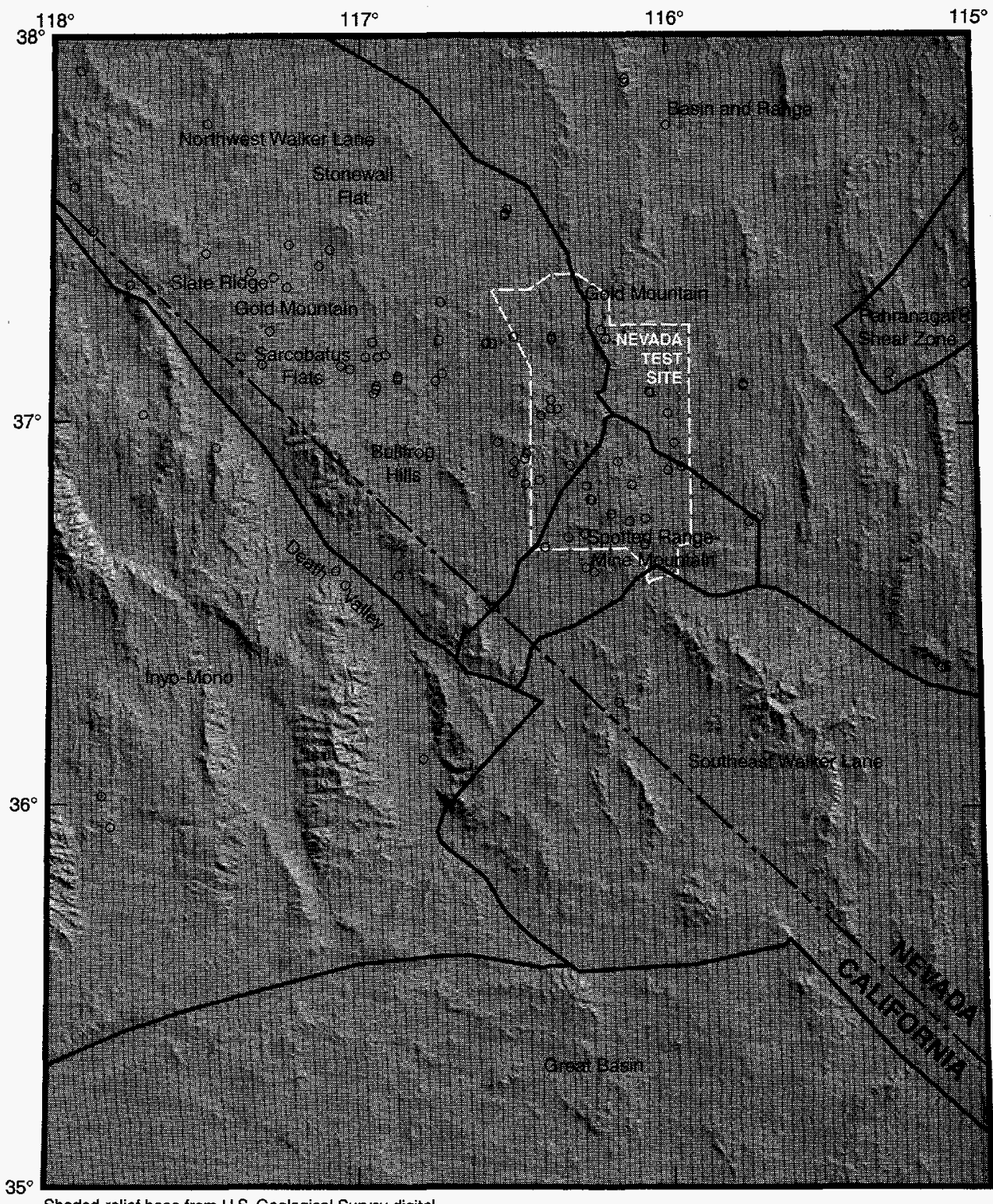

Shaded-relief base from U.S. Gealogical Survey digital data, 1:250,000, 1987; sun illumination from northwest

at $30^{\circ}$ above horizon
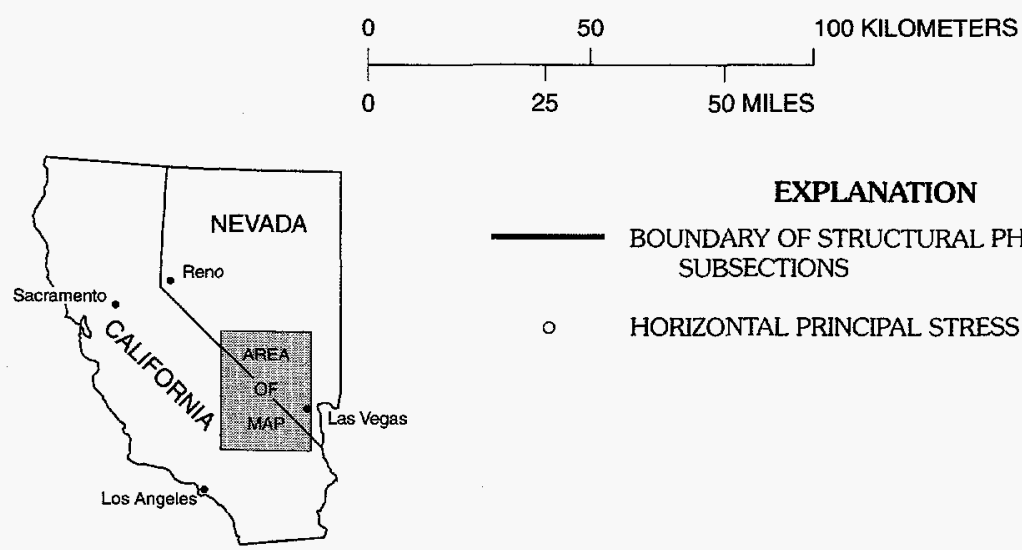

EXPLANATION

BOUNDARY OF STRUCTURAL PHYSIOGRAPHIC SUBSECTIONS

- HORIZONTAL. PRINCIPAL STRESS AXIS

Figure 6. Geographic distribution of minimum horizontal principal stress axis superimposed on the structural-physiographic subsections (shown in figure 3). 


\section{Earthquake Focal Mechanisms}

The seismic waves radiated from an earthquake may be used to estimate the magnitude and the orientation of the principal stresses (McKenzie, 1969). Focal mechanism studies provide interpretations of stress directions based on the inferred nature of movement at the earthquake focus, as judged from the pattern of first ground motion at seismic stations. Such determinations are among the most commonly used indicators of principal stress orientations. However, there are limitations to these estimates. Focal mechanism solutions consider earthquake faulting to result from failure of unfractured, homogeneous material without internal friction. Yet, many shallow earthquakes represent renewed slip along preexisting faults; they occur by failure on preexisting weak planes rather than by brittle fracture of a homogeneous material (McKenzie, 1969). The existence of such preexisting planes of weakness greatly limits the interpretation of principal stress orientations. The general correspondence of measured tension directions and principal stress axes determined from focal mechanisms suggests that these axes are reliable indicators of principal stress directions (Zoback and Zoback, 1980a).

\section{Direct (In-Place) Stress Measurements}

Principal stress orientations also may be obtained from in-place stress measurements (Zoback and Zoback, 1980a). In-place stress measurements are direct determinations of the orientation and magnitude of tectonic stress. They include hydraulic fracturing, borehole breakouts, and overcoring techniques. The hydraulic fracturing method consists of hydraulically isolating a section of a well or borehole and pressurizing the isolated section until a tensile fracture (a "hydrofracture") is induced at the well bore. Regardless of the obliquity of the borehole to the stress field, the hydraulic fracture should initiate at the azimuth of minimum compressive tangential stress in the borehole. Measured ellipticity of wells resulting from caving of walls ("breakouts") also has been proposed as a principal stress indicator (Zoback and Zoback, $1980 \mathrm{~b}$ ). Breakouts are spalled portions of the borehole wall that form by a combination of shear and tensile failure of the borehole wall. The U.S. Bureau of Mines has developed an overcoring method to determine the orientation of principal stresses at the NTS (Fitzpatrick, 1962). The method is based on the principle that when a sample is removed from its natural confinement, it will tend to deform and an originally circular borehole within the sample will become elliptical. By applying loads to such an "overcored" sample until the circularity of the borehole is restored, it is possible to determine the original stress orientations.

\section{Geologic Observations}

Geologic observations can be used to interpolate between points where stress orientations have been measured by in-place methods and may be used in the absence of direct instrumental stress measurements (Bucknam, 1973). Geologic information concerning principal stress orientations can be divided into two categories: observations of fault slip and orientations of lineaments of young volcanic feeders (Zoback and Zoback, 1980b).

In principle, the type of faulting combined with knowledge of the rock-strength properties may be used to determine an approximate orientation of the principal stresses that produced the faulting. However, the deformation of a material with preexisting planes of weakness may not follow traditional failure criteria. There is no reason to assume that rock structures formed millions of years in the past now reflect, or are related to, the present state of stress. Determinations of principal stress directions may be based on the type, sense of slip, offset, and orientation of faults and scarps. These may reflect the direction of extension or minimum principal stress (Reheis, 1990). Geologic indicators that demonstrate the sense of fault slip include: (1) historic offsets, (2) grooves and slickensides on exposed fault scarps, (3) core holes offset by motion on preexisting fault surfaces, and (4) trends and types of offset of young faults (Zoback and Zoback, 1980a). The occurrence of oblique slip suggests slip on favorably oriented preexisting planes of weakness. A simple geometric analysis of the data permits a qualitative estimate of the principal stress orientations (Frizzel and Zoback, 1987).

The second type of geologic indicator is the orientation of linear volcanic feeders, such as dikes and cinder cone alignments. In areas of active volcanism, lines of volcanic feeders can be used to determine principal stress orientations (Zoback and Zoback, 1980b). The volcanic activity aligns itself along the maximum principal stress axis with the minimum principal stress axis perpendicular to this lineation. 


\section{Statistical Summaries of Crustal Stress Data}

The data reported in table 2 were analyzed by the program ROSE (Rockware, Inc., 1991), which produced rose diagrams and calculated the mean azimuth vectors and their confidence intervals for the minimum horizontal principal stress. Only information from the study area was used to determine the average principal stress orientations. The entire data set was analyzed by ROSE followed by a series of analyses that compared the results obtained by different measurement methods (fig. 7 and table 3).

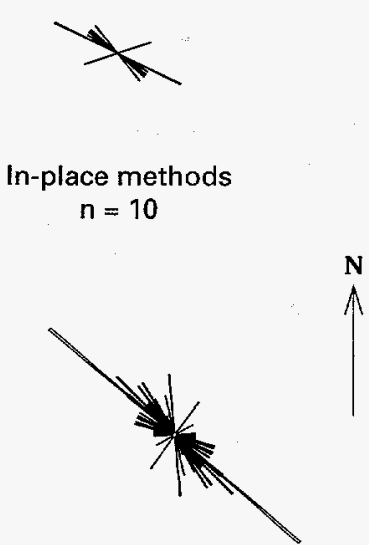

Focal mechanism method $n=89$

Geologic methods $n=14$

$\mathrm{n}=$ number of measurements

Figure 7. Minimum horizontal principal stress axes for different crustal stress measurement methods.

ROSE is a two-dimensional orientation analysis program and a member of the ROCKWORKS software system (Rockware, Inc., 1991). This software reads a listing of line endpoints and generates rose diagrams and azimuths. An azimuth is a bearing measurement in degrees clockwise from north, where north is $0^{\circ}$. Input data can be bidirectional (such as a line) or unidirectional (current directions or wind directions). The trace of a discontinuity is bidirectional data. As a result, ROSE calculates and plots two azimuths, one for each direction. This results in a symmetrical rose diagram.
Table 3. Statistical summaries of the orientation of minimum horizontal principal stress in the Death Valley region for different crustal stress measurement methods

\begin{tabular}{lcc}
\hline \multicolumn{1}{c}{$\begin{array}{c}\text { Data } \\
\text { category }\end{array}$} & $\begin{array}{c}\text { Mean vector } \\
\text { orientation } \\
\pm \text { confidence } \\
\text { interval }\end{array}$ & $\begin{array}{c}\text { Number of } \\
\text { measure- } \\
\text { menis }\end{array}$ \\
\hline All data in study area & $306^{\circ} \pm 8^{\circ}$ & 113 \\
Data from focal mechanism methods & $309^{\circ} \pm 9^{\circ}$ & 89 \\
Data from in-place methods & $302^{\circ} \pm 20^{\circ}$ & 10 \\
Data from geologic methods & $293^{\circ} \pm 20^{\circ}$ & 14 \\
\hline
\end{tabular}

Nine data points were not included in the analyses but were included in the tabulation of data for completeness. These data are marked by an asterisk $\left(^{*}\right)$ in table 2 . The seven values reported by Anderson and Ekren (1977) and two values reported by Harmsen and Bufe (1991) were not used in the study. The seven values reported by Anderson and Ekren (1977) represent paleostress directions, while Harmsen and Bufe (1991) reported two values that they feel reflect stresses induced by nuclear tests, and they suggested that these values should not be used to infer properties of the natural stress field.

Even with the removal of these questionable values, the remaining data contain variation in the estimated minimum horizontal principal stress orientations (table 3 and fig. 7). This variation may be real, reflecting changes in the stress field owing to faulting and other geologic structures or topographic effects. Regional stress states can develop local stress states that do not coincide. The variation may be due to poor measurements, analytical errors, the use of composite solutions, and differences in results produced by various solution methods (Zoback and Zoback, 1980a). Based on available data, the mean azimuth of the orientation of the minimum horizontal principal stress axis for the entire area is $306^{\circ}$ with a confidence interval of $8^{\circ}$ (table 3 and fig. 7). The geologic and in-place methods of principal stress axis orientation appear to have the most variability. These methods, however, also have the minimum amount of data.

The structural subsections defined by Carr (1990) were used to provide an appropriate subdivision of the study area and to help analyze the data shown in table 2. Although these subsections represent distinctive tectonic regimes, dramatic changes in the orientation of the principal stress 
fields at their boundaries may not exist. The presentday stress field may not reflect the stresses that produced structures that Carr used to subdivide the region. Rose diagrams of the principal stress orientation for each structural subsection are shown in figure 8 . The mean trace azimuths and confidence intervals are tabulated in table 4. ROSE (Rockware, Inc., 1991) was used to plot the rose diagrams and to calculate the mean azimuth of the minimum horizontal principal stress axis and the confidence intervals.
The structural subsections defined by Carr (1990) show apparently significant variations in principal stress orientations (fig. 8). This suggests that much of the observed variation reflects regional geologic variations rather than measurement or analytical errors. The southern part of the study area appears to have a more east-west-oriented minimum principal stress axis. Farther to the north, the orientation of the minimum principal stress axis becomes more northwest-southeast. The Pahranagat shear zone has the most variability but only a few measurements.

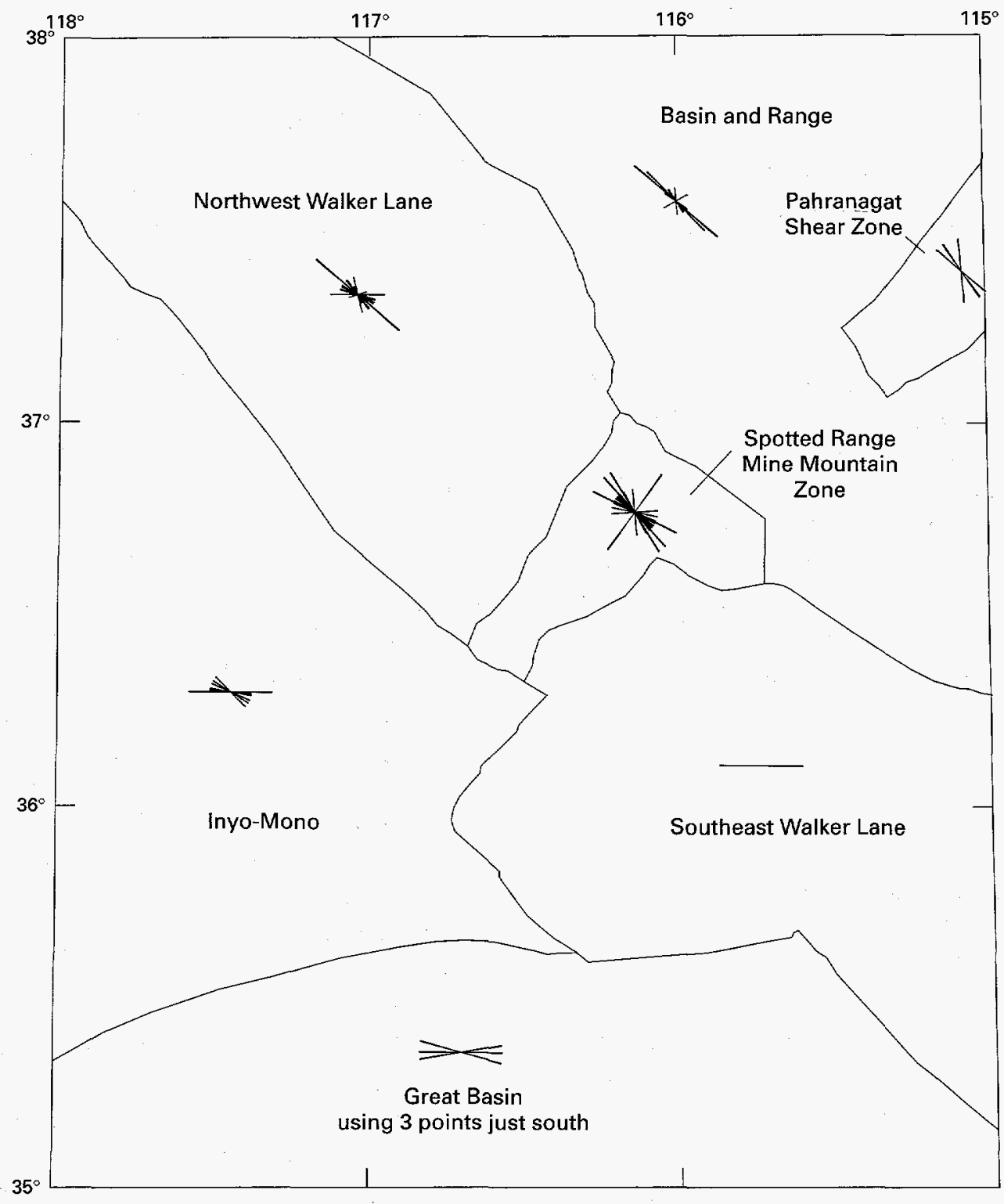

Figure 8. Minimum horizontal principal stress axes for the structural-physiographic subsections. 
Table 4. Statistical summaries of the orientation of minimum horizontal principal stress for the structuralphysiographic subsections

\begin{tabular}{lcc}
\hline \multicolumn{1}{c}{$\begin{array}{c}\text { Data } \\
\text { category }\end{array}$} & $\begin{array}{c}\text { Mean vector } \\
\text { orientation } \\
\pm \text { confidence } \\
\text { interval }\end{array}$ & $\begin{array}{c}\text { Number of } \\
\text { measure- } \\
\text { ments }\end{array}$ \\
\hline Northwest Walker Lane & $306^{\circ} \pm 11^{\circ}$ & 56 \\
Basin and Range & $313^{\circ} \pm 18^{\circ}$ & 16 \\
Pahranagat shear zone & $328^{\circ} \pm 32^{\circ}$ & 4 \\
Spotted Range-Mine & $308^{\circ} \pm 20^{\circ}$ & 25 \\
$\quad$ Mountain zone & $270^{\circ} \pm 15^{\circ}$ & 1 \\
$\begin{array}{l}\text { Southeast Walker Lane } \\
\text { Great Basin using 3 points } \\
\text { just to the south }\end{array}$ & $272^{\circ} \pm 23^{\circ}$ & 3 \\
Inyo-Mono & $285^{\circ} \pm 22^{\circ}$ & 8 \\
\hline
\end{tabular}

\section{Development of Fault-Trace Map}

Because the Death Valley region has been characterized by a long and diverse tectonic history, faulting is pervasive. The hydrogeologic conceptual model forming the basis for this study indicates that the extensive fault network and associated fractures significantly affect the ground-water flow regime. Ground-water and surface-water flows also may be controlled by structural features beneath alluvial cover. Also, the matrix conductivity inside structural zones is often higher than the matrix conductivity outside of structural zones. In this study, anomalous drainages were assumed to represent additional faults that were not mapped on existing geologic maps.

A complete digital surface-water drainage map was created by combining the drainage information from eighteen 1:100,000-scale DLG's (U.S. Geological Survey, 1989). This digital drainage map was analyzed to determine which drainages are anomalous by using techniques modified from Peter and others (1988). The following criteria were used to define significant anomalous drainages:

1. Drainage is relatively straight for more than $16 \mathrm{~km}$;

2. drainages that parallel the topographic slope or dip slope are not used unless other criteria are met;

3. discontinuous drainages must cross a drainage divide or trunk stream;

4. strike valley drainages are eliminated unless other criteria are met; and

5. cultural features are not used.
Faults shown on available published maps for the study area were scanned or digitized. These maps, defined by figure 9 , included:

1. Parts of four 1:250,000-scale geologic maps by the California Division of Mines and Geology (Jennings, 1961; Jennings and others, 1962; Strand, 1967; Streitz and Stinson, 1974);

2. part of 1:500,000-scale Nevada State Geologic Map

(Stewart and Carlson, 1978); and

3. twenty larger scale maps, ranging in scale from $1: 24,000$ to $1: 100,000$, which include essentially all available geologic maps published for the study area (see fig. 9).

A procedure for transferring map documents to a digital file format, described in Soller and others (1990), formed the basis for all data digitization. Maps showing fault traces were scanned by using a raster-tovector Tektronix scanner. This process was similar to that described by Bawiec and others (1992) during their development of the digital version of the geologic map of Nevada (Turner and Bawiec, 1991). The processing removed artifacts of the scanning process, transformed the files into a suitable geographic coordinate system, and edited the files to achieve accurate topology.

Certain criteria were used to decide which geologic information to include or exclude. Dashed contacts and faults were treated as solid lines and were not separately identified in the data base. Fault traces were encoded as simple fault lines and were not attributed with attitude or type. The map control points did not always agree with those contained on the original stable bases. To eliminate any further confusion and to produce a more geographically correct digital file, the resulting map was scaled to fit the calculated control points. The result is that the digital map will not agree exactly at all locations with the original source materials.

When available, larger scale maps were used in place of smaller scale maps (fig. 9). Faults that were not represented on the larger scale maps, but were shown on the regional maps, were added if they were longer than about $5 \mathrm{~km}$. Each trace was attributed with the map source (fig. 9). To identify the map source, the author and date of publication were placed as an attribute in the data base. 


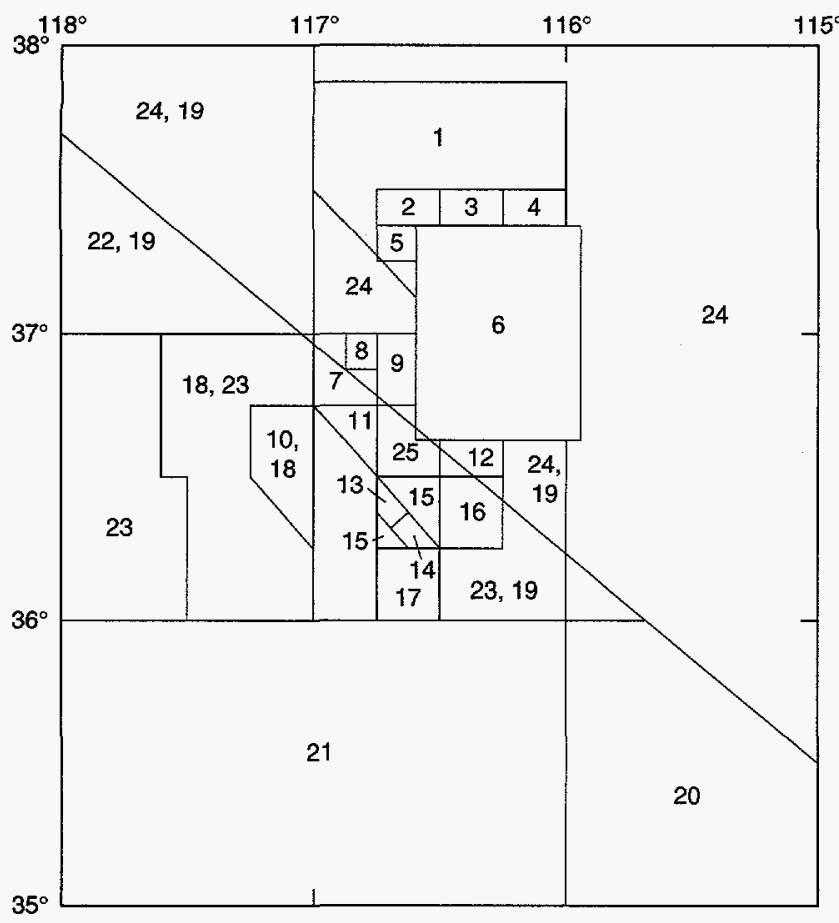

Compilation of References on Fault Mapping

\begin{tabular}{|l|c|}
\hline \multicolumn{1}{|c|}{ Reference } & Number in figure \\
\hline Ekren and others (1971) & 1 \\
\hline Rogers and others (1968) & 2 \\
\hline Orkild and others (1969) & 3 \\
\hline Sargent and Orkild (1973) & 4 \\
\hline Noble and Christiansen (1968) & 5 \\
\hline Frizzel and Shulters (1990) & 6 \\
\hline Cornwall and Kleinhampl (1961a) & 7 \\
\hline Maldonado and Hausback (1990) & 8 \\
\hline Cornwall and Kleinhampl (1961a) & 9 \\
\hline Hunt and Mabey (1966) & 10 \\
\hline Troxel and Wright (1989) & 11 \\
\hline Burchfiel (1966) & 12 \\
\hline McAllister (1970) & 13 \\
\hline McAllister (1973) & 14 \\
\hline McAllister (1971) & 15 \\
\hline Denny and Drewes (1965) & 16 \\
\hline Drewes (1963) & 17 \\
\hline Reheis (1990) & 18 \\
\hline Reheis and Noller (1990) & 19 \\
\hline Jennings (1961) & 20 \\
\hline Jennings and others (1962) & 21 \\
\hline Strand (1967) & 25 \\
\hline Streitz and Stinson (1974) & \\
\hline Stewart and Carlson (1978) & 22 \\
\hline Swadley and Carr (1987) & 3 \\
\hline
\end{tabular}

Figure 9. Fault-trace map locations. 
The more detailed maps were used in order to make sure recent faults that might indicate the stress field were included. The problem of differences in information content on maps of different scales was not addressed. Because fault distributions and orientations were compiled at various scales, a faulttrace map was constructed to show varying levels of detail of numerous regional and local geologic maps. Mapped fault traces and anomalous drainages were combined to produce the fault-trace map.

\section{Statistical Summaries of Fault Traces}

The digital information for faults and anomalous drainages was combined to produce a digital map of fault traces (fig. 10). Each of the line traces representing a fault was exported to a file containing the endpoints of the trace. These endpoints were used with ROSE (Rockware, Inc., 1991) to calculate the average azimuth of a trace.

The traces were attributed with the azimuth calculated by ROSE from the endpoint data. Because trace data are bidirectional, two azimuths are possible for each trace. Because one attribute was given for each trace, the azimuth used was taken from the western one-half of the rose diagram (values between $180^{\circ}$ and $360^{\circ}$ ). Because of software limitations, azimuth determinations were generalized and only the endpoints of faults were used. Therefore, curved faults have approximate azimuths.

Rose diagrams of the faults for all the data and each structural subsection are shown in figure 11. In addition, ROSE (Rockware, Inc., 1991) was used to calculate the mean azimuth of a trace and the confidence interval. The mean azimuths and confidence intervals are tabulated in table 5 for all the data and each structural subsection.

Figure 11 and table 5 show the orientations of faults over the study area. When all the traces in the study area are combined, the distribution is oriented north-south. The Basin and Range, Northwest Walker Lane, Southeast Walker Lane, and the Inyo-Mono subsections generally follow a similar distribution. The Pahranagat shear zone subsection appears to have a minimum of two major orientations: northeast-southwest and northwest-southeast.

The concentration of two directions at right angles to each other accounts for the large confidence interval. The fault traces in the Spotted RangeMine Mountain zone are oriented northeastsouthwest. Furthermore, this subsection has a relatively large number of traces, despite its small size. The traces located in the Great Basin subsection have a different distribution, indicating a different structural province.

\section{EFFECTS OF FAULTS ON GROUND-WATER MOVEMENT}

The procedure used to analyze the possible effects of faults and crustal stress on the regional ground-water flow system is shown in figure 12. Faults were placed into three categories based on their orientations relative to the present-day stress field: those that are in relative tension (faults parallel to maximum stress), those that are in relative compression (faults parallel to minimum stress), and those that are in shear (faults at approximately $45^{\circ}$ to maximum stress). Faults are categorized as preferential conduits or barriers to flow, depending on whether they are in tension, compression, or shear.

Review of previous studies and basic geologic principles suggested that faults in relative tension are more likely to be preferential conduits for ground water, while faults in shear or compression are more likely to deflect or block ground-water movement. Previous reviews of Death Valley regional data (Bedinger and others, 1989b) provided estimates for the effects of faulting and depths below ground surface on hydraulic properties. These estimates were useful in applying these concepts to this study.

From the above considerations, the following three principles were used in developing the hydrogeologic framework model of the Death Valley region:

1. Large-scale folding and block faulting form the major topographic features and sedimentary basins (influencing recharge and discharge areas);

2. faulting and intense folding cause fracturing and create highly permeable channels that are enhanced by dissolution in the carbonate aquifer; and 


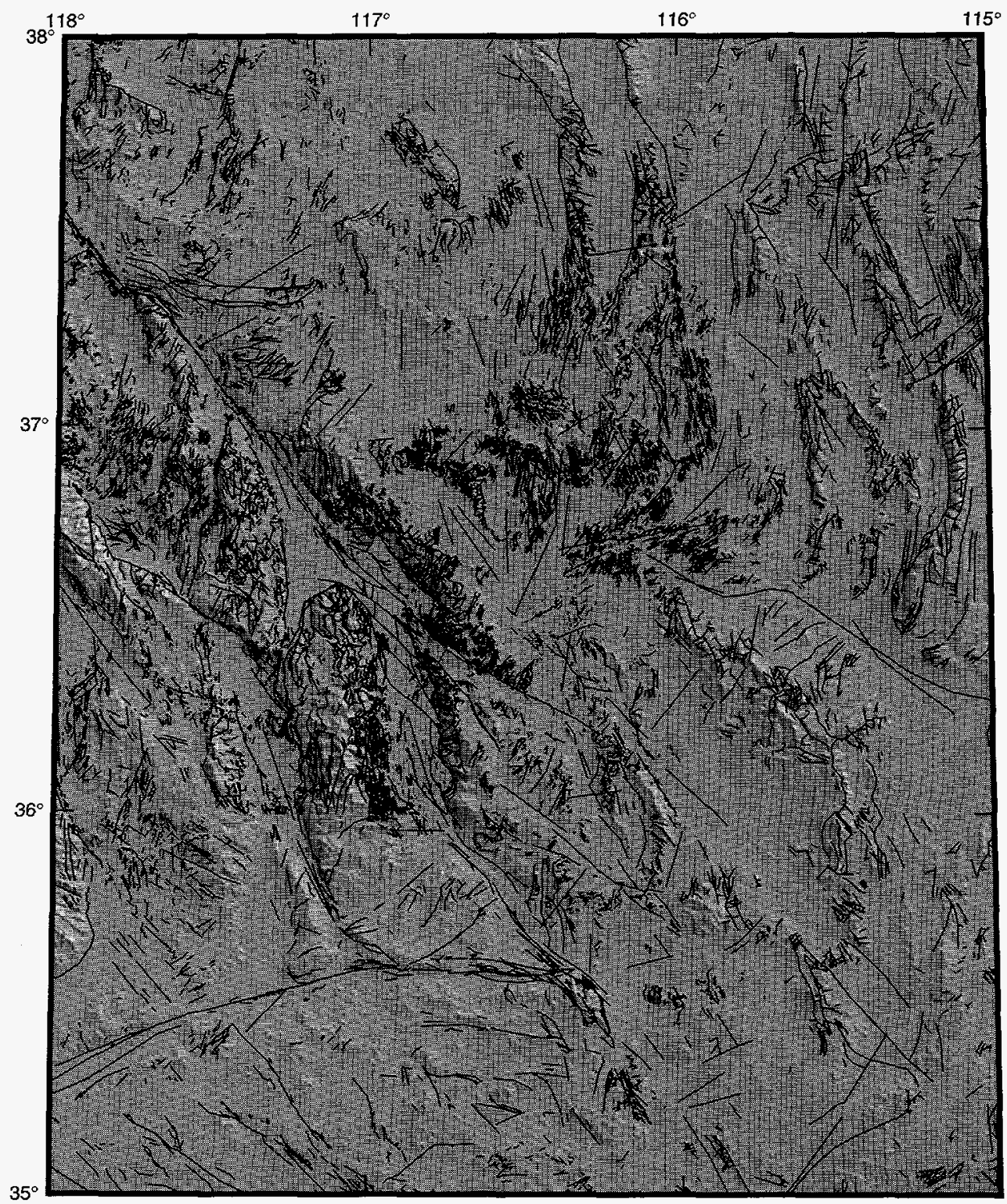

Shaded-relief base from U.S. Geological Survey digital data, 1:250,000, 1987; sun illumination from northwest at $30^{\circ}$ above horizon
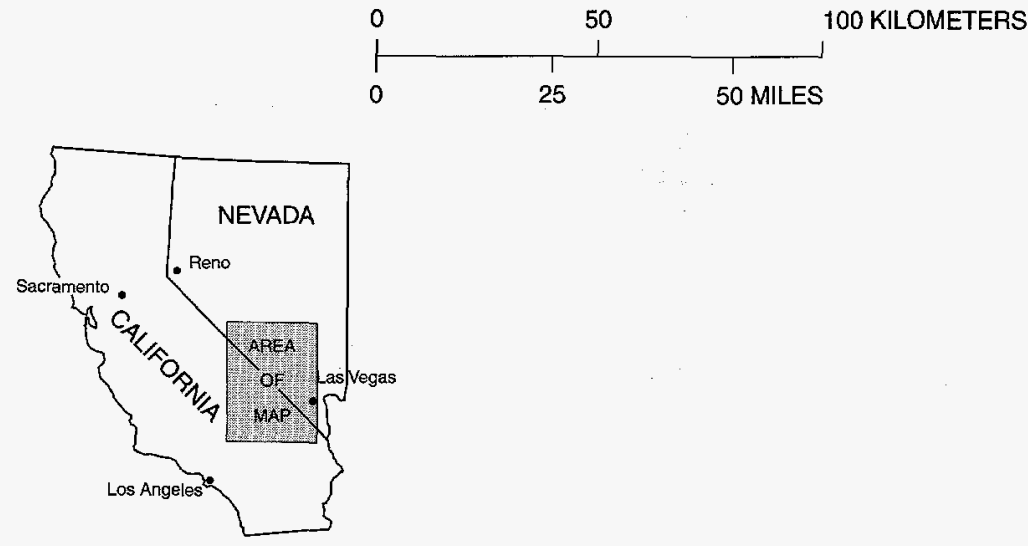

Figure 10. Fault traces of the Death Valley region. 


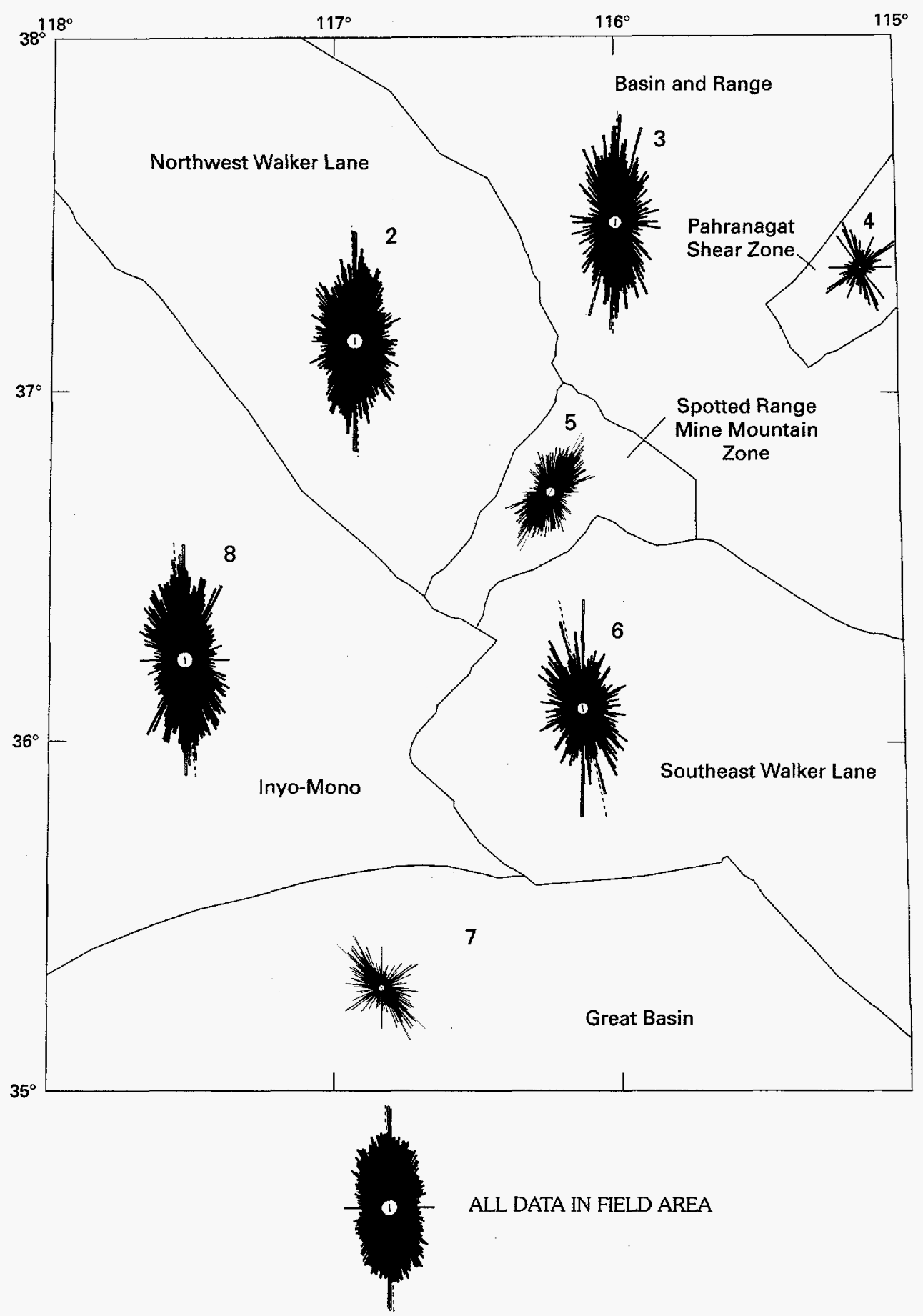

Figure 11. The distribution of the orientation of all faults. The rose diagram petals illustrate the frequency of the data. The petal length is proportional to the percentage of total number of measurements that fall within the petal. Mean orientation is shown by extended line. 
3. faulting and folding in rock types create barriers to ground-water movement due to displacing strata and create low permeability materials within faulted and fractured rocks. As a result, ground water is forced to the surface as springs and diffuse discharge.

Table 5. Orientation of fault traces

\begin{tabular}{lcr}
\hline \multicolumn{1}{c}{$\begin{array}{c}\text { Data } \\
\text { category }\end{array}$} & $\begin{array}{c}\text { Mean vector } \\
\text { orientation } \\
\pm \text { confidence } \\
\text { interval }\end{array}$ & $\begin{array}{c}\text { Number } \\
\text { of traces }\end{array}$ \\
\hline All data in study area & $358^{\circ} \pm 2^{\circ}$ & 39,783 \\
Northwest Walker Lane & $358^{\circ} \pm 3^{\circ}$ & 11,869 \\
Basin and Range & $1^{\circ} \pm 3^{\circ}$ & 4,677 \\
Pahranagat Shear Zone & $8^{\circ} \pm 16^{\circ}$ & 435 \\
Spotted Range-Mine & $27^{\circ} \pm 5^{\circ}$ & 4,055 \\
$\quad$ Mountain zone & $348^{\circ} \pm 7^{\circ}$ & 3,337 \\
Southeast Walker Lane & $314^{\circ} \pm 7^{\circ}$ & 2,580 \\
Great Basin & $355^{\circ} \pm 2^{\circ}$ & 12,830 \\
Inyo-Mono & & \\
\hline
\end{tabular}

\section{Categorization of Faults}

Basic mechanics of materials principles may be used to relate existing fault orientations to current crustal stress fields. As shown in figure 13, zones of compression, tension, and shear exhibit a definite pattern with respect to the principal stress axes. The angular limits of these zones will reflect material strength properties, but their relative orientation will always remain the same. A fracture, whose trace orientation will fall within one of these zones, will be subjected to the corresponding compression, tension, or shear conditions. In this study, all faults were simplified to vertical. One of the principal stress axes was assumed to be vertical.

The statistical summary of the available crustal stress data resulted in the definition of minimum horizontal principal stress orientations for each of the structural-physiographic subsections

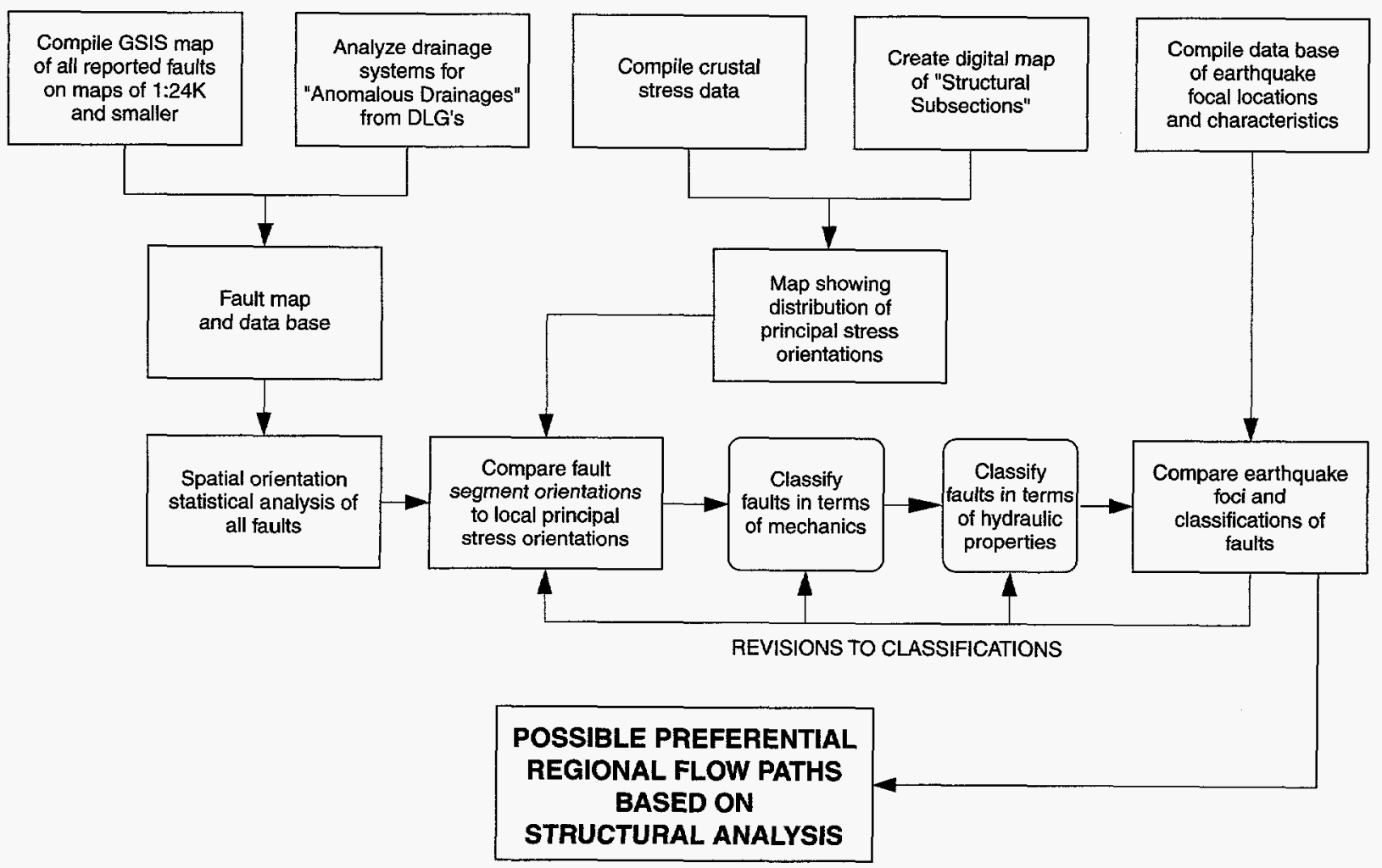

Figure 12. Methods used to process fault data. 
defined by Carr (1974). These orientations have been defined in figure 8 and table 4 . Because the Great Basin subsection exhibited a very different tectonic character, had a limited overlap with the actual Death Valley ground-water basin, and had limited data, it was not analyzed. While the Southeast Walker Lane subsection had only a single crustal stress datum, it was believed to have similar characteristics to the rest of the Walker Lane and, thus, was retained.

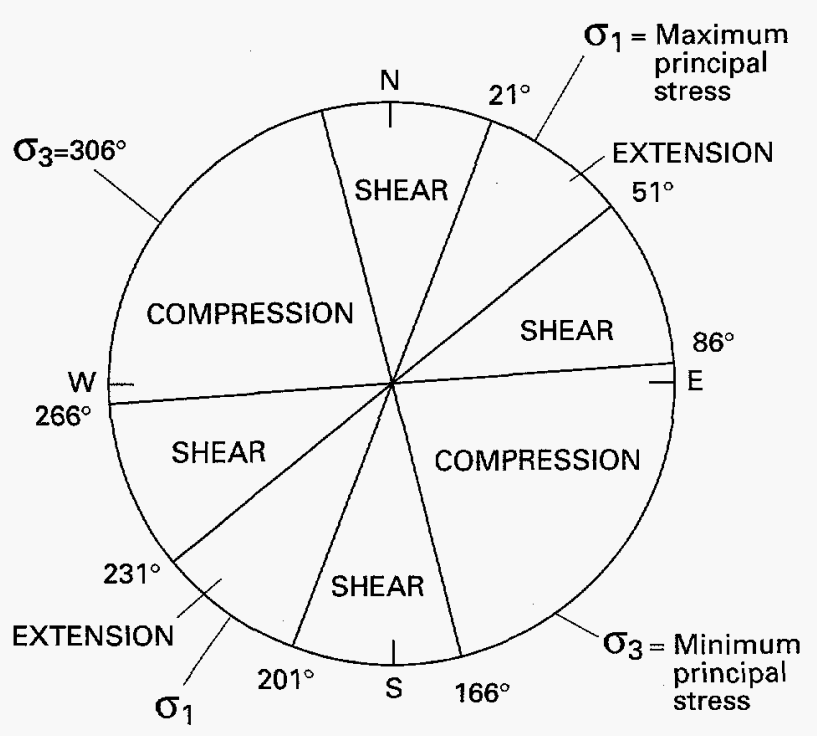

Figure 13. Orientation of mechanical state of faults using the regional average minimum horizontal principal stress axis.

The ideal model relating the principal stress axes to the zones exhibiting compression, tension, or shear (fig. 13) was combined with the mean minimum horizontal principal stress axes for each of the structural-physiographic subsections shown in table 5 to produce an oriented stress model for each subsection (figs. 13 and 14). The orientation of each fault trace shown in figure 10 was compared to the appropriately oriented stress model, and the fault was classified as being in a potential state of compression, tension, or shear. This classification was added as an attribute to the fault-trace data base, and these attributes are illustrated on plate 1 .

\section{Effects of Faults on Hydrogeology}

Faults, shear zones, and fractures largely determine the secondary water-transmitting properties of rock (Anna, 1986). Tensional structural features develop parallel to the major stress direction, while compressional structural features develop approximately perpendicular to the tensional features. Tensional structural features in rocks may enhance secondary porosity or permeability; thus, groundwater flow volumes may be greater in the general direction of the tensional features. Conversely, compressional features tend to decrease secondary porosity or permeability. Hence, these compressional features may form partial barriers that deflect the water from its original flow path or may totally block ground-water flow, causing water to discharge to the surface along spring lines or as diffuse discharge zones.

Porosity and permeability reduction due to compression and permeability enhancement due to tension are neither well documented nor fully understood. The changes may be caused by mechanical effects, or chemical reactions, or both. Furthermore, these processes may be totally effective, partially effective, or even totally ineffective, depending on the scale and other geologic, structural, climatic, and chemical factors (Anna, 1986).

To adequately assess their hydrogeologic significance, the hydrologic properties of faults should be measured directly. This requires a combination of techniques to locate faults and detailed hydrogeologic and hydrochemical measurements (Black and others, 1987). Because the hydrologic effects of faults are generally not easily observable, most geologic mapping programs do not attempt to classify faults in terms of their hydrologic effect (Black and others, 1987).

Because transmissivity, permeability, primary porosity, secondary porosity, texture, geometry, structure, and tectonics are commonly interrelated, the relationships between structure, stratigraphy, and ground-water flow characteristics are important in evaluating any ground-water system. Mechanical deformation may have different effects on ground-water flow in different rock types. Four factors affect the ability of faults to transmit water: 


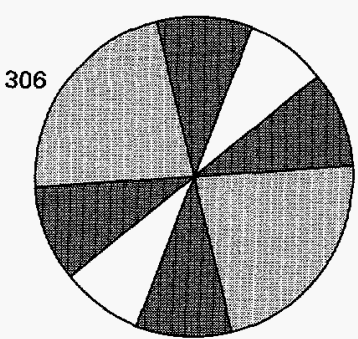

Northwest Walker Lane

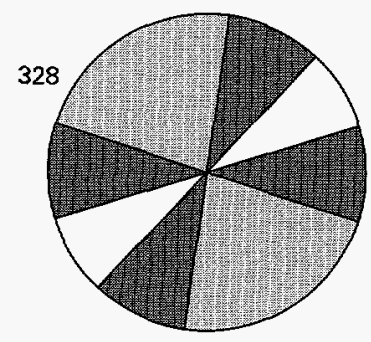

Pahranagat Shear

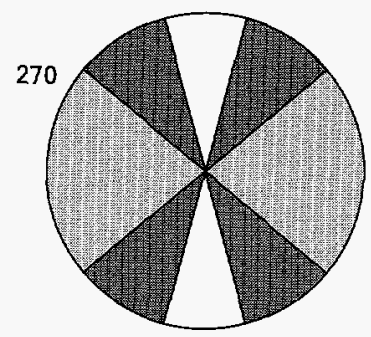

Southeast Walker Lane

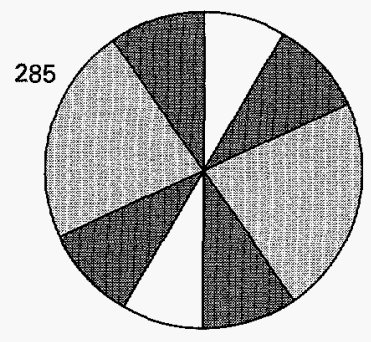

Inyo-Mono

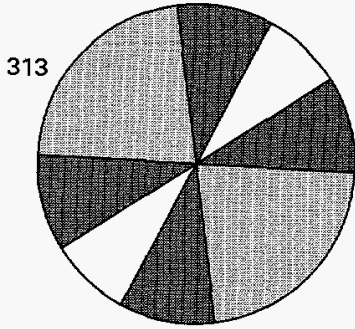

Basin and Range

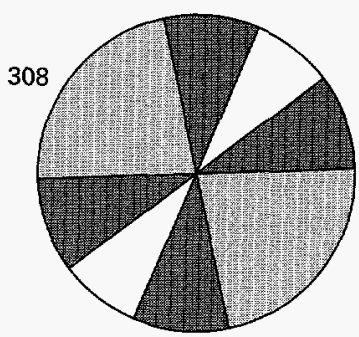

Spotted Range-Mine Mountain

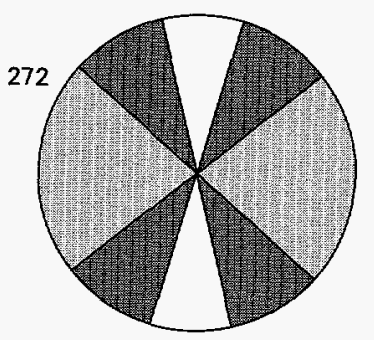

Great Basin using 3 points just to the south

\section{EXPLANATION}

\begin{tabular}{|l|l}
\hline & $\begin{array}{l}\text { Zone of compression } \\
\text { Zone of extension }\end{array}$ \\
\hline Zone of shear
\end{tabular}

Figure 14. Stress model for each subsection including azimuth for the minimum horizontal principal stress axis. 
(1) stress relationships (mechanics), (2) amount of offset, (3) amount of fracturing, and (4) material within the fault.

Anna (1986) emphasized the importance of evaluating structure and stratigraphy when analyzing either regional or local ground-water systems. Black and others (1987) suggested that faults can have two effects on ground-water flow: direct effects associated with alterations to flow rates and ground-water velocities within the faulted zone, and indirect effects associated with physical alterations to the flow field in the area near the faulted zone.

\section{Direct Effects of Faults}

Along faults, zones of fracturing and fragmentation of the rocks may form the principal paths through which most ground water flows (Dettinger, 1989). Some rock types, such as the carbonates, will have enhanced permeability because of dissolution along openings (Lattman and Parizek, 1964). This secondary permeability, in the form of fractures or dissolution features, can greatly increase the ability of a rock to transmit water. Openings that have developed in and along a fault zone may result in the fault acting as a reservoir for storage of water.

Faults can act as either preferential conduits or barriers to flow, depending upon whether the fault zones or units being juxtaposed are more or less permeable than the adjoining aquifers (Bredehoeft and others, 1992). Whether a fault is more or less permeable than its surroundings depends on:

(1) geometry of the discontinuity, (2) properties of the material in the discontinuity, (3) properties of the surrounding rocks, and (4) relationship of the discontinuity to the regional stress field (Bredehoeft and others, 1992). If a fault zone is sufficiently permeable, circulation between normally isolated aquifers can be enhanced (Fiero and others, 1974). Conversely, if permeable strata are offset or the fault zone materials are less permeable than the surrounding rocks, the flow of water will be interrupted. In either case, there may be significant differences of water level on opposite sides of the fault (Fiero and others, 1974). Winograd and Thordarson (1975) pointed out that faults within the carbonate rocks may act as hydraulic barriers, or ground-water dams, and may compartmentalize (but not necessarily totally isolate) the carbonate aquifer. In aquifers of the northern Great Plains, Anna
(1986) reported that tensional features enhance secondary porosity or permeability and become partial conduits for ground-water flow, but compressional features decrease porosity or permeability and become effective barriers or partial barriers to ground-water flow.

The Death Valley region illustrates these relationships. Carbonate aquifers can be 25 times more permeable along faults (Dettinger, 1989). Winograd and Thordarson (1975) suggested open faults in siltstones and shales may increase the bulk permeability by a factor of 10 . Fridrich and others (1994) indicated that a fault controls the large hydraulic gradient under northern Yucca Mountain. From this information, the relative changes in hydrogeologic characteristics along faults may be determined.

Figures 15 and 16 illustrate several of these concepts. Extensional movements tend to produce open ground-water conduits. Conditions most likely to lead to considerable broken rock within the fault zone, and hence increased permeability, are a combination of low-strength rocks with an extensional (tensional) stress regime (Black and others, 1987). Compressional and strike-slip fractures often result in reduced permeability or blockages of ground-water conduits; however, highly permeable zones are sometimes present along these fault zones. In the Death Valley region, faults that are interpreted to be in tension, those trending generally northeast-southwest, should have enhanced porosity and permeability and become conduits for ground-water flow. In contrast, the faults likely to be in compression, trending generally northwest-southeast, should have reduced porosity or permeability, and these are more likely to become partial barriers to ground-water flow. Faults that are open (owing to seismicity, material type, or mechanics) and are conduits to ground-water flow may end in tight or closed faults. When this happens, water may come to the surface at ground-water discharge sites (springs, marshes, enhanced stream flow, or diffuse discharge).

The seismic activity of a fault may be an important factor in determining its ability to transnit water. The distance of earthquake foci from faults rnay relate to their relative activities. If a fault is active, it is more likely to have increased permeability. Accordingly, more active faults are probably more permeable. 


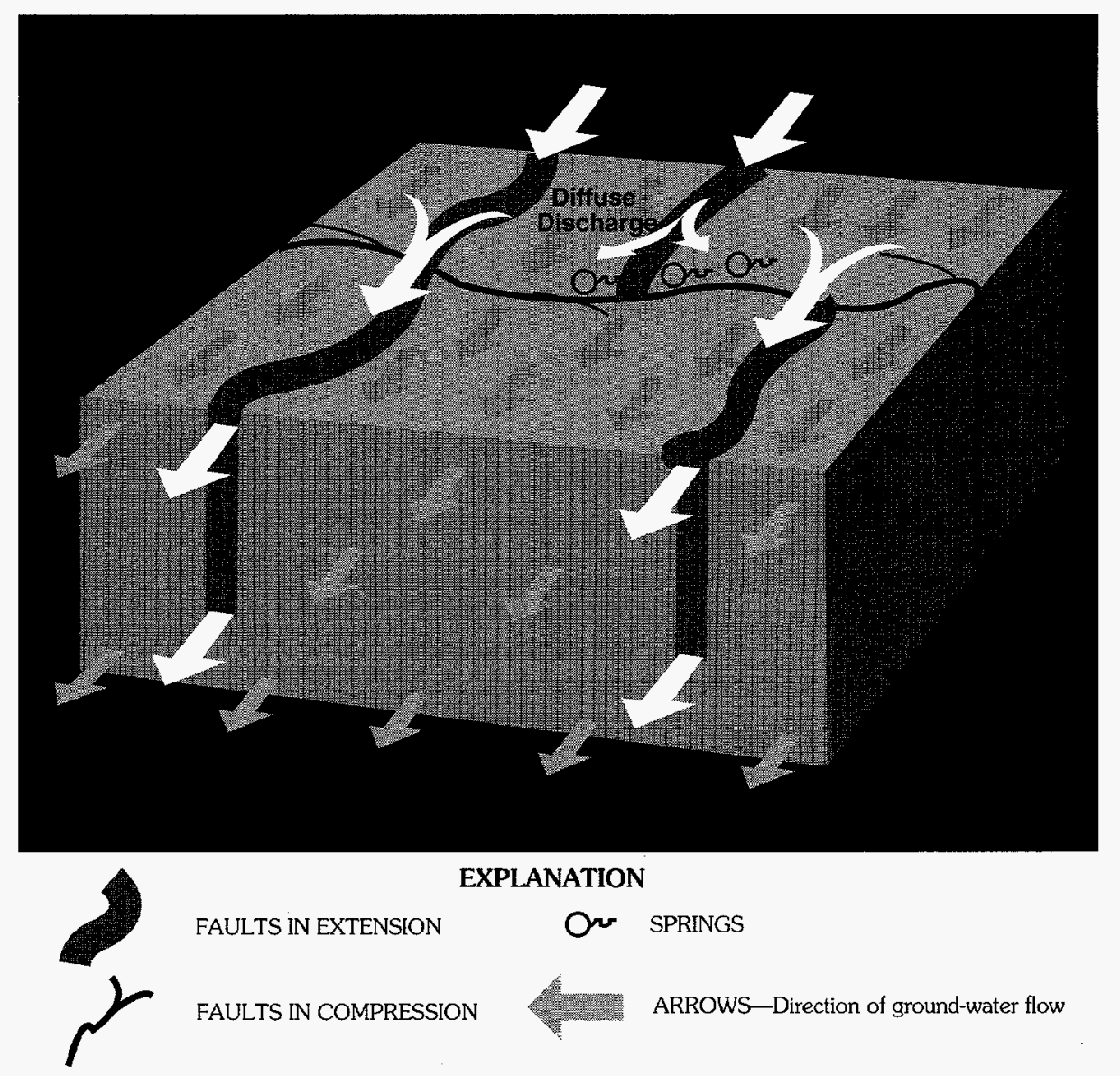

Figure 15. Theoretical ground-water flow paths (plan view). Theoretical fault zones are modified from Anna (1986).

Consequently, seismicity data may be combined with fault orientation and regional stress data to further assess the ability of individual faults to affect ground-water flow. The distance of earthquake foci from faults may reflect the activities of the faults. Recently active faults and the epicenters for earthquakes for most of the study area are shown in figure 17.

\section{Indirect Effects of Faults}

The hydrogeologic conditions also may be affected by units that are offset and how the rocks behave after faulting. The amount of offset and the type of juxtaposition of lithologic types also will affect the permeability and flow of the system. Winograd and Thordarson (1975) stated that the hydraulic gradients in the study area may be steplike rather than smooth, as fault zones may locally compartmentalize the carbonate aquifer. Interbasin movement of ground water within the carbonate aquifer is greatly influenced by major geologic structures, particularly by folds that bring the relatively impermeable clastic rocks to the surface or by faults that juxtapose the clastics and the carbonate aquifer.

Faulting may decrease the effective anisotropy of a sequence of mixed sedimentary rocks, resulting in smaller scale flow systems. Fault activation may cause significant leakage along fault planes. The magnitude of any such effects will depend on the initial hydraulic properties of each formation and the local faultinduced changes in permeability values (Black and others, 1987). 

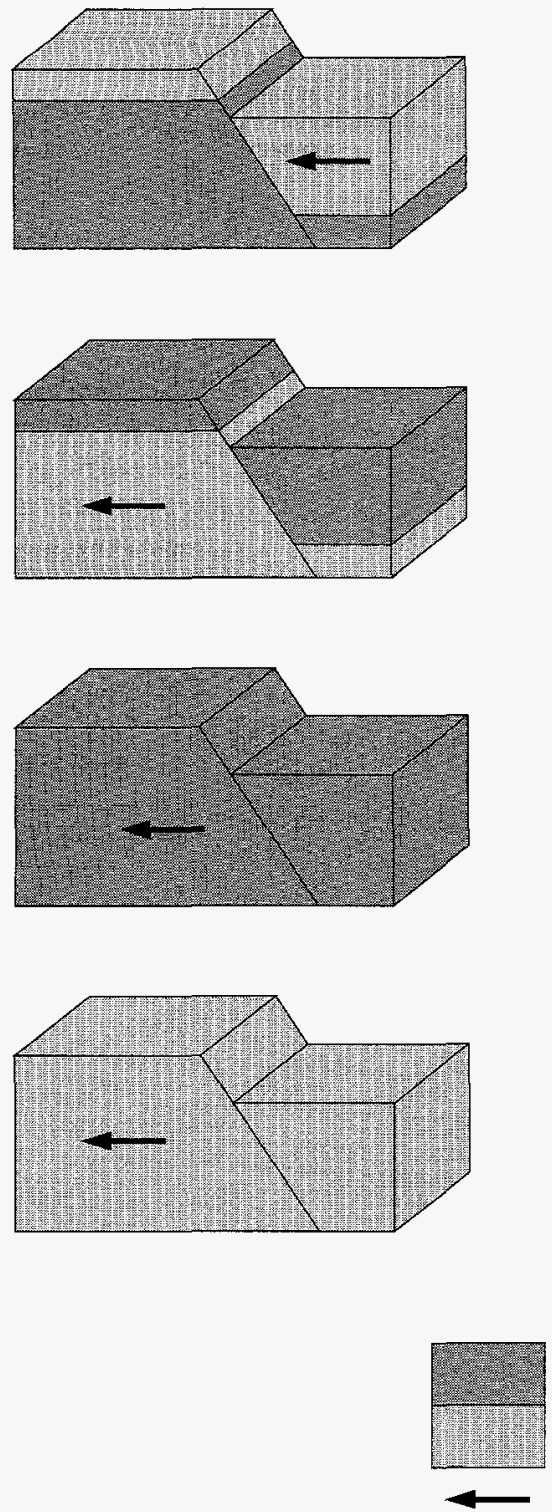

OPEN FAULT-Springs along fault or flow changes direction along fault; depending on permeability contrast, there may be a large drop in head

CLOSED FAULT_-Springs or diffuse discharge upstream from fault

OPEN FAULT_Large drop in head across fault or, depending on permeability contrast, flow may change along fault

CLOSED FAULT_-If fault is less permeable than unit, there may be some springs or diffuse discharge upstream from fault; large drop in head across fault

OPEN FAULT_-Flow along fault or springs along fault line, possibly a large drop in head at and/or across fault

CLOSED FAULT_Springs or diffuse discharge upstream from fault

OPEN FAULT_If fault is more permeable than unit, possible flow along fault and/or springs along fault line; possible negligible effect

CLOSED FAULT-If fault is less permeable than unit, there may be some springs or diffuse discharge upstream from fault; large drop in head across fault

\section{EXPLANATION}

\section{RELATIVELY LOW PERMEABILITY}

RELATIVELY HIGH PERMEABILITY

DIRECTION OF GROUND-WATER FLOW

Figure 16. Theoretical ground-water flow variations in relation to faults.

\section{Relation of Hydraulic Properties to Depth and Faulting in the Death Valley Region}

Recent hydrogeologic investigations in the study area have not included any quantitative assessment of the hydraulic role of faults. As a result, little quantitative information is available concerning the influence of regional fault zones on ground-water flow patterns. However, the conceptual model used by this study indicates that regional fault zones may have a considerable effect on the regional ground-water flow system.
Bedinger and others (1989b) believed that the Death Valley regional ground-water flow system is affected by deep ground-water flow paths. They examined the effects of depth on the hydraulic properties of the hydrogeologic framework in the Death Valley region and suggested that increased jointing near the surface, caused by stress release from erosional unloading and weathering, may yield larger permeability and porosity values for rocks at shallow depths. However, Bedinger and others (1989b) found that adequate quantitative data were not available in the Death Valley region. Most existing well-yield and 


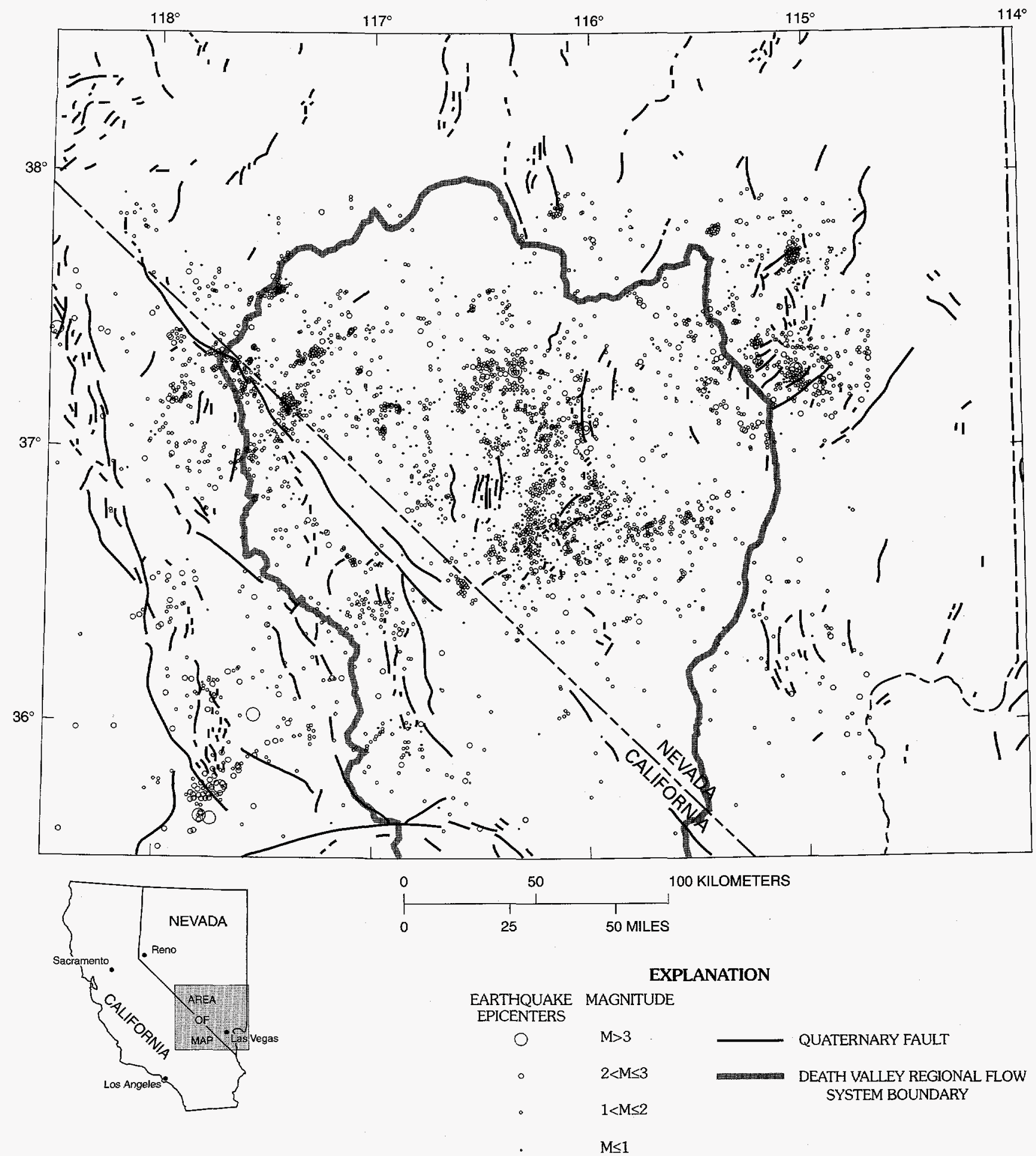

Figure 17. Quaternary faults and epicenters for earthquakes occurring from August 1978 through December 1986 in the southern Great Basin (from Hildenbrand and others, 1988). 
specific-capacity tests relate to relatively shallow depths in alluvial aquifers (Bedinger and others, 1989b). Constrained by these limitations, Bedinger and others searched for and evaluated all available hydraulic property data from a variety of locations. By comparison, with known regional geologic conditions, these results were used to estimate hydrologic properties in the Death Valley region. Bedinger and others $(1989 \mathrm{~b})$ reached the following conclusions:

1. At depths below 150 to $300 \mathrm{~m}$, weathering and fractures owing to release of confining pressures by erosional unloading probably are not significant.

2. At increased depths, overburden pressures may tend to decrease the apertures of joints or fractures and the size of pores; therefore, porosity and intrinsic permeability tend to decrease.

3. In some places, solution-type voids and relict cavernous conditions may withstand overburden pressures in crystalline carbonate rocks, allowing these features to remain open at depths up to 2,000 to $3,000 \mathrm{~m}$ and more.

4. Surface faults and fractures indicate the orientation and position of large permeability zones.

5. Large, regional, crustal fault zones indicate areas of significant increased permeability at great depths. The regional fracture permeability depends not only on the presence of fractures, but also on rock type, fracture orientation, and the history of tectonic stress in the region.

\section{Examples of Faults Affecting the Hydrogeology in the Death Valley Region}

Most spring and discharge features are associated with faults. Springs in Ash Meadows occur along fault zones (pl. 1, A; fig. 20). Springs in the Pahrump Valley occur upgradient from fault blocks. Many diffuse discharge areas are apparently associated with structural control. Many valleys in the study area have discharging playas that are the result of water being constricted in the valleys by fault-bounded mountain blocks. Alkali Flat (pl. 1, B) is an area of diffuse discharge where the flow is constricted into a narrow channel by bounding mountain ranges (Czarnecki, 1990). The diffuse discharge along the Amargosa
River in this area occurs just upstream from a mountain block (pl. 1, C; fig. 18). In Death Valley, water also comes to the surface along Salt Creek owing to a horst structure of lower permeability material (pl. 1, D; fig. 19).

Waddell (1982) described a structural feature below Fortymile Canyon that extends into the Amargosa Valley. Contour lines representing the potentiometric surface point upgradient into the canyon. These effects are attributed to increased permeability in the direction of the fractures that are parallel to the north-trending normal faults that created the graben (pl. 1, E). Carr (1984) stated that the location of the canyon is controlled by the axis of a syncline and not by faulting. Such a structure, however, also could control ground-water movement.

In the Death Valley region, regional faults generally trending northwest are in compression. In many locations, these apparently have reduced porosity or permeability and become partial barriers to ground-water flow (figs. 15 and 16). Springs commonly issue just upgradient from these compressional faults. Examples are found along the Las Vegas Valley shear zone, where there are springs upgradient on either side of the shear zone (pl. 1, F), and along the Death Valley fault zone (pl. 1, G).

Faults trending northeast generally are in tension. These should have enhanced porosity and permeability and may be partial conduits for groundwater flow. Modifications to the ground-water flow system due to tensional features are not as clearly defined on the surface because they generally are not associated with discharge features. However, the potentiometric surface reflects the effects of differing thicknesses and permeabilities of aquifers and confining units and the effects of faults on flow paths and rates. Tensional mechanics may increase permeabilities to such a degree that the associated clogging of fractures by precipitation of secondary minerals cannot completely compensate for such openings, and a net increase in permeability can be observed along these zones. Thus, in some areas, the contour lines representing the potentiometric surface point upgradient along tensional zones.

For example, the Spotted Range-Mine Mountain shear zone acts as a tensional zone draining the adjacent area and as a high permeability zone (pl. $1, \mathrm{H})$. The southwestward-trending major potentiometric trough includes the most transmissive 

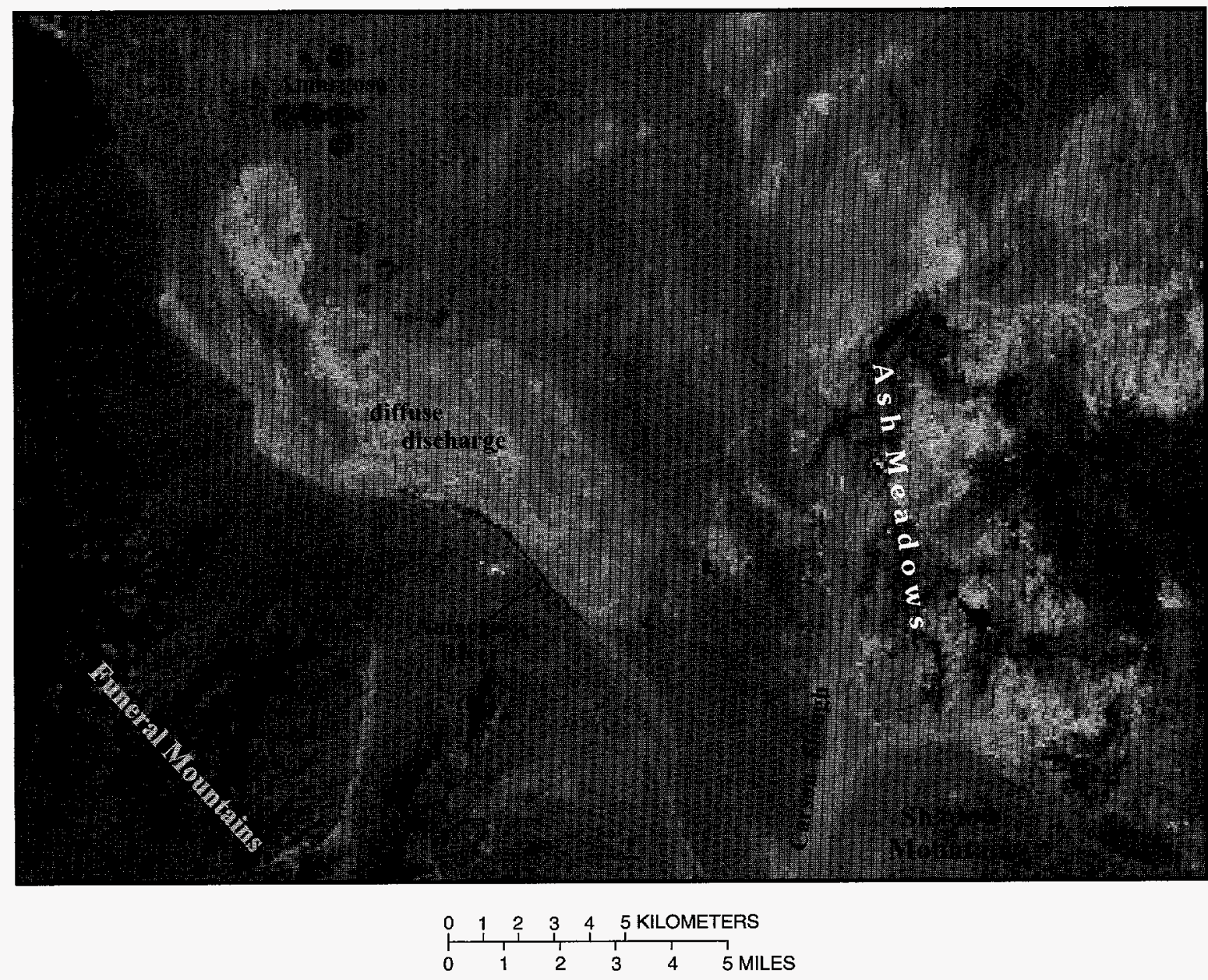

Figure 18. Diffuse discharge along the Amargosa River.

portion of the Paleozoic carbonate rocks (Winograd and Pearson, 1976). Seismic activity and Quaternary faulting are concentrated along this zone (Carr, 1984; Hildenbrand and others, 1988). The importance of this zone is highlighted by the fact that most of the rocks in the zone consist of thick, highly fractured Paleozoic carbonate rocks, the principal regional aquifer (Winograd and Thordarson, 1975). Winograd and Pearson (1976) discussed the presence of "megachanneling" in the southwestern portion of this area. The relatively large permeability within the carbonate aquifer in this area may be a consequence of continuing tectonic activity and the northeast trend of the faults, perpendicular to the minimum principal stress direction (Carr, 1974, 1984).
Even though the Walker Lane Belt trends northwest-southeast, numerous important northeasttrending structural zones occur. Carr (1984) suggested that several northeast-striking structural zones extend from northern Death Valley. These somewhat less defined features may affect regional ground-water flow by containing highly fractured, highly permeable rocks through which ground water may flow (Carr, 1984). These smaller features include: (1) northeaststriking structural lineaments from the Bullfrog Hills across the Timber Mountain Caldera (pl. 1, Ia), (2) a similar trend from southern Sarcobatus Flat to Black Mountain (pl. 1, Ib), and (3) a structural topographic trend northeastward from Death Valley through the Gold Mountain-Slate Ridge area to Stonewall Flat (pl. 1, Ic). 


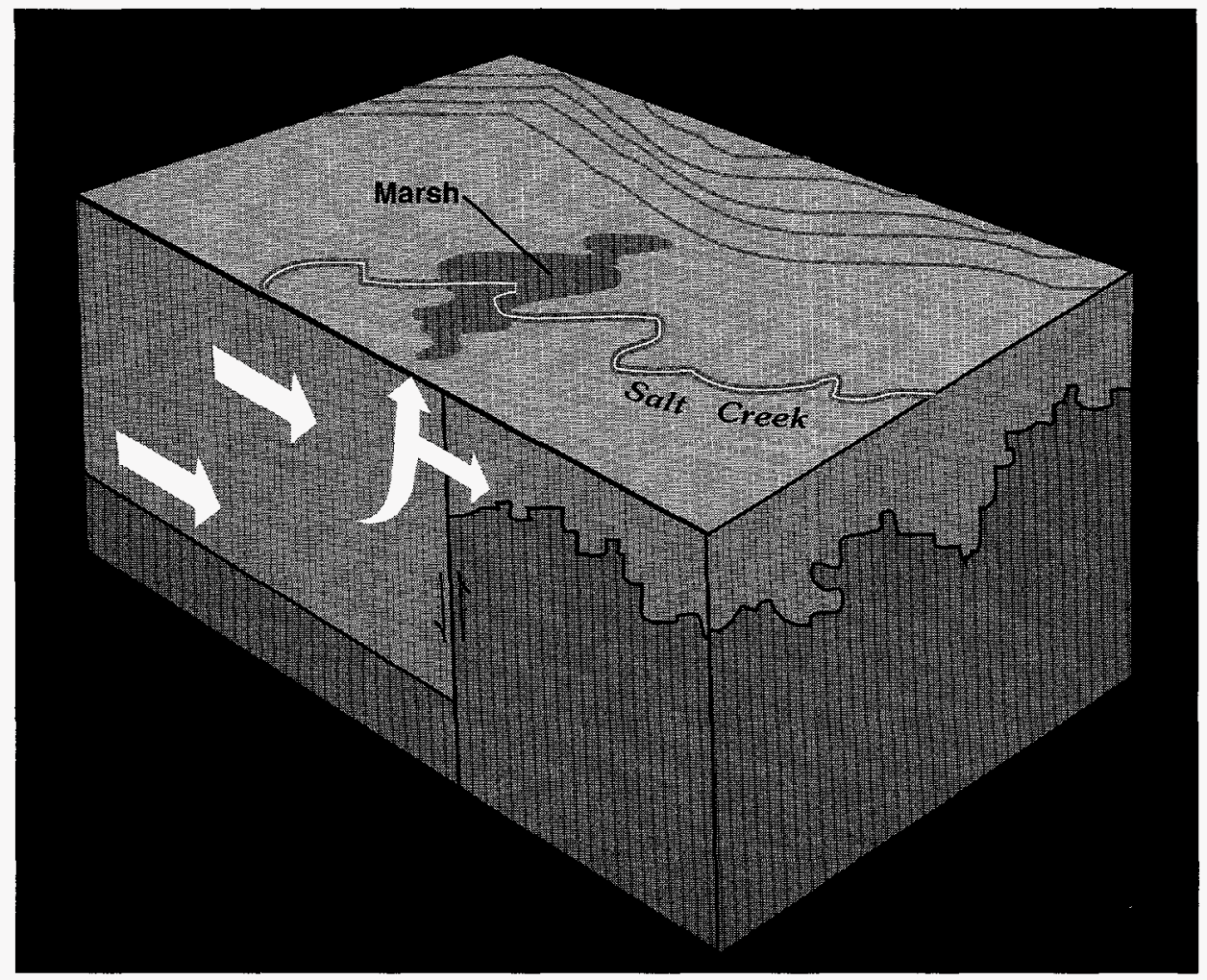

Figure 19. Structural control on ground-water flow near Salt Creek.

The area of possible infiow to the Death Valley ground-water basin from the White River ground-water basin coincides with the Pahranagat shear zone (pl. 1, J). This zone is oriented northeastsouthwest and contains numerous faults that would be in tension under the present stress regime. The faults may drain the water to the southwest into the Spotted Range-Mine Mountain zone (pl. $1, \mathrm{H})$.

Intersection of tensional and compressional discontinuities occurs at Ash Meadows (fig. 20). Numerous springs are aligned in a northwest trend. These springs occur where northeast tensional faults abut a buried northwest-trending high-angle fault. This northwest-trending fault acts as a barrier to ground-water flow. Devils Hole, a small pond approximately $3 \mathrm{~m}$ wide and $20 \mathrm{~m}$ long, is located along a northeast-trending (tensional) fault of Cenozoic age (Rojstaczer, 1987). The current minimum principal stress direction is oriented normal to this fault and may help keep this fault open. Additionally, pool stage records collected since 1962 indicate that the waterfilled fault is sensitive to seismic waves (Galloway, 1993).

Seismic activity and Quaternary faulting appear to be concentrated along this zone (Carr, 1984; Hildenbrand and others, 1988). The importance of this zone is highlighted by the fact that most of the rocks in the zone consist of thick, highly fractured, Paleozoic carbonate rocks, the principal regional aquifer (Winograd and Thordarson, 1975). The relatively large permeability within the carbonate aquifer in this zone may be a consequence of continuing seismic activity and the northeast trend of the faults, which is perpendicular to the minimum principal stress direction (Carr, 1974, 1984). The potentiometric surface points upgradient along this zone and reflects the effects of the zone on flow paths and rates. The tensional mechanics appear to cause increases in permeability that overcome any potential for clogging of fractures by precipitation of secondary minerals. 


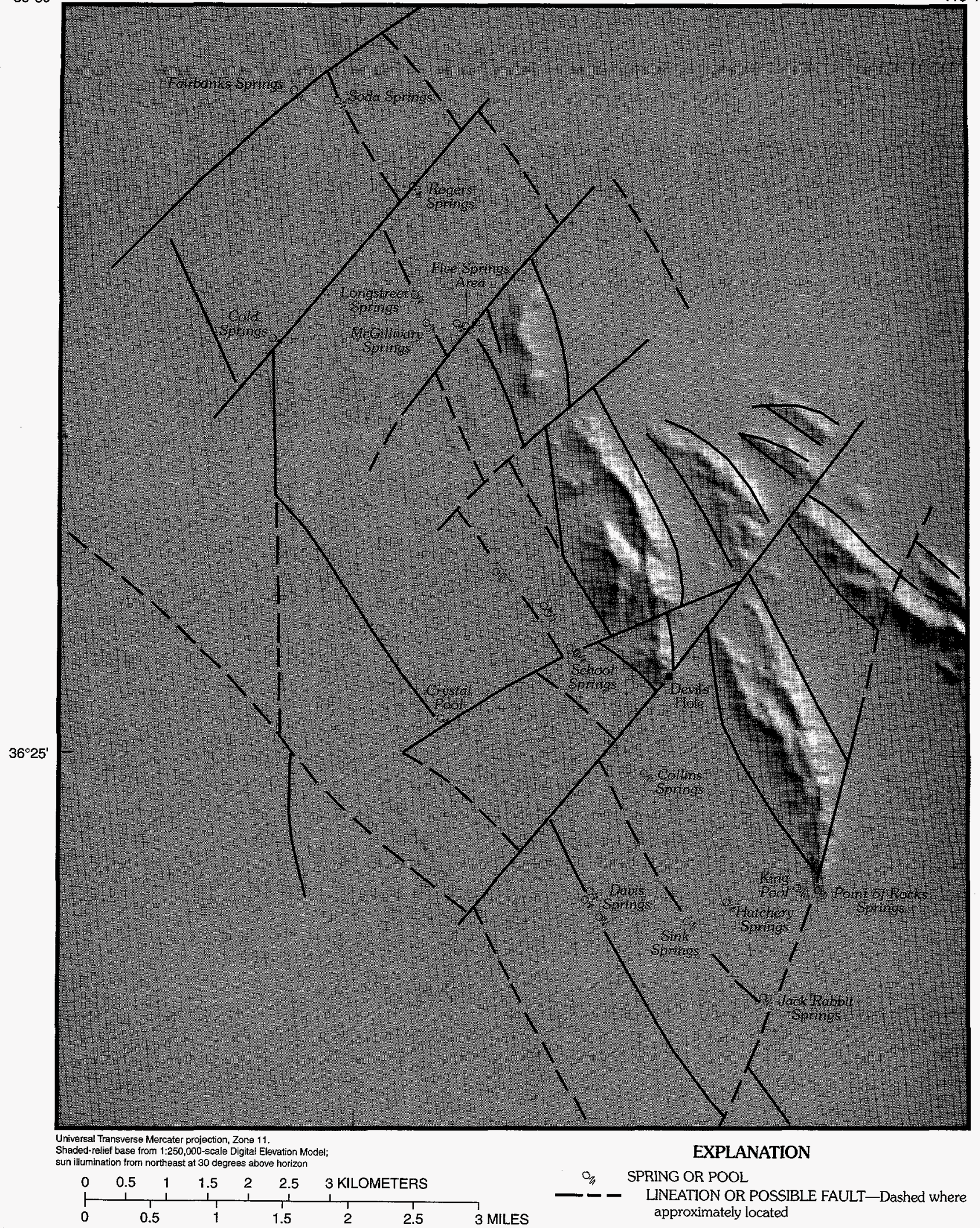

Figure 20. Relative location of springs to lineations and possible faults in Ash Meadows and vicinity (from Dudley and Larson, 1976). 


\section{SUMMARY}

Yucca Mountain, in southern Nevada, is being considered as a potential site for the storage of highlevel nuclear waste in an underground mined geologic repository. Because of the potential for radionuclides to be transported by ground water from the repository to the accessible environment, studies are being conducted to characterize the Death Valley regional flow system of which Yucca Mountain is a part.

The hydrogeologic conceptual model of the Death Valley regional ground-water flow system identifies the importance of regional tectonics in defining the character of the system. Large, interbasinal, ground-water flow systems occur in the region. Such water movements reflect regional structures.

Knowledge of the current crustal stress field is important to any evaluation of the hydrologic controls exerted by any geologic structures. Structuralphysiographic subsections provided a convenient means of describing the areal variations in tectonic regimes.

A suitable digital fault-trace map was developed for the Death Valley region by combining fault traces shown on numerous geologic maps at various scales with an interpretation of "anomalous drainages" revealed from an analysis of hydrographic data maps. Such anomalous drainages are believed to represent previously unmapped regional fault or fracture zones in a region whose long and complex tectonic history has led to pervasive fracturing.

Possible effects of faults on the regional groundwater flow regime were evaluated by comparing the crustal stress fields with the fault-trace orientations. By such comparisons, faults were placed into three categories representing their orientations relative to the present-day stress field: those that are in relative tension, those that are in relative compression, and those that are in shear. Faults are either preferential conduits or barriers to flow, depending on whether they are in tension, compression, or shear, and on other factors such as the geometrical dislocations of geologic units caused by faulting, the rock types involved, the material in the fault zone, and the depth below the surface.

Faults in relative tension are believed more likely to be preferential conduits for ground water, and faults in shear or compression may be more likely to deflect or block ground-water movements. Previous reviews of the Death Valley regional data provided estimates for the effects of faulting and depths below ground surface on hydraulic properties. These estimates were useful in applying these concepts to this study.

From the above considerations, the following three principles were used in developing the hydrogeologic framework model of the Death Valley region:

1. Large-scale folding and block faulting form the major topographic features and sedimentary basins (influencing recharge and discharge areas);

2. faulting and intense folding cause fracturing and create highly permeable channels that are enhanced by dissolution in the carbonate aquifer; and

3. faulting and folding in rock types create barriers to ground-water movement due to displacing strata and create low permeability materials within. faulted and fractured rocks. As a result, ground water is forced to the surface as springs and diffuse discharge.

Several examples of the operation of one or more of these principles are found within the Death Valley region. Such demonstrations of the effects of faulting on the regional hydrogeologic flow system indicate the importance of incorporating the faults into the digital three-dimensional hydrogeologic framework model.

The hydrogeologic characteristics estimated by this study are conceptual. While based on the best existing information, they need to be further tested. Ground-water flow models and hydrochemical data and models could be used to test the accuracy of these estimates. However, to definitively assess the hydrogeologic significance of faults, their hydrologic properties need to be measured directly.

\section{REFERENCES CITED}

Anderson, R.E., 1973, Large-magnitude late Tertiary strike-slip faulting north of Lake Mead, Nevada: U.S. Geological Survey Professional Paper 794, 18 p.

Anderson, R.E., and Ekren, E.B., 1977, Late Cenozoic fault patterns and stress fields in the Great Basin and westward displacement of the Sierra Nevada blockComment and reply: Geology, v. 5, p. 388-392.

Anna, L.O., 1986, Geologic framework of the ground-water flow system in Jurassic and Cretaceous rocks, northern Great Plains: U.S. Geological Survey Professional Paper 1402-B, 36 p. 
Bawiec, W.J., Traudt, D.K., Ambroziak, R.A., and Arndt, R.E., 1992, The evolution of a digital geologic coverage-From paper to CD-ROM: U.S. Geological Survey Bulletin 2016, chap. E, p. E1-E8.

Bedinger, M.S., Langer, W.H., and Reed, J.E., 1989a, Ground-water hydrology, in Bedinger, M.S., Sargent, K.A., and Langer, W.H., eds., Studies of geology and hydrology in the Basin and Range Province, Southwestern United States, for isolation of high-level radioactive waste- Characterization of the Death Valley region, Nevada and California: U.S. Geological Survey Professional Paper 1370-F, p. F28-F35.

$1989 \mathrm{~b}$, Hydraulic properties of rocks in the Basin and Range Province, in Bedinger, M.S., Sargent, K.A., Langer, W.H., Sherman, F.B., Reed, J.E., and Brady, B.T., eds., Studies of geology and hydrology in the Basin and Range Province, Southwestern United States, for isolation of high-level radioactive waste-Basis of characterization and evaluation: U.S. Geological Survey Professional Paper 1370-A, p. A16-A18.

Bedinger, M.S., Sargent, K.A., and Langer, W.H., 1989c, Studies of geology and hydrology in the Basin and Range Province, Southwestern United States, for isolation of high-level radioactive wasteCharacterization of the Death Valley region, Nevada and California: U.S. Geological Survey Professional Paper 1370-F, $49 \mathrm{p}$.

Black, J.H., Alexander, J., Jackson, P.D., Kimbell, G.S., and Lake, R.D., 1987, The role of faults in the hydrogeological environment: Report of Fluid Processes Research Group, British Geological Survey, 54 p. Bredehoeft, J.D., Belitz, K., and Sharp-Hansen, S., 1992, The hydrodynamics of the Big Horn Basin-A study of the role of faults: The American Association of Petroleum Geologists Bulletin, v. 76, no. 4, p. 530-546.

Bucknam, R.C., 1973, Some factors relevant to the determination of in-situ stress by analysis of geological and geophysical data: U.S. Geological Survey Report 474-168, $24 \mathrm{p}$.

Burbey, T.J., and Prudic, D.E., 1991, Conceptual evaluation of regional ground-water flow in the carbonate-rock province of the Great Basin, Nevada, Utah, and adjacent states: U.S. Geological Survey Professional Paper 1409-D, $84 \mathrm{p}$.

Burchfiel, B.C., 1966, Reconnaissance geologic map of the Lathrop Wells 15-minute quadrangle, Nye County, Nevada: U.S. Geological Survey Miscellaneous Investigations Series Map I-474, scale 1:62,500, 1 sheet.

Burchfiel, B.C., and Davis, G.A., 1981, Mojave desert and environs, in Ernst, W.G., ed., The geotectonic development of California, Rubey v. 1: Englewood Cliffs, New Jersey, Prentice-Hall, p. 217-252.
Carr, W.J., 1974, Summary of tectonic and structural evidence for stress orientation at the Nevada Test Site: U.S. Geological Survey Open-File Report 74-176, $53 \mathrm{p}$.

1982, Structural setting and rate of tectonic activity in the Yucca Mountain region, southwestern Great Basin, Nevada and California: EOS, v. 63, no. 45, p. 1-15. 1984, Regional structural setting of Yucca Mountain, southwestern Nevada, and late Cenozoic rates of tectonic activity in part of the southwestern Great Basin, Nevada and California: U.S. Geological Survey Open-File Report 84-854, $114 \mathrm{p}$.

1988, Volcano-tectonic setting of Yucca Mountain and Crater Flat, southwestern Nevada, in Carr, M.D., and Yount, J.C., eds., Geologic and hydrologic investigations of a potential nuclear waste disposal site at Yucca Mountain, southern Nevada: U.S. Geological Survey Bulletin 1790, p. 35-50.

1990 , Styles of extension in the Nevada Test Site region, southern Walker Lane Belt-An integration of volcano-tectonic and detachment fault models, in Wernicke, B.P., ed., Basin and Range extensional tectonics near the latitude of Las Vegas, Nevada: Boulder, Colo., Geological Society of America Memoir 176.

Cornwall, H.R., and Kleinhampl, F.J., 1961a, Preliminary geologic map and sections of the Bullfrog Quadrangle, Nevada-California: U.S. Geological Survey Mineral Investigations Field Studies Map MF-177, scale $1: 48,000,1$ sheet. 1961b, Geology of the Bare Mountain Quadrangle, Nevada: U.S. Geological Survey Geologic Quadrangle Map GQ-157, scale 1:62,500, 1 sheet.

Czarnecki, J.B., 1990, Geohydrology and evapotranspiration at Franklin Lake Playa, Inyo County, California: U.S. Geological Survey Open-File Report 90-356, $96 \mathrm{p}$.

D'Agnese, F.A., Faunt, C.C., and Turner, A.K., in press, An estimated potentiometric surface of the Death Valley region, Nevada and California, developed using geographic information system and automated interpolation techniques: U.S. Geological Survey WaterResources Investigations Report 97-4052.

Denny, C.S., and Drewes, Harold, 1965, Geology of the Ash Meadows Quadrangle Nevada-California: U.S. Geological Survey Bulletin 1181-L, 56 p.

Dettinger, M.D., 1989, Distribution of carbonate-rock aquifers in southern Nevada and the potential for their development-Summary of findings: Carson City, Nev., 1985-88, Program for the study and testing of carbonate-rock aquifers in eastern and southern Nevada, Summary report $1,37 \mathrm{p}$. 
Dickinson, W.R., and Snyder, W.S., 1979, Geometry of triple junctions related to the San Andreas transform: Journal of Geophysical Research, v. 84, p. 561-572.

Downey J.S., Kolm, K.E., and Gutentag, E.D., 1990, Selection of geohydrologic boundaries for groundwater flow models: Waste Management ' 90 , v. 2, p. 725-734.

Dudley Jr., W.W., and Larson, J.D., 1976, Effects of irrigation pumping on desert pupfish habitats in Ash Meadows, Nye County, Nevada: U.S. Geological Survey Professional Paper 927, 52 p.

Drewes, Harald, 1963, Geologic map of the Funeral Peak quadrangle, California: U.S. Geological Survey Professional Paper 413, pl. 1.

Eakin, T.E., Price, Don, and Harrill, J.R., 1976, Summary appraisals of the Nation's ground-water resources Great Basin region: U.S. Geological Survey Professional Paper 813-G, $37 \mathrm{p}$.

Ekren, E.B., Anderson, R.E., Rogers, C.L., and Noble, D.C., 1971, Geologic and Bouguer gravity map and sections of the northern part of Nellis Air Force Base Bombing and Gunnery Range, Nye County, Nevada: U.S. Geological Survey Professional Paper 651, pl. 1.

Ellis, W.L., and Magner, J.E., 1980, Compilation of results of three-dimensional stress determinations made in Rainier and Aqueduct Mesas, Nevada Test Site, Nevada: U.S. Geological Survey Open-File Report 80-1098, $27 \mathrm{p}$.

Faunt, C.C., D'Agnese, F.A., and Turner, A.K., in press, Hydrogeologic map of the Death Valley region, Nevada and California developed using GIS techniques: U.S. Geological Survey WaterResources Investigations Report 95-4016.

Fiero, G.W., Jr., Illian, J.R., Dinwiddie, G.A., and Schroder, L.J., 1974, Use of hydrochemistry for interpreting ground-water flow systems in central Nevada: U.S. Geological Survey Report 474-178, $44 \mathrm{p}$.

Fitzpatrick, John, 1962, Biaxial device for determining the elasticity of stress-relief cores: U.S. Bureau of Mines Report of Investigation 6128, 13 p.

Fridrich, C.J., Dudley, W.W., Jr., and Stuckless, J.S., 1994, Hydrogeologic analysis of the saturated-zone groundwater system under Yucca Mountain, Nevada: Journal of Hydrology, v. 154, nos. 1-4, p. 133-168.

Frizzel, V.A., and Shulters, Jacqueline, 1990, Geologic map of the Nevada Test Site, southern Nevada: U.S. Geological Survey Miscellaneous Investigations Series Map I-2046, scale 1:100,000, 1 sheet.

Frizzel, V.A., and Zoback, M.L., 1987, Stress orientation determined from fault slip data in Hampel Wash area, Nevada, and its relation to contemporary regional stress field: Tectonics, v. 6, p. 89-98.
Galloway, Devin, 1993, Earth-tide induced fluid-pressure changes in Devils Hole, Death Valley National Monument, California-Nevada: San Francisco, Calif., American Geophysical Union Abstracts 1993 Annual Fall Meeting, p. 565.

Grose, T.L., 1983, Thirty-two geologic cross-sections, Clark, Esmeralda, Lincoln, Mineral and Nye Counties, Nevada and adjacent areas in California: Nevada Bureau of Mines and Geology Open-File Report 83-13.

Grose, T.L., and Smith, G.I., 1989, Geology, in Bedinger, M.S., Sargent, K.A., and Langer, W.H., eds., Studies of geology and hydrology in the Basin and Range Province, southwestern United States, for isolation of high-level radioactive waste: U.S. Geological Survey Professional Paper 1370-F, p. 5-19.

Haimson, B.C., Lacomb, J., Jones, A.H., and Green, S.J., 1974, Deep stress measurements in tuff at the Nevada Test Site, in Advances in Rock Mechanics, v. IIa, p. 557-561.

Hamilton, W.B., 1988, Detachment faulting in the Death Valley region, California and Nevada, in Carr, M.D., and Yount, J.C., eds., Geologic and hydrologic investigations of a potential nuclear waste disposal site at Yucca Mountain, southern Nevada: U.S. Geological Survey Bulletin 1790, p. 51-86.

Harmsen, S.C., 1991, Seismicity and focal mechanisms for the southern Great Basin of Nevada and California in 1990: U.S. Geological Survey Open-File Report 91-367, 103 p.

Harmsen, S.C., and Bufe, C.G., 1991, Seismicity and focal mechanisms for the southern Great Basin of Nevada and California -1987 through 1989: U.S. Geological Survey Open-File Report 91-572, 208 p.

Hildenbrand, T.G., Rogers, A.M., Oliver, H.W., Harmsen, S.C., Nakata, J.K., Aitken, D.S., Harris, R.N., and Carr, M.D., 1988, Regional geologic and geophysical maps of the southern Great Basin, in Carr, M.D., and Yount, J.C., eds., Geologic and hydrologic investigations of a potential nuclear waste disposal site at Yucca Mountain, southern Nevada: U.S. Geological Survey Bulletin 1790, p. 3-22.

Hill, R.L., and Beeby, D.J., 1977, Surface faulting associated with the 5.2 magnitude Galway Lake earthquake of May 31, 1975-Mojave Desert, San Bernardino County, California: Geological Society of America Bulletin, v. 88, p. 1378-1384.

Hollett, K.J., Danskin, W.R., McCaffrey, W.F., and Walti, C.L., 1991, Geology and Water Resources of Owens Valley, California: U.S. Geological Survey Water-Supply Paper 2370-B, 77 p. 
Hunt, C.B., and Mabey, D.R., 1966, Stratigraphy and structure, Death Valley, California: U.S. Geological Survey Professional Paper 494-A, 1 pl., 162 p.

Hunt, C.B., and Robison, T.W., 1960, Possible interbasin circulation of ground water in the southern part of the Great Basin: U.S. Geological Survey Professional Paper 400-B, p. B273-B274.

Hunt, C.B., Robinson, T.W., Bowles, W.A., and Washburn, A.L., 1966, Hydrologic basin, Death Valley, California: U.S. Geological Survey Professional Paper 494-B, 138 p.

Jennings, C.W., 1961, Geologic map of California-Kingman sheet: California Division of Mines and Geology, scale $1: 250,000,1$ sheet.

Jennings, C.W., Burnett, J.L., and Troxel, B.W., 1962, Geologic map of California-Trona sheet: California Division of Mines and Geology, scale 1:250,000, 1 sheet.

Lattman, L.H., and Parizek, R.R., 1964, Relationship between fracture traces and the occurrence of groundwater in carbonate rocks: Journal of Hydrology, v. 2, no. 2, p. 73-91.

Lock, Augustus, Billingsley, P.R., and Mayo, E.B., 1940, Sierra Nevada tectonic patterns: Geological Society of America Bulletin, v. 51, p. 513-540.

Longwell, C.R., 1960, Possible explanation of diverse structural patterns in southern Nevada: American Journal of Science, v. 258-A, p. 192-203.

Maldonado, Florian, and Hausback, B.P., 1990, Geologic map of the northeast quarter of the Bullfrog Quadrangle, Nye County, Nevada: U.S. Geological Survey Miscellaneous Investigations Series Map I-2049, scale 1:24,000, 1 sheet.

Maxey, G.B., 1968, Hydrogeology of desert basins: Ground Water, v. 6 , no. 5 , p. 10-22.

McAllister, J.F., 1970, Geology of the Furnace Creek borate area, Death Valley, Inyo County, California: California Division of Mines and Geology Map Sheet 14 , scale 1:24,000, 1 sheet. 1971, Preliminary geologic map of Funeral Mountains in the Ryan quadrangle, Death Valley region, Inyo County, California: U.S. Geological Survey Open-File Map, scale 1:62,500, 1 sheet.

1973, Geologic map and sections of the Amargosa

Valley borate area-southeast continuation of the Furnace Creek Area-Inyo County, California: U.S. Geological Survey Miscellaneous Investigations Series Map I-782, scale 1:24,000, 1 sheet.

McKenzie, D.P., 1969, The relation between fault plane solutions for earthquakes and the directions of the principal stresses: Bulletin of the Seismological Society of America, v. 59, p. 591-601.
Mifflin, M.D., 1988, Region 5, Great Basin, in Back, William, Rosenshein, J.S., and Seaber, P.R., eds., Hydrogeology: Boulder, Colo., Geological Society of America, The Geology of North America, v. O-2, p. 69-78.

Noble, D.C., and Christiansen, R.L., 1968, Geologic map of the southwest quarter of the Black Mountain Quadrangle, Nye County, Nevada: U.S. Geological Survey Miscellaneous Investigations Series Map I-562, scale 1:24,000, 1 sheet.

Orkild, P.P., Sargent, K.A., and Snyder, R.P., 1969, Geologic map of Pahute Mesa, Nevada Test Site and Vicinity, Nye County, Nevada: U.S. Geological Survey Miscellaneous Investigations Series Map I-754, scale $1: 48,000,1$ sheet.

Peter, K.D., Kolm, K.E., Downey, J.S., and Nichols, T.C., 1988, Lineaments, significance, criteria for determination and varied effects on ground-water systemsA case history in the use of remote sensing, in Johnson, A.I., and Patterson, C.B., eds., Geotechnical applications of remote sensing and remote data transmission: American Society for Testing and Materials, ASTM STP 967, p. 46-68.

Peterson, F.F., 1981, Landforms of the Basin and Range Province defined for soil survey: Nevada Agricultural Bulletin No. 28, Max C. Fleischmann College of Agriculture, Reno, University of Nevada, $53 \mathrm{p}$.

Plume, R.W., and Carlton, S.M., 1988, Hydrogeology of the Great Basin region of Nevada, Utah, and adjacent states: U.S. Geological Survey Hydrologic Investigations Report 694-A, 1 sheet.

Reheis, M.C., 1990, Aerial photographic interpretation of lineaments and faults in late Cenozoic deposits in the eastern parts of the Saline Valley 1:100,000 quadrangle, Nevada and California, and the Darwin Hills 1:100,000 quadrangle, California: U.S. Geological Survey Open-File Report 90-500, 6 p.

Reheis, M.C., and Noller, J.S., 1990, Aerial photographic interpretation of lineaments and faults in late Cenozoic deposits in the eastern part of the Benton Range 1:100,000 quadrangle and the Goldfield, Last Chance Range, Beatty, and Death Valley Junction 1:100,000 quadrangle, Nevada and California: U.S. Geological Survey Open-File Report 90-41, 9 p.

Reynolds, M.W., 1974, Recurrent middle and late Cenozoic deformation, north-eastern Death Valley, CaliforniaNevada: Geological Society of America Abstracts with Programs (Cordilleran Section), v. 3, no. 2, p. $182-183$.

Rice, W.A., 1984, Preliminary two-dimensional regional hydrological model of the Nevada Test Site and vicinity: SAND83-7466, Pacific Northwest Laboratory, Richland, Wash., 44 p. 
Rogers, C.L., Ekren, D.C., Noble, D.C., and Weir, J.E., 1968, Geologic map of the northern half of the Black Mountain Quadrangle, Nye County, Nevada: U.S. Geological Survey Miscellaneous Investigations Series Map I-545, scale 1:62,500, 1 sheet.

Rogers, A.M., Harmsen, S.C., Carr, W.J., and Spence, W., 1983, Southern Great Basin Seismological Data Report for 1981 and Preliminary Data Analysis: U.S. Geological Survey Open-File Report 83-669, 239 p.

Rogers, A.M., Harmsen, S.C., and Meremonte, M.E., 1987, Evaluation of the seismicity of the southern Great Basin and its relationship to the tectonic framework of the region: U.S. Geological Survey Open-File Report 87-408, $196 \mathrm{p}$.

Rojstaczer, Stuart, 1987, The local effects of groundwater pumpage within a fault-induced groundwater basin, Ash Meadows, Nye County, Nevada, U.S.A.: Journal of Hydrology, v. 91, p. 319-337.

Sargent, K.A., and Orkild, P.P., 1973, Geologic map of Wheelbarrow Peak-Rainier Mesa area, Nye County, Nevada: U.S. Geological Survey Miscellaneous Investigations Series Map I-567, scale 1:48,000, 1 sheet.

Smith, R.B., and Lindh, A.G., 1978, Fault-plane solutions of the Western United States-A compilation: Geological Society of America Memoir 152, p. 107-109.

Smith, R.B., and Sbar, M.L., 1974, Contemporary tectonics and seismicity of the western United States with emphasis on the intermountain seismic belt: Geological Society of America Bulletin, v. 85, p. 1205-1218.

Soller, D.R., Stettner, W.R., Lanfear, K.J., and Aitken, D.S., 1990, A user's manual for a method of map scanning and digital editing for thematic map production and data-base construction: U.S. Geological Survey Circular 1054, $38 \mathrm{p}$.

Stewart, J.H., 1971, Basin and range structure-A system of horsts and grabens produced by steep-sided extension: Geological Society of America Bulletin, v. 82 , p. $1019-1044$.

-1978, Basin and range structure in North AmericaA review, in Smith, R.B., and Eaton, G.P., eds., Cenozoic tectonics and regional geophysics in the western Cordillera: Geological Society of America Memoir 152, p. 1-31.

Stewart, J.H., and Carlson, J.E., 1978, Geologic map of Nevada: U.S. Geological Survey Map, scale $1: 500,000,2$ sheets.

Stock, J.M., Healy, J.H., Svitek, J., and Mastin, L., 1986, Report on televiewer log and stress measurements in holes USW G-3 and UE-25p1, Yucca Mountain, Nye County, Nevada: U.S. Geological Survey Open-File Report 86-369, $39 \mathrm{p}$.

Strand, R.G., 1967, Geologic map of California-Mariposa sheet: California Division of Mines and Geology, scale 1:250,000, 1 sheet.
Streitz, Robert, and Stinson, M.C., 1974, Geologic map of California-Death Valley sheet: California Division of Mines and Geology, scale 1:250,000, 1 sheet.

Swadley, W.C., and Carr, W.J., 1987, Geologic map of the Quaternary and Tertiary deposits of the Big Dune quadrangle, Nevada-California: U.S. Geological Survey Miscellaneous Investigations Series Map I-1767, scale 1:48,000, 1 sheet.

Troxel, B.W., and Wright, L.A., 1989, Geologic map of the central and northern Funeral Mountains and adjacent areas, Death Valley region, southern California: U.S. Geological Survey Open-File Report 89-348, scale 1:62,500, 1 sheet.

Từner, R.M., and Bawiec, W.J., 1991, Digital geologic coverage of Nevada - A digital representation of the 1978 geologic map of Nevada: U.S. Geological Survey Digital Data Series 2.

U.S. Geological Survey, 1989, Digital line graphs frorn 1:100,000 scale maps: U.S. Geodata Data User's Guide 2, $88 \mathrm{p}$.

Waddell, R.K., 1982, Two-dimensional, steady-state model of ground-water flow, Nevada Test Site and vicinity, Nevada-California: U.S. Geological Survey WaterResources Investigations Report 82-4085, $77 \mathrm{p}$.

Warren, W.E., and Smith, C.W., 1985, In-situ stress estimates from hydraulic fracturing and direct observation of crack orientation: Journal of Geophysical Research, v. 90 , no. B8, p. 6829-6839.

Weaver, C.S., and Hill, D.P., 1979, Earthquake swarms and local crustal spreading along major strike-slip faults in California: Pageoph, v. 117, p. 51-64.

Winograd, I.J., and Pearson, F.J., Jr., 1976, Major carbon-14 anomaly in a regional carbonate aquifer-Possible evidence for mega scale channeling, south-central Great Basin: Water Resources Research, v. 12, no. 6, p. 1125-1143.

Winograd, I.J., and Thordarson, William, 1975, Hydrologic and hydrochemical framework, south-central Great Basin, Nevada-California, with special reference to the Nevada Test Site: U.S. Geological Survey Professional Paper 712C, p. C1-C126.

Wright, Lauren, 1976, Late Cenozoic fault patterns and stress fields in the Great Basin and westward displacement of the Sierra Nevada block: Geology v. 4, p. 489-494.

Zoback, M.L., and Zoback, M.D., 1980a, Faulting patterns in north-central Nevada and strength of the crust: Journal Geophysical Research, v. 85, no. B1, p. 275-284.

$-1980 \mathrm{~b}$, State of stress in the conterminous United States: Journal Geophysical Research, v. 85, no. B11, p. 6113-6156. 
Page(s) size did not permit electronic reproduction. Information may be purchased by the general public from the National Technical Information Service, U.S. Department of Commerce, Springfield, VA 22161 (Area Code 703-487-4650). DOE and DOE contractors may purchase information by contacting DOE's Office of Scientific and Technical Information, P.O. Box 62, Oak Ridge, TN 37831, Attn: Information Services (Area Code 423-576-8401). 